Cayque Monteiro de Castro Nascimento

Propriedades Reológicas Interfaciais de Modelos de Surfactante Pulmonar.

Dissertação de Mestrado

Dissertação apresentada ao Programa de Pós-graduação em Química da PUC-Rio como requisito parcial para obtenção do grau de Mestre em Química.

Orientador: Prof. Dr. André Silva Pimentel Coorientador: Prof. Dr. Luciano Caseli

Rio de Janeiro Março de 2021 


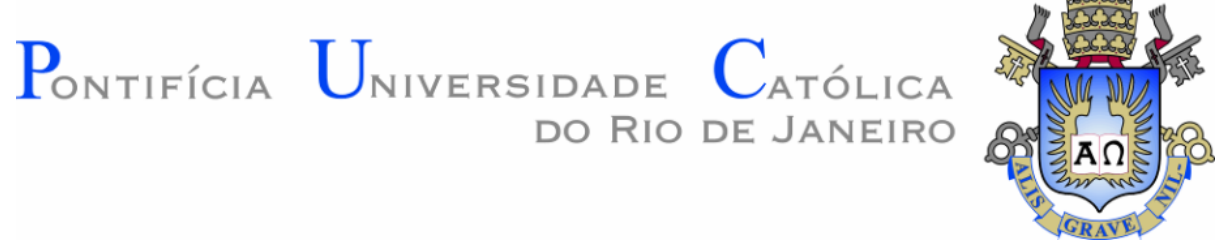

Cayque Monteiro de Castro Nascimento

\section{Propriedades Reológicas Interfaciais de Modelos de Surfactante Pulmonar.}

Dissertação apresentada ao Programa de Pós-graduação em Química da PUC-Rio como requisito parcial para obtenção do grau de Mestre em Química. Aprovada pela Comissão Examinadora abaixo.

Prof. Dr. André Silva Pimentel

Orientador

Departamento de Química - PUC-Rio

Prof. Dr. Luciano Caseli

Coorientador

Departamento de Química - Unifesp

Prof. Dr. Paulo Henrique de Souza Picciani Instituto de Macromoléculas - UFRJ

Prof. Dr. Paulo Roberto de Souza Mendes Departamento de Engenharia Mecânica - PUC-Rio

Dra. Roberta Kamei

Grupo de Reologia - PUC-Rio 
Todos os direitos reservados. É proibida a reprodução total ou parcial do trabalho sem autorização da universidade, do autor e do orientador.

\section{Cayque Monteiro de Castro Nascimento}

Graduou-se em Licenciatura em Química pela Universidade Federal do Rio de Janeiro (UFRJ) em 2018. Atua na área de Físico-

Química, com ênfase em reologia interfacial.

Ficha Catalográfica

Nascimento, Cayque Monteiro de Castro

Propriedades Reológicas Interfaciais de Modelos de Surfactante Pulmonar / Cayque Monteiro de Castro Nascimento; Orientador: André Silva Pimentel; Coorientador: Luciano Caseli. - 2021. 86 f. : il. color. ; $30 \mathrm{~cm}$

Dissertação (mestrado) - Pontifícia Universidade Católica do Rio de Janeiro, Departamento de Química, 2021.

Inclui bibliografia

1. Química - Teses. 2. Surfactante Pulmonar. 3. Propriedades reológicas. 4. Reômetro de Cisalhamento Interfacial. 5. Tensiômetro de Gota. I. Pimentel, André Silva. II. Caseli, Luciano. III. Pontifícia Universidade Católica do Rio de Janeiro. Departamento de Química. IV. Propriedades Reológicas Interfaciais de Modelos de Surfactantes Pulmonares. 
A Deus, por estar comigo em todos os momentos.

A minha família, pelo apoio incondicional. Ao professor André, por sua extrema dedicação, paciência e companheirismo. Ao professor Luciano, por toda a ajuda e troca de conhecimento. 


\section{Agradecimentos}

Agradeço primeiramente a Deus, por me proporcionar mais uma conquista.

A minha família, por todo amor e paciência.

Ao meu orientador, professor André, por ter me acolhido no momento em que mais me senti perdido na instituição.

Ao meu Coorientador, professor Luciano Caseli, por abrir as portas de seu laboratório e me ajudar nesta jornada.

Ao Grupo de Reologia da PUC-Rio, em especial a Isabela, por dedicar parte de seu tempo em me ajudar.

Aos colegas de laboratório, especialmente ao Lucas, Felipe e Francesca, pelo apoio e troca de conhecimento.

A banca examinadora, por dedicar parte de seu precioso tempo para contribuir com este trabalho.

Ao Departamento de Química da PUC - Rio, por todas as oportunidades que pude vivenciar nesta universidade tão conceituada.

A CAPES, CNPq, FAPERJ, INCT-FCx e PUC-Rio pelo auxílio concedido para a realização deste trabalho.

Ao Laboratório de Fluidos Complexos da PUC-Rio, por ser minha base acolhedora.

O presente trabalho foi realizado com apoio da Coordenação de Aperfeiçoamento de Pessoal de Nível Superior - Brasil (CAPES) - Código de Financiamento 001. 


\section{Resumo}

Nascimento, Cayque Monteiro de Castro; Pimentel, André Silva. Propriedades Reológicas Interfaciais de Modelos de Surfactante Pulmonar. Rio de Janeiro, 2021. 86 p. Dissertação de Mestrado - Departamento de Química, Pontifícia Universidade Católica do Rio de Janeiro.

As propriedades reológicas na interface ar/água de modelos de surfactantes pulmonares (DPPC, DPPC:DPPG, DPPC:DPPG:Colesterol, Survanta e Curosurf) foram investigadas utilizando técnicas de cisalhamento superficiais (reometria de cisalhamento interfacial) e dilatacionais (tensiometria da gota pendente). Assim, alguns parâmetros de interesse foram obtidos para 0 estudo da viscoelasticidade das amostras (como viscosidade e módulos de armazenamento e perda) e as limitações das técnicas também foram analisadas. Os experimentos foram realizados de forma dinâmica, em que a faixa de frequência de interesse abrange, inclusive, a frequência respiratória de um atleta. Os resultados obtidos mostram a maior viscosidade do Survanta, frente ao Curosurf, e mostram o caráter intermediário do DPPC, que pode ser alterado pela adição de DPPG (aumentando a elasticidade) e Colesterol (aumentando a viscosidade), sugerindo que a mistura DPPC:DPPG pode ser mais adequada do que com DPPC:DPPG:COL para simular o comportamento do surfactante pulmonar. A reometria dilatacional não se mostrou aplicável ao estudo dos surfactantes, o que pode ser causado pela alta viscoelasticidade e relativa instabilidade do Survanta.

\section{Palavras - Chave}

Surfactante pulmonar; Propriedades reológicas; Reômetro de cisalhamento interfacial; Tensiômetro de gota. 


\section{Abstract}

Nascimento, Cayque Monteiro de Castro; Pimentel, André Silva. Interfacial Rheological Properties of Lung Surfactant Models. Rio de Janeiro, 2021. 86 p. Dissertação de Mestrado - Departamento de Química, Pontifícia Universidade Católica do Rio de Janeiro.

The interfacial rheological properties of lung surfactants models (DPPC, DPPC:DPPG, DPPC:DPPG:Cholesterol, Survanta and Curosurf) at the air/water interface were investigated using shear (interfacial shear rheometry) and dilatacional (pendent drop tensiometry) techniques. Thus, some parameters of interest were obtained to study the viscoelasticity of the samples (such as viscosity and storage and loss modules) and the limitations of the techniques were also analyzed. The experiments were carried out dynamically, in which the interest frequency range includes the respiratory rate of an athlete. The results obtained show the higher viscosity of Survanta, compared to Curosurf, and show the intermediate character of DPPC, which can be altered by addition of DPPG (increasing the elasticity) and Cholesterol (increasing the viscosity), suggesting the DPPC:DPPG mixture may be more suitable than with DPPC:DPPG:CHOL to simulate the lung surfactant behavior. The dilatacional rheometry does not shown to be applicable for surfactants studies, which can be caused by the high viscoelasticity and relative instability of Survanta.

\section{Keywords}

Lung surfactants; Rheological properties; Interfacial Shear Rheometer; Drop Tensiometer. 


\section{Sumário}

1 Introdução 16

2 Objetivos $\quad 21$

$2.1 \quad$ Objetivos Gerais 21

$\begin{array}{lll}2.2 & \text { Objetivos Específicos } & 21\end{array}$

$3 \quad$ Referencial Teórico 22

$\begin{array}{lll}\text { 3.1 Surfactantes Pulmonares } & 22\end{array}$

3.2 Reologia e Propriedades Reológicas 34

3.3 Reômetro de Cisalhamento Interfacial 45

3.4 Tensiômetro de Gota 50

$4 \quad$ Metodologia 52

4.1 Reologia de Cisalhamento 52

$\begin{array}{lll}4.2 & \text { Reologia Dilatacional } & 55\end{array}$

5 Resultados e Discussões 56

5.1 Valores de G' e G” em função da frequência 56

5.2 O Módulo Dinâmico e o Regime Viscoelástico 62

5.3 Valores de tan $\delta$ em função da frequência 65

5.4 Determinação da viscosidade complexa $\left(\eta^{*}\right)$

$\begin{array}{lll}5.5 & \text { Reologia Dilatacional } & 71\end{array}$

6 Conclusões $\quad 75$

$\begin{array}{lll}7 & \text { Perspectivas Futuras } & 77\end{array}$

$8 \quad$ Referências $\quad 78$ 


\section{Lista de Figuras}

Figura 1: llustração do alvéolo pulmonar

Figura 2: Representação das estruturas do DPPC, DPPG e 25 Colesterol

Figura 3: llustrações dos alvéolos pulmonares de diferentes tamanho e pressões: instável e estável

Figura 4: Fases da monocamada de surfactante pulmonar

Figura 5: Comportamento das moléculas em uma monocamada

Figura 6: Alteração de pressão no ciclo respiratório

Figura 7: Relação entre $\sigma$ e $\dot{\gamma}$

Figura 8: Variação de $\eta$ em função de z

Figura 9: Representação da reformação dilatacional e de cisalhamento

Figura 10: Imagem microscópica processada da haste na interface e gráfico da posição da haste em função do tempo

Figura 11: Representação dos componentes do ISR

Figura 12: llustração do método da Placa de Wilhelmy

Figura 13: Teclis ${ }^{\circledR}$ acoplado ao software Windrop

Figura 14: Interface do Windrop no tratamento dos dados obtidos

Figura 15: Representação esquemática do experimento 


\section{Lista de Tabelas}

Tabela 1: Composição dos surfactantes pulmonares em quantidades relativas em percentual

Tabela 2: Indicação da frequência respiratória normal (em respirações por minuto) de acordo com a faixa etária do ser humano

Tabela 3: Relação entre tan $\delta$ e os comportamentos do filme

Tabela 4: Valores de G' e G" na interface ar-água de uma solução de 56 Ca2+ 1,63.10-3 mol.L-1

Tabela 5: G' e G" para as misturas de DPPC:DPPG (70:30) e DPPC: 60 DPPG:COL (70:20:10)

Tabela 6: Módulo dinâmico interfacial das misturas de DPPC:DPPG com e sem colesterol. Os valores apresentam-se no Regime Viscoelástico Linear trazendo confiabilidade e sentido físico para nossos resultados.

Tabela 7: $\tan \delta$ das amostras de DPPC:DPPG com e sem colesterol 


\section{Lista de Gráficos}

Gráfico 1: G' e G" para a solução de $\mathrm{Ca}^{2+}$ de concentração $1,63.10^{-3} \mathrm{~mol} \mathrm{~L}^{-1}$ na interface ar/água

Gráfico 2: G' e G" do Survanta com nossos dados e da literatura

Gráfico 3: Valores de G' e G" do Curosurf. Sob baixas frequências, seus módulos elástico e viscoso são próximos.

Gráfico 4: G' e G" do DPPC com nossos dados e da literatura

Gráfico 5: Relação entre $\mathrm{G}$ da solução de $\mathrm{Ca} 2+$ e a frequência

Gráfico 6: Relação entre G do Curosurf e a frequência

Gráfico 7: Relação entre G do DPPC e a frequência, com nossos resultados e da literatura

Gráfico 8: Relação entre G do Survanta e a frequência, com 64 nossos

resultados e da literatura

Gráfico 9: $\tan \delta$ da solução de Ca2+, mostrando característica elástica ao longo de toda a frequência estudada

Gráfico 10: $\tan \delta$ do Curosurf, mostrando sua característica 66 elástica ao longo de toda faixa de frequência estudada

Gráfico 11: $\tan \delta$ do Survanta, mostrando sua característica 66 viscosa ao longo de toda a faixa de frequência estudada.

Gráfico 12: $\tan \delta$ do DPPC, mostrando sua mudança de 68 comportamento (viscoso para elástico) com o aumento da frequência

Gráfico 13: Viscosidade complexa do Survanta ao longo da frequência de interesse, com nossos dados e da literatura

Gráfico 14: Viscosidade complexa do Curosurf

Gráfico 15: Viscosidade complexa do DPPC, com nossos dados e da literatura 
Gráfico 16: Viscosidade complexa das misturas de DPPC:DPPG (70:30) e DPPC:DPPG:Colesterol (70:20:10)

Gráfico 17: Valores de E' e E" do Survanta, com dados estáveis 73 na interface ar/água e apresentando característica elástica e valores de $\mathrm{E}$ do Survanta relativamente estáveis em função do tempo na interface ar/água

Gráfico 18: $\tan \delta$ do Survanta na análise reológica dilatacional 73 mostrando seu comportamento elástico

Gráfico 19: Valores de E' e E" para Curosurf sob frequências 0,1 74 e $0,5 \mathrm{~Hz}$. Sob a frequência maior, nota-se maior estabilidade do Curosurf, que possuía variação de volume mais rápida. Não foram obtidos valores muito discrepantes entre tais frequências

Gráfico 20: Módulo dilatacional do Curosurf em função do tempo sob frequências de 0,1 e $0,5 \mathrm{~Hz}$. Após formada a gota, esperouse 1 minuto para as medições e sob a frequência maior, $E$ mostrou-se mais estável

Gráfico 21: $\tan \delta$ do Curosurf na reologia dilatacional, sob 75 frequências de 0,1 e $0,5 \mathrm{~Hz}$ 


\section{Lista de Siglas e Abreviaturas dos Fosfolipídios}

ABNT - Associação Brasileira de Normas Técnicas

BLES - Surfactante de extrato de pulmão bovino

BNS - Surfactante natural bovino

Covid-19 - Corona Virus Disease (2019)

DPPC - 1,2-dipalmitoil-sn-glicero-3-fosfatidilcolina

DPPE - 1,2-dipalmitoil-sn-glicero-3-fosfatidiletanolamina

DPPG - 1,2-dipalmitoil-sn-3-glicero-[fosfo-rac-(1-glicerol)]

DPPI - 1,2-dipalmitoil-sn-glicero-3-fosfatidilinositol

DPPS - 1,2-dipalmitoil-sn-glicero-3-fosfatidilserina

E - Módulo interfacial dilatacional

E' - Módulo interfacial dilatacional elástico

E" - Módulo interfacial dilatacional viscoso

G - Módulo interfacial de cisalhamento

G'- Módulo interfacial de cisalhamento elástico

G"- Módulo interfacial de cisalhamento viscoso

ISR - Reômetro de Cisalhamento Interfacial

LC - Líquido condensado

LE - Líquido estendido

LO - Líquido ordenado

POPG - 1-palmitoil-2-oleoil-sn-glicero-3-fosfo(1-rac-glicerol)

RVL - Regime Viscoelástico Linear

SARN - Síndrome da angústia respiratória neonatal

SDR - Síndrome do desconforto respiratório

SP-A - Proteína surfactante A

SP-B - Proteína surfactante $B$

SP-C - Proteína surfactante $C$

SP-D - Proteína surfactante $D$

$\sigma-$ Tensão de Cisalhamento

$\dot{\gamma}$ - Taxa de Cisalhamento

$\eta$ - Viscosidade 
$\eta^{*}$ - Viscosidade complexa

$\eta$ ' - Viscosidade fora de fase

v - Viscosidade cinemática

$\eta_{0}$ - Viscosidade de cisalhamento zero

$\eta s$ - Viscosidade superficial 
"Existe algum conflito entre a ciência e religião? Não há conflito na mente de Deus, mas muitas vezes há conflito na mente dos homens." Henry Eyring

"A meu ver, jamais se encontrará uma verdadeira contradição entre a fé e a ciência." Robert Andrews Millikan 


\section{Introdução}

Nos alvéolos pulmonares de animais e seres humanos, células de pneumócitos do tipo II produzem uma mistura lipoprotéica de fundamental importância conhecida como surfactante pulmonar. Composta em sua maioria por fosfolipídios, principalmente por dipalmitoilfosfatidilcolina (DPPC), essa mistura auxilia o processo de respiração reduzindo a tensão superficial dos alvéolos para valores próximos de zero. O surfactante pulmonar é produzido naturalmente pelo bebê próximo das 32 semanas de gestação até alcançar a quantidade suficiente para que o pulmão consiga efetuar as trocas gasosas quando alcança a maturação pulmonar (BAER et al., 2019)

Quando bebês nascem prematuros, seus pulmões ficam debilitados devido à falta ou produção insuficiente deste tensoativo, acometendo os bebês com síndrome da angústia respiratória neonatal (SARN) ou síndrome do desconforto respiratório (SDR) do recém-nascido. Com esta insuficiência, os alvéolos requerem um esforço respiratório grande para voltarem a inflar após a liberação de gás carbônico, correndo o risco do colabamento pulmonar. Procedimentos de rotina de hospitais incluem a aplicação de surfactantes pulmonares exógenos no recém-nascido e estudos comprovam sua aplicabilidade e eficiência (RAMANATHAN et al., 2004).

Estudos indicam que há cerca de 15 milhões de nascimentos prematuros no mundo por ano, com cerca de 4 milhões de mortes (LAWN et al., 2004), sendo esta a principal causa de mortalidade em crianças de até os cinco anos de idade (LIU et al., 2016). O Brasil ocupa a 10ª posição no ranking de nascimentos prematuros, com cerca de $300 \mathrm{mil}$ ao ano (12\% do total) e $12 \mathrm{mil}$ mortes, sendo os problemas respiratórios a principal causa que leva ao óbito, à frente dos problemas cardíacos, neurológicos e problemas relacionados ao baixo peso (BLENCOWE et al., 2012). Os índices de mortalidade neonatal na América Latina podem ser até quatro vezes maior do que nos países europeus e norte americanos (CARRERA; CABERO; BARAIBAR, 2001; JM; CABERO; BARAIBAR $R, 2001)$. Com estes índices significativos, os surfactantes pulmonares passaram a ser mais explorados e desenvolvidos especialmente a 
partir da década de $70 \mathrm{com}$ o objetivo de assemelhar-se ao surfactante endógeno (ENHÖRNING; ROBERTSON, 1972) e, a partir da década de 90, modelos comerciais passaram a ser disponibilizados para uso clínico (FREDDI, N. A; FILHO, J, O; FIORI, H, 2003).

Curosurf e Survanta são suspensões estéreis comerciais extraídos por lavagens de tecido pulmonar porcino e bovino picado, respectivamente. $O$ Curosurf é ainda purificado por diferentes etapas cromatográficas, para remover o colesterol e outros lipídios neutros, enquanto o Survanta é suplementado com quantidades adicionais de DPPC, ácido palmítico e tripalmitoilglicerol. Os dois últimos aditivos contribuem para os níveis mais altos de ácidos graxos livres e triglicerídeos encontrados no Survanta em relação ao surfactante pulmonar natural. Além disso, devido à extração com acetato de etila, o teor de colesterol no Survanta é significativamente menor do que o do surfactante pulmonar natural. Apesar das diferenças na composição lipídica, também existem diferenças na composição proteica entre Curosurf e Survanta, que podem estar relacionadas a alguns aspectos inexplorados de sua complexidade multilamelar e que também podem conduzir a diferenças significativas em suas propriedades reológicas. Além destes modelos, o próprio DPPC é um modelo mais simples de surfactante pulmonar devido às suas características reológicas, tensoativas e seu teor nestes surfactantes. Outros modelos existentes são as misturas DPPC:DPPG (70:30) e DPPC:DPPG:Colesterol (70:20:10), que representam a composição lipídica majoritária no surfactante pulmonar, porém não refletem todos os aspectos de sua complexa composição (ROBERTSON; ENHÖRNING, 1974) (FILHO, P. L. O; GERBELLI, B. B., FORNASIER, F.; FILHO, A. B. C; YOSHINAGA, M. Y; MIYAMOTO, S; MORTARA, L; LACERDA, C. D; CUCCOVIA, I. M; PIMENTEL, A. S; OLIVEIRA, 2020).

Apesar de haver outros modelos disponíveis, como Infasurf, BLES e BNS, o alto custo comercial não os tornam acessíveis para a população em geral e também devido às regulações da agência nacional de vigilância sanitária (ANVISA) do Brasil, destacando-se o fato de não haver surfactante pulmonar comercial desenvolvido no Brasil, o que certamente o tornaria mais acessível. Para este desenvolvimento, torna-se fundamental um método de controle de qualidade de surfactantes para que suas propriedades reológicas possam ser medidas e analisadas. Não foi encontrado na Associação Brasileira de Normas 
Técnicas (ABNT) catálogo de normatizações sobre procedimentos para controle de qualidade de surfactantes pulmonares, ou seja, não foram encontrados estudos que sistematizassem processos de análises de propriedades reológicas de surfactantes pulmonares. Sem dúvidas, procedimentos reprodutíveis seriam importantes para estudos controlados e tornariam o conhecimento acessível para a sociedade. Este fato tornou-se uma das motivações deste trabalho.

O surfactante BLES $^{\circledR}$ nos últimos meses ganhou um enfoque especial devido a sua aplicação em pacientes com problemas respiratórios graves devido à pandemia do COVID-19, que pode reduzir a quantidade de ventilação necessária durante o tratamento desta doença (AHMED, S.; AKTER, MD. S.; ROY, K.; ISLAM, 2020; SCHLEGELMILCH, 2020; VELDHUIZEN, R. A. W.; ZUO, Y. Y.; PETERSEN, N. O.; LEWIS, J. F.; POSSMAYER, 2020). Também há estudos que indicam a melhora de pacientes com asma brônquica com a inalação de surfactante pulmonar sintético (PULMOLOGY, 2019).

As monocamadas de surfactantes pulmonares são formadas devido as suas propriedades anfifílicas. As propriedades mecânicas das monocamadas de modelos de surfactantes pulmonares podem ser estudadas na interface ar-água, fornecendo informações importantes sobre sua estabilidade estrutural e módulos de armazenamento e perda (BERNHARD et al., 2000). Propriedades importantes destas monocamadas podem ser obtidas através de análises do seu comportamento perante deformações, caracterizando a área da reologia.

A reologia é uma área da ciência que analisa as deformações da matéria quando provocada por uma tensão, isto é, uma força por unidade de área ou uma força por unidade de comprimento. Para um sólido, o foco do estudo está na alteração de sua forma, tamanho e/ou volume. Já para os fluidos, a taxa de deformação em função da tensão se torna mais importante. Análises reológicas contam com dois tipos de deformação: a deformação dilatacional, na qual ocorre com a expansão-compressão da interface a uma taxa constante, e a deformação de cisalhamento, que aplica tensões sobre o material causando deslocamento entre moléculas, mantendo a área interfacial constante (ZHANG; MATAR; CRASTER, 2002). Neste trabalho, os dois tipos de análises reológicas foram aplicados (dilatacional e de cisalhamento).

As propriedades reológicas em destaque neste trabalho são a viscosidade e a viscoelasticidade. Viscosidade é a medida de resistência interna de uma 
substância ao escoamento devido a uma força de atrito interna que surge entre as camadas adjacentes de fluido que estão em movimento relativo. Pode ser também entendido como o inverso da fluidez. Já a viscoelasticidade é propriedade dos materiais que apresentam características viscosas e elásticas ao sofrer deformação. Esta propriedade é comum entre os surfactantes pulmonares, que formam monocamadas das espécies ativas na interface arágua e estruturas nanométricas no meio aquoso tais como vesículas unilamelares e multilamelares (TADROS, 2005) (BAER et al., 2019).

$O$ estudo da reologia interfacial tem um papel importante na sociedade atual. No ramo alimentício, algumas proteínas são naturalmente ativas na superfície, o que significa que elas tendem a adsorver na interface, sendo, por isso, muito utilizadas na fabricação de espumas e emulsificantes. Na indústria, a medição da estabilidade de detergentes e espumas torna-se fundamental para controle de qualidade. Na produção de petróleo, emulsões estáveis água/óleo são formadas constantemente devido à presença de tensoativos. Assim, as propriedades reológicas interfaciais tornam-se fundamentais para 0 entendimento da viscoelasticidade e da estabilidade desses fluidos complexos (BENNET; MYERS, 1978; MORRIS, 2003).

O estudo da reologia de cisalhamento interfacial é importante também para caracterizar as monocamadas na interface ar-água. $\mathrm{O}$ assunto tem sido investigado especialmente a partir da década de 90 e o conhecimento adquirido sobre as propriedades reológicas de monocamadas estão em desenvolvimento. Instrumentos para essas medições têm sido desenvolvidos para fornecer informações sobre propriedades viscoelásticas, tais como o módulo de cisalhamento elástico, ou módulo de armazenamento, (G'), e módulo de cisalhamento viscoso, ou módulo de perda, (G") (BAILEY; WEIR, 1998).

Benmekbhi \& Sébastien (2013) investigaram a aplicabilidade do reômetro de cisalhamento interfacial (da sigla em inglês, ISR) e sugeriram que a técnica pode não ser adequada para medidas de propriedades reológicas de amostras de derivados de petróleo e surfactantes por não possuir sensibilidade adequada (BENMEKBHI; SÉBASTIEN, 2014). Hermans e colaboradores (2015) utilizaram a mesma técnica para determinar propriedades reológicas interfaciais de diferentes modelos de surfactantes pulmonares, mostrando que Survanta possui viscosidade superficial mais alta que outros surfactantes e que a técnica é 
adequada (HERMANS et al., 2015). Estes estudos são importantes para analisar modelos de surfactantes pulmonares na busca de possíveis divergências de informações encontradas na literatura quanto à eficácia do ISR. Tal fato também se tornou uma das motivações deste trabalho.

Na busca por informações rápidas e precisas sobre as propriedades de superfícies e de interfaces, os tensiômetros se tornaram grandes aliados nestes estudos de fluidos imiscíveis. Para as análises com deformações dilatacionais, o tensiômetro de gota se tornou largamente utilizado em análises de fluidos com variações de volume (IVANOVA, TZ.; MINKOV, I.; PANAIOTOV, I.; SAULNIER, P.; PROUST, 2004) (LI, J. B.; KRETZSCHMAR, G.; MILLER, R.; MOHWALD, 1999) (RAVERA, F; LOGLIO, G; KOVALCHUK, 2010).

A frequência utilizada nos experimentos é importante pois pode se relacionar à frequência respiratória à qual os alvéolos pulmonares estão submetidos, que varia conforme a idade nos serem humanos. Em geral, a média varia de 10 a 20 respirações por minuto nos idosos acima de 80 anos, 40 para recém-nascidos e pode chegar até 80 em atletas (GAZITÚA, 2014; LINDH, W, Q; POOLER, M; TAMPARO, C. D; DAHL, 2009; LIPPINCOTT WILLIAMS; WILKINS, 2006; RODRÍGUEZ-MOLINERO, A; NARVAIZA, L; RUIZ, J; GÁLVEZBARRÓN, 2013). Neste trabalho, estudou-se as propriedades reológicas dos surfactantes pulmonares sob frequências altas, inclusive, aquelas que se relacionam à frequência respiratória de um atleta em ação. Hermans e Vermant (2014) realizaram uma análise da reologia de cisalhamento interfacial do DPPC em frequências baixas em função da temperatura e da pressão da superfície, mostrando que a monocamada se comporta como um líquido viscoelástico (HERMANS; VERMANT, 2014). A principal diferença entre este trabalho e o nosso está na faixa de frequência que os experimentos foram realizados $(0,5 \mathrm{a}$ 2,0 Hz), mostrando sua originalidade e relevância pois não foram encontrados estudos de reologia interfacial de modelos de surfactantes pulmonares em altas frequências. 


\section{Objetivos}

\subsection{Objetivos Gerais}

O objetivo deste trabalho é investigar as propriedades reológicas de cisalhamento do DPPC, DPPC:DPPG (70:30), DPPC:DPPG:Colesterol (70:20:10), Survanta e Curosurf utilizando o reômetro de cisalhamento interfacial bem como as propriedades reológicas dilatacionais do Survanta e Curosurf utilizando o tensiômetro de gota pendente, bem como avaliar a aplicabilidade das técnicas quanto às suas limitações e sensibilidade.

\subsection{Objetivos Específicos}

- Determinar o módulo interfacial de cisalhamento, bem como os módulos elástico e viscoso, do DPPC, DPPC:DPPG (70:30), DPPC:DPPG:Colesterol (70:20:10), Survanta e Curosurf em função da frequência;

- Determinar o módulo interfacial dilatacional, bem como os módulos elástico e viscoso, do Survanta e Curosurf em função da frequência;

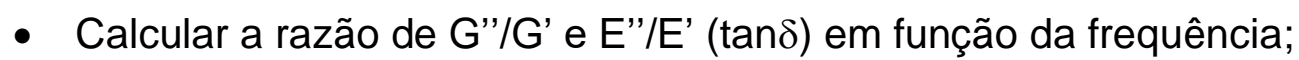

- Determinação da viscosidade superficial dos modelos de surfactantes pulmonares;

- Analisar a aplicabilidade do reômetro de cisalhamento interfacial e do tensiômetro de gota nas medições das propriedades viscoelásticas, nestas condições de trabalho, bem como investigar se há a sensibilidade adequada. 


\section{$3 \quad$ Referencial Teórico}

\subsection{Surfactantes Pulmonares}

Nos alvéolos pulmonares, células de pneumócitos tipo II são capazes de produzir o surfactante pulmonar, uma complexa mistura lipoprotéica de fundamental importância para a respiração por possuir características tensoativas. Estas características, devido à interação dos fosfolipídios com a água (principalmente), reduzem a tensão superficial dos alvéolos que possuem gotículas de água condensadas que cobrem o epitélio pulmonar, provenientes do ar atmosférico no momento da inspiração (HALLIDAY, 2008) (GEHR, 1978; WEIBEL, 1963). Assim, o alvéolo pulmonar no momento da inalação necessita de menor esforço (trabalho respiratório), evitando seu colapso. Uma representação de sua estrutura é mostrada na figura 1. Para entender a funcionalidade do surfactante pulmonar é necessário caracterizá-lo biofisicamente (SWABE et al., 1992).

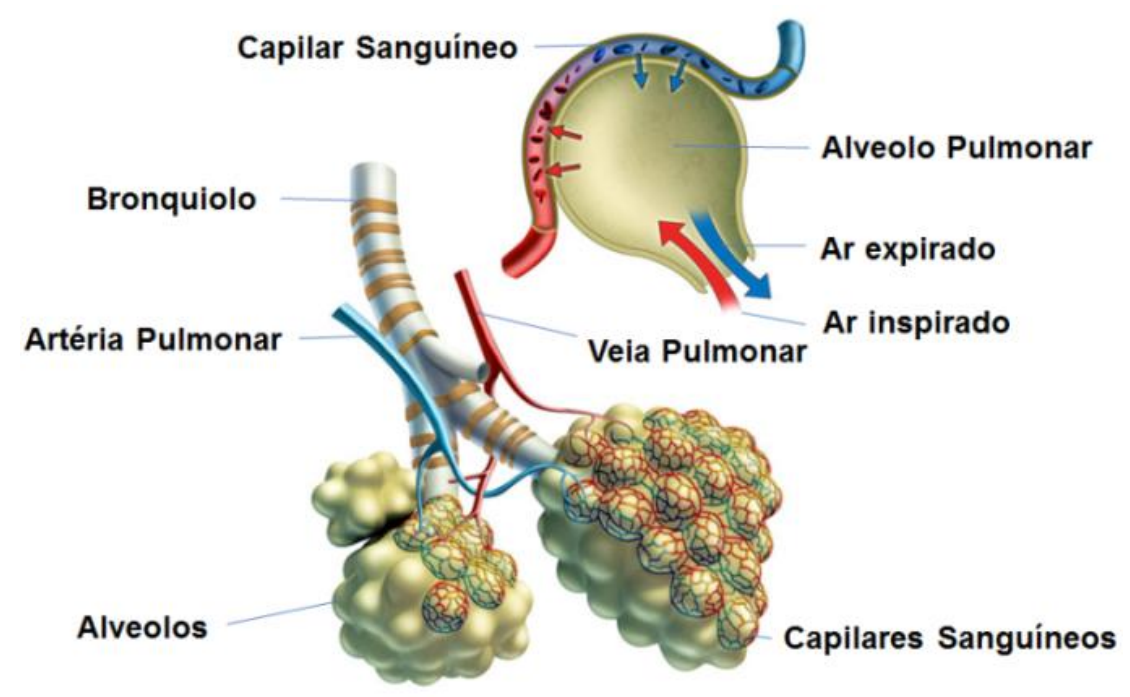

Figura 1: llustração do alvéolo pulmonar (EERP/USP, 2020). 
A tensoatividade, característica primária dos surfactantes pulmonares (do inglês surface active agent), influencia diretamente na redução da tensão superficial apresentada na interface ar-água dos alvéolos pulmonares. Uma molécula tensoativa apresenta sua estrutura dividida entre parte hidrofóbica (geralmente proveniente de cadeias hidrocarbônicas) e pela parte hidrofílica (formada por grupos fosfatos e o grupo colina, no caso do DPPC), responsável pela interação do tensoativo com água. Se a parte polar possuir cargas positivas, o surfactante é classificado como catiônico, caso contrário, ou seja, se possuir cargas negativas, será classificado como aniônico. Há também os surfactantes não iônicos, que apresentam grupos hidrofílicos sem carga ligados a cadeia hidrocarbônica, possuindo menos solubilidade em água. Um outro tipo é o surfactante anfótero, ou zwitteriônico, que possui um radical ácido e um básico. Esses tensoativos em solução aquosa possuem características catiônicas ou aniônicas dependentes do pH da solução (DALTIN, 2012) (WEIBEL, 1973).

O surfactante pulmonar é um fluido lipoproteico que forma uma monocamada de lipídios e proteínas surfactantes na interface ar-água, e estruturas unilamelares e multilamelares constituídas, de modo geral, por lipídios (80 a 90\% em massa) e proteínas surfactantes ( $5-10 \%$ em massa). Dentre a massa fosfolipídica, 70 a $80 \%$ é constituída de fosfatidilcolinas (PC), 5 a $10 \%$ de fosfatidilglicerol (PG) e o restante por outros fosfolipídios como fosfatidilnositol (PI), fosfatidiletanolamina (PE) e fosfatidilserina (PS) (RODRIGUEZ; PÉREZGIL, 2014). Colesterol e seus ésteres constituem menos de $5 \%$ da composição, mas possuem importância fundamental no aumento da fluidez das monocamadas e bicamadas lipoproteicas. $O$ espalhamento do filme é facilitado pelo DPPC, principalmente. As proteínas surfactantes SP-A, SP-B, SP-C e SPD fazem parte de sua composição, sendo SP-B e SP-C as principais responsáveis pelas propriedades biofísicas e funcionais dos surfactantes pulmonares. Já as proteínas surfactantes SP-A e SP-D fazem parte do sistema autoimune inato de defesa contra partículas estranhas ao pulmão (NAG et al., 1999). A estimativa da quantidade de surfactante pulmonar nos alvéolos é $4 \mathrm{mg} / \mathrm{kg}$ e diminui com a idade, mas não de maneira significativa (BAOUKINA; TIELEMAN, 2011). 
Os fosfolipídios são a base do surfactante pulmonar bem como de todas as membranas celulares, uma vez que sua estrutura contribui favoravelmente para a redução da tensão superficial na interface ar-água. Por serem moléculas anfipáticas, a porção polar é direcionada à fase aquosa, e a porção apolar direcionada para o ar. Desta forma, o contato entre a região hidrofóbica e as moléculas de água é minimizado (PARRA; PÉREZ-GIL, 2015). Apesar de uma quantidade pouco significativa, a presença de uma pequena quantidade de colesterol e proteínas no surfactante também é importante para seu funcionamento. A composição fosfolipídica do surfactante pulmonar permeia entre espécies saturadas e insaturadas. Essa coexistência é a base para a alta estabilidade dos filmes de surfactantes em altas taxas de compressão e para a fluidez e a dinâmica necessárias para as transformações estruturais ocorridas nas estruturas de monocamadas e bicamadas encontradas nos alvéolos (PÉREZ-GIL et al., 1992; PÉREZ-GIL; CASALS; MARSH, 1995).

Como espécie saturada, há principalmente o DPPC, de característica zwitteriônica, que possui uma grande capacidade de rigidez, empacotamento, rápida adsorção e espalhamento na interface, sendo o principal responsável pela redução da tensão superficial dos alvéolos pulmonares. Sua temperatura de transição de fase gel para fluido em bicamadas se dá em torno dos $41^{\circ} \mathrm{C}$, e, portanto, na temperatura corporal humana, seu estado é de gel cristalino em membranas que se apresentam como bicamadas, como membranas plasmáticas. Para as monocamadas alveolares, seu estado varia entre fluido e gel de acordo com o estado de compressão/expansão da membrana alveolar, conseguindo reduzir a tensão superficial dos alvéolos de 70 para $20 \mathrm{mN} \mathrm{m}^{-1}$. Outro fosfolipídio importante na composição do surfactante pulmonar é o DPPG, que acrescenta carga negativa ao fluido (REBELLO et al., 2002). A maior parte dos fosfolipídios insaturados é formada por POPG, que possui característica aniônica e temperatura de transição de fase perto dos $-2^{\circ} \mathrm{C}$ para bicamadas, atribuindo carga e fluidez ao surfactante (DE LA SERNA et al., 2012). Representações das estruturas do DPPC, DPPG e Colesterol são mostradas na Figura 2. 

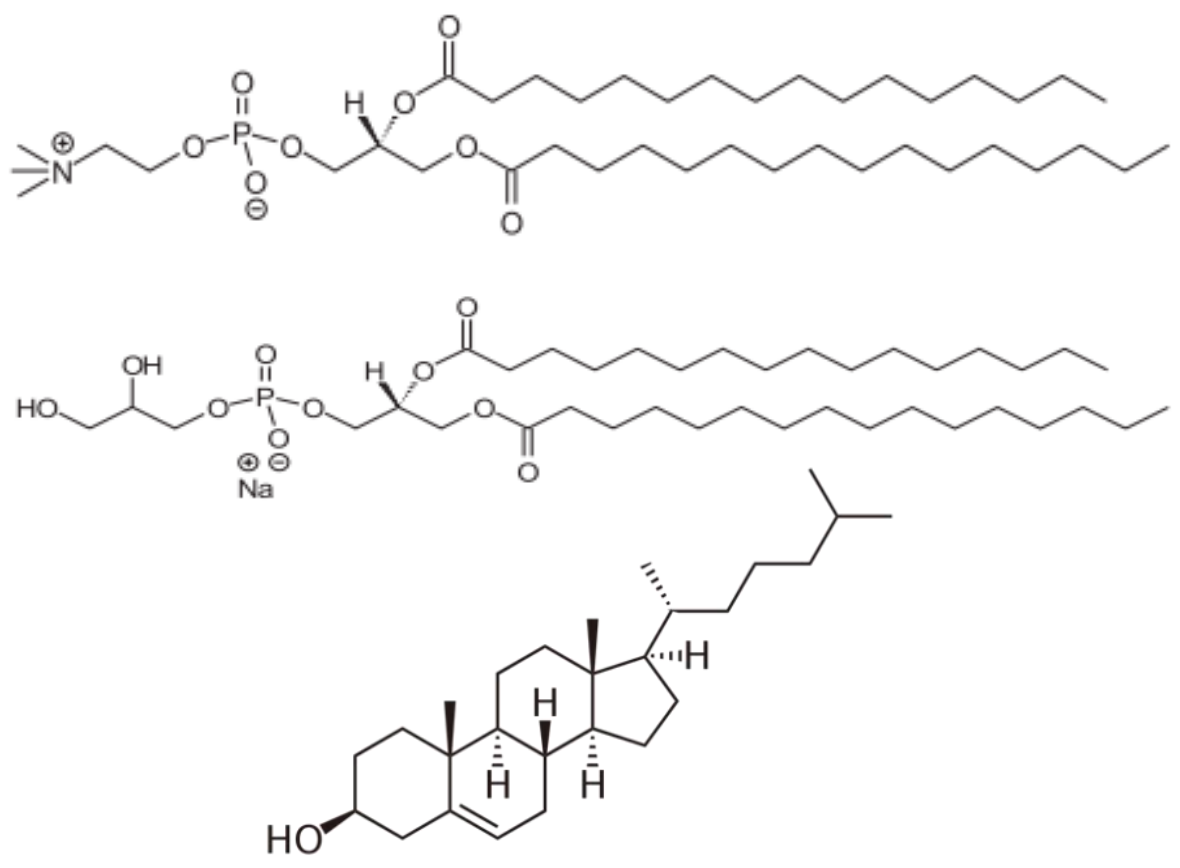

Figura 2: Representação das estruturas do DPPC (acima), DPPG (meio) e Colesterol (abaixo).

As proteínas surfactantes SP-A e SP-D, hidrofílicas, pertencem à família das proteínas colectina, um grupo proteico que faz parte do sistema imunológico inato, se incorporando facilmente nos alvéolos graças a afinidade com o DPPC (GOERKE, 1998). Essas proteínas estão ligadas diretamente à defesa do pulmão (OLMEDA; GARCÍA-ÁLVAREZ; PÉREZ-GIL, 2012). Já as proteínas SPB e SP-C são proteínas hidrofóbicas ligadas fortemente aos fosfolipídios, contribuindo diretamente na estabilidade mecânica dos filmes e aumentando a adsorção de moléculas ativas da interface ar-água. A deficiência dessas proteínas, especialmente as duas últimas, em surfactantes levam a patologias respiratórias. A falta de SP-B pode levar à letalidade, demonstrando a relação direta entre as propriedades biofísicas e funcionais do surfactante pulmonar com o desempenho do pulmão. As proteínas SP-B e SP-C reduzem a temperatura crítica de transição de fase do DPPC em bicamadas de 41 para $37^{\circ} \mathrm{C}$ aproximadamente. Isso sugere que aumentando a adsorção proteica, a fluidez da monocamada tende a aumentar, assim como a velocidade de dispersão na interface ar-água (HILLS, 1999). 
Segundo a Equação de Young-Laplace (Equação 1) para estruturas esféricas, a diferença entre a pressão interna do alvéolo pulmonar e a pressão externa $(\Delta \mathrm{P})$ se relaciona de forma diretamente proporcional com sua tensão superficial $(\gamma)$ e inversamente proporcional ao seu raio $R$ (de aproximadamente $1 \mathrm{~mm}$ ). Desta forma, um trabalho significativo é necessário para a expansão deste alvéolo no processo de inalação-exalação. A Equação também indica que alvéolos de tamanhos diferentes possuem pressões internas diferentes (BAOUKINA; TIELEMAN, 2016).

$$
\Delta \mathrm{P}=\frac{2 \gamma}{\mathrm{R}}
$$

Quando os fosfolipídios do surfactante pulmonar são adsorvidos no alvéolo pulmonar, a tensão superficial diminui e pode ser descrita através da Equação 2, sendo yo a tensão superficial na interface ar-água pura, a área molecular por lipídio (APL) e a pressão de superfície resultante das interações das moléculas ( $\Pi(A L)$. O aumento ou diminuição da tensão superficial depende da densidade molecular na superfície, que é inversamente proporcional à área por lipídio, ou seja, a tensão superficial irá diminuir quando a densidade for maior na superfície, diminuindo a área média disponível por lipídio (SELLADURAI et al., 2016). A densidade pode aumentar quando se tem adsorção de surfactante na subfase ou quando se comprime a interface (VELDHUIZEN et al., 1998). Assim, o surfactante pulmonar permite a estabilidade alveolar e possibilita que os alvéolos de diferentes tamanhos funcionem com a mesma eficácia, conforme se observa na Figura 3 (DAVIS; FLEMING; KEOUGH, 1981).

$$
\gamma(\mathrm{APL})=\gamma_{\mathrm{O}}-\pi(\mathrm{AL})
$$



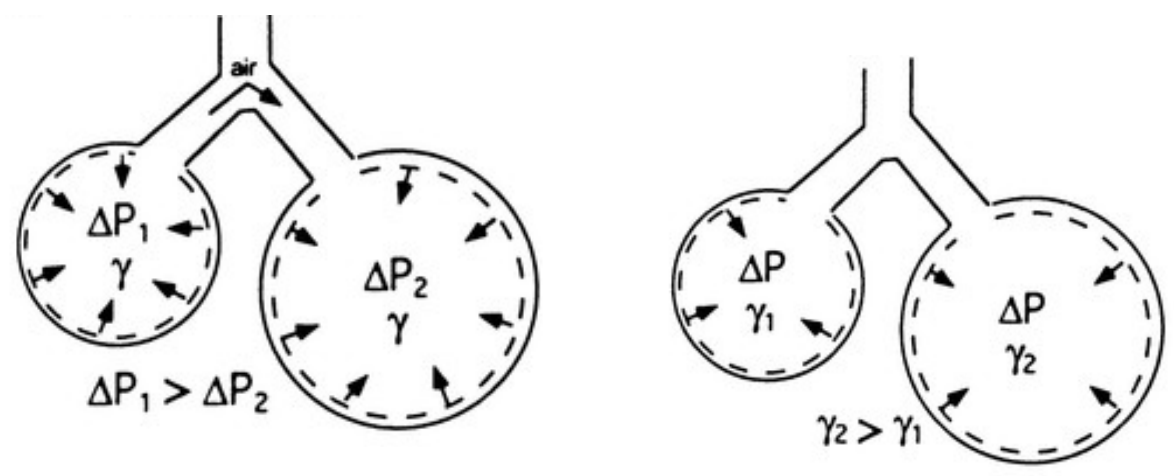

Figura 3: llustrações dos alvéolos pulmonares de diferentes tamanhos e pressões: Instável (esquerda) e Estável (direita) [(HILLS, 1999) - Modificado].

A densidade superficial (o inverso da área por lipídio) pode ser aumentada através da compressão da interface ou pela adsorção do surfactante na subfase. Essa densidade gera uma dependência inversamente proporcional à tensão superficial. O surfactante pulmonar adsorvido na interface gera uma tensão superficial de equilíbrio na faixa de 20 a $25 \mathrm{mN} \mathrm{m}^{-1}$ e, na exalação, com a compressão alveolar, a densidade superficial aumenta e a tensão superficial pode chegar ao valor de zero. Neste momento também ocorre a exclusão de alguns lipídios, fosfolipídios insaturados e proteínas da monocamada, ficando ela enriquecida com DPPC (que é o fosfolipídio mais importante para a redução da tensão superficial do alvéolo). Com a posterior inalação, a tensão superficial torna a aumentar até a faixa de equilíbrio. Assim, a monocamada do surfactante pulmonar encontra-se num estado metaestável entre a tensão de equilíbrio e colapso e mostra-se que a interface ar-água, na qual atua a tensão superficial, é instável e varia de acordo com o ciclo respiratório (PANDA et al., 2003) (ZUO et al., 2008).

Estudos científicos têm demonstrado que há uma coexistência de fases tanto em monocamadas de surfactante pulmonar quanto em bicamadas lipídicas devido aos ciclos respiratórios e essas diferentes fases têm relação com a estabilidade dos filmes. A mistura de fosfolipídios com diferentes temperaturas de transição (como mencionado para DPPC e POPG) permite que o surfactante pulmonar seja uma mistura fluida, característica fundamental para ser adsorvido de forma rápida na interface. Suas fases conhecidas são chamadas de líquido condensado (LC), líquida expandida (LE) e líquida organizada (LO), ilustradas 
na Figura 4, possuindo características diferentes entre si quanto à sua disposição, gerando propriedades diferentes para o filme. Desta forma, as moléculas do surfactante se organizam através destas transições de fases até chegar o colapso, em pressões de superfície de aproximadamente $65 \mathrm{mN} \mathrm{m}^{-1}$ (CASALS; CANADAS, 2012; MONSEN; BAGATOLLI, 2004; PÉREZ-GIL, 2008; WORTHMAN et al., 1997).

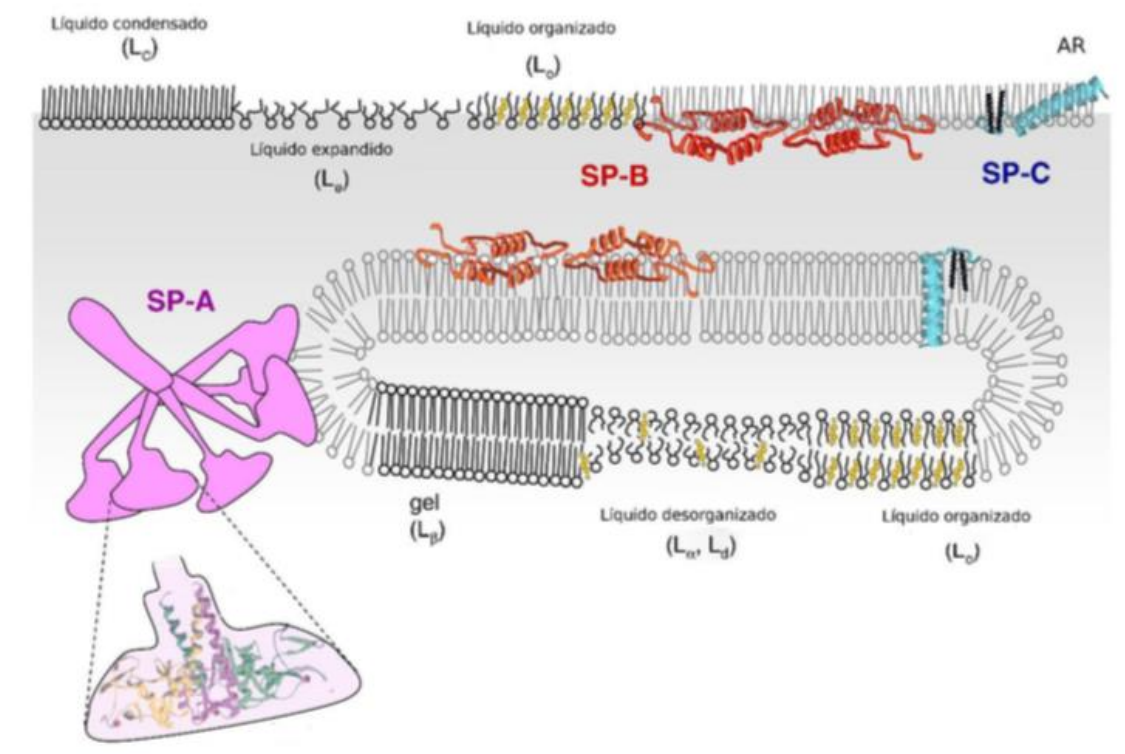

Figura 4: Fases da monocamada de surfactante pulmonar (NAG et al., 1991)

Em temperatura fisiológica, próxima dos 37 graus Celsius, sob baixos níveis de compressão e empacotamento, as cadeias hidrocarbônicas dos fosfolipídios apresentam grande liberdade de movimento, caracterizando a fase líquido expandido (LE). Sob condições contrárias, ou seja, altos níveis de compressão e empacotamento, é caracterizada a fase líquido condensado (LC). Quando há a influência do colesterol na estrutura do surfactante, com redução do grau de empacotamento e dando maior mobilidade aos fosfolipídios em relação à fase LC, a região é denominada líquido ordenado (LO), sendo considerada uma região intermediária. $\mathrm{Na}$ fase $\mathrm{LC}$, as estruturas dos fosfolipídios estão dispostas como a de um sólido semicristalino; já a fase LE é uma fase fluida desordenada, apresentando um filme flexível e resistente (SEEHASE et al., 2012). Alguns lipídios apresentam também a fase sólida (S) antes do colapso da monocamada. 
A variação da pressão de superfície (П) influencia diretamente no comportamento das moléculas do filme como pode ser representado na Figura 5. Quando as moléculas do filme não interagem entre si, o filme de superfície é semelhante a um gás e, com o aumento da pressão, ocorre a transição para as fases LE, LO e LC. (DUNCAN; LARSON, 2010).

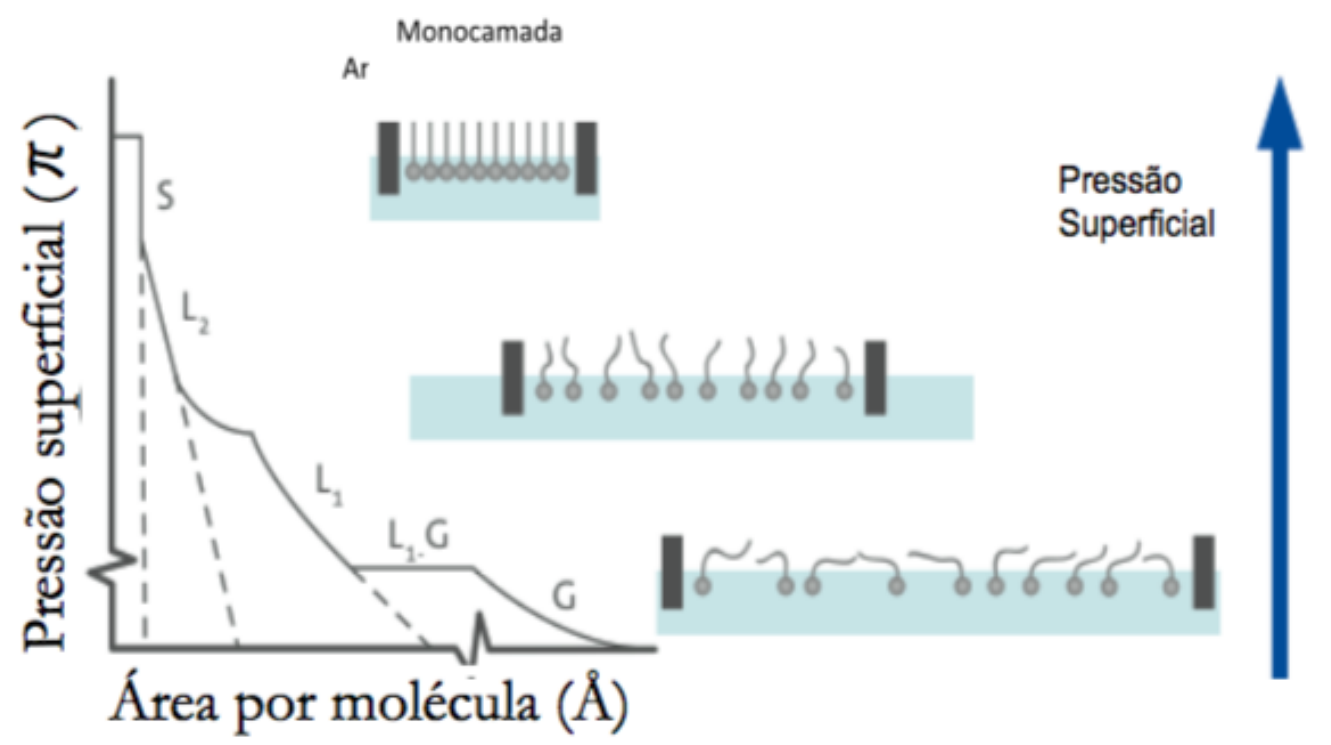

Figura 5: Comportamento das moléculas em uma monocamada (A. A. HIDALGO, A. S. PIMENTEL, M. TABAK AND O. N. OLIVEIRA, 2006)

Define-se como período de maturação do pulmão o tempo para produção de surfactante pulmonar suficiente para a independência do funcionamento do pulmão, e sua consequente redução de pressão. Este período se dá por volta das 32 semanas de gestação, mostrando que quanto mais prematura for a criança, maior será a probabilidade deste bebê não ter produzido surfactante suficiente (ou até mesmo nenhum surfactante) que pode causar o colabamento do alvéolo, tornando mais dificultosa sua capacidade de se encher de ar na inspiração, situação também conhecida como atelectasia pulmonar (RUDIGER et al., 2005). A doença da membrana hialina, ou atualmente conhecida como síndrome do desconforto respiratório do recém-nascido, é a doença caracterizada pela dificuldade que o bebê possui ao respirar por não possuir quantidade suficiente de surfactante pulmonar, necessitando de aplicações de surfactante pulmonar exógeno no pulmão do bebê (LOCCl et al., 2014). 
A busca por novos modelos lipídicos de surfactantes pulmonares visa sua aplicação para suprir a falta dos surfactantes naturais, sendo a base deles 0 DPPC. Segundo Schuer (2020), os modelos devem ser reprodutíveis, robustos e devem prever propriedades dos surfactantes pulmonares naturais (SCHUER, JULIA J; ARNDT, ALEXEJ; WOLK, CHRISTIAN, PINNAPIREDDY, SHASHANK, R; BAKOWSKY, 2020). Esses surfactantes propagam-se eficientemente e em seguida formam filmes finos e estáveis nos alvéolos que resistem ao desbaste rápido e ao umedecimento. Survanta ${ }^{\circledR}$ e Curosurf ${ }^{\circledR}$ são exemplos de surfactantes pulmonares exógenos utilizados mundialmente derivados lipídicos de extrato de pulmão bovino e suíno, respectivamente. Outros modelos comerciais são o BNS, do inglês Bovine Natural Surfactant, que é obtido através da lavagem broncopulmonar de bovinos recém abatidos, mantendo em sua composição a maioria dos componentes do surfactante endógeno, BLES e Infasurf, que, durante a fabricação, sofrem extração orgânica tendo as proteínas SP-A, SP-B e SP-C totalmente ou parcialmente removidas (ZHANG et al., 2011). Estes surfactantes são comercialmente disponíveis em soluções estéreis para aplicação intratraqueal (CHRISTMANN et al., 2009). Foi observado que esses surfactantes são rapidamente incorporados ao tecido pulmonar e sua aplicação não interfere nas vias metabólicas do surfactante endógeno, não havendo inibição em sua produção. Após poucos minutos da primeira aplicação já é notado o aumento da oxigenação do sangue (POLIN; CARLO, 2008).

Apesar do alto desempenho dos surfactantes exógenos demonstrados durante os últimos anos, a produção ainda não satisfaz a demanda mundial de sua utilização porque a matéria prima de qualidade para a produção de medicamentos a serem utilizados em humanos não é suficientemente disponível. Somando-se aos altos custos de produção, a busca por alternativas mais baratas é encontrada em produtos artificiais ou sintéticos mais simples (MINGARRO et al., 2008). Survanta, por possuir menor quantidade de lipídios em sua composição, é suplementado com DPPC, além de possuir colesterol. Já o Curosurf, por ter maior concentração lipídica, não sofre adição de DPPC e seus lipídios neutros são removidos por cromatografia (BLANCO; PÉREZ-GIL, 2007). A Tabela 1 mostra a composição destes surfactantes. 


\begin{tabular}{|c|c|c|}
\hline Composição (\%) & Curosurf & Survanta \\
\hline Fosfolipídios & 99 & 84 \\
\hline FC & $78(67,5)$ & $62-87$ \\
\hline DPPC (\%FC) & $35-56$ & 70 \\
\hline Colesterol & NR & 0,2 \\
\hline Proteínas (SP-B + SP-C) & 1 & $0,5-1$ \\
\hline
\end{tabular}

Tabela 1: Composição dos surfactantes pulmonares em quantidades relativas em percentual. [(CHRISTMANN et al., 2009) - Adaptado]. *NR = Não representativo

A utilização de surfactantes pulmonares exógenos em bebês recémnascidos torna-se uma opção viável que pode reduzir bruscamente o índice de mortalidade nestes casos, através de administração intratraqueal ou até mesmo em aerossol, a fim de manter a estabilidade pulmonar e, consequentemente, a função pulmonar. Porém, os estudos científicos sobre suas aplicações ainda não foram encerrados, havendo constantes pesquisas sobre sua atuação quando aplicado no bebê após dias de seu nascimento. Além disso, já estão surgindo estudos que demonstram a sua eficácia para tratamento de outras doenças. Consequentemente, isto implica na importância do campo das pesquisas de suas propriedades reológicas para realizar o controle de qualidade desse medicamento ou o desenvolvimento de novos modelos de surfactantes (SEEHASE et al., 2012).

Os surfactantes pulmonares sintéticos possuem uma composição mais uniforme e não apresentam risco potencial para transmissão de doenças. Esperam-se isotermas semelhantes para os modelos de surfactantes pulmonares comerciais, apesar de serem esperadas características reológicas distintas devido à diferença na composição. Desta forma, precisam se espalhar eficientemente, e na região alveolar, precisam também formar um filme fino e estável. Assim, as propriedades termodinâmicas e de transporte dos modelos de surfactantes são de fundamental importância (SCHUER, JULIA J; ARNDT, ALEXEJ; WOLK, CHRISTIAN, PINNAPIREDDY, SHASHANK, R; BAKOWSKY, 2020). A velocidade de espalhamento destes materiais nos alvéolos pulmonares depende diretamente de suas propriedades dinâmicas de adsorção, sendo o tempo de estabilização do Survanta próximo de 1 hora, e do Curosurf, cerca de 
1 minuto (BYKOV, A. G.; MILYAEVA, O. YU.; ISAKOV, 2020). Os modelos mais simples de surfactante pulmonar, tais como DPPC:SP-C, possuem uma alta viscoelasticidade, e à medida que é adicionado colesterol (DPPC:SP-C + colesterol) ao surfactante pulmonar, a viscosidade de cisalhamento interfacial reduz bruscamente (ALONSO; WARING; ZASADZINSKI, 2005; CHOI et al., 2014).

As propriedades reológicas dos surfactantes pulmonares podem variar de acordo com a frequência respiratória a qual os alvéolos pulmonares estão submetidos. Este ritmo respiratório é determinado pelo número de ciclos respiratórios que o indivíduo realiza em um determinado intervalo de tempo. Normalmente, é expressa em respirações por minuto e o movimento rítmico entre a inspiração e expiração é regulado pelo sistema nervoso central. O ciclo respiratório possui velocidades diferentes para cada etapa da vida humana (conforme tabela 2) e aumenta com a prática de exercícios físicos, tornando o coração mais acelerado, para bombear mais sangue para o corpo e efetuar a troca gasosa mais rapidamente. $\mathrm{O}$ ciclo respiratório também pode ser dividido em quatro fases, que são: fase inspiratória, mudança da fase inspiratória para a fase expiratória, fase expiratória e mudança de fase expiratória para a inspiratória. Em cada etapa há uma mudança na pressão do pulmão conforme mostrado na Figura 6 (FORNAZIER et al., 2011).

\begin{tabular}{|c|c|}
\hline Idade & Frequência Respiratória Normal \\
\hline Recém-nascidos & 44 \\
\hline Crianças de até 7 anos & $18-30$ \\
\hline Pré-adolescentes & $20-30$ \\
\hline Adolescentes & $18-26$ \\
\hline Adultos & $12-20$ \\
\hline Idosos acima de 65 anos & $12-28$ \\
\hline Atletas em atividades físicas & $60-70$ \\
\hline
\end{tabular}

Tabela 2: Indicação da frequência respiratória normal (em respirações por minuto) de acordo com a faixa etária do ser humano (GAZITÚA, R. 2014) (LINDH, W. et al. 2014) (RODRíGUEZMOLINERO, A. et al. 2013) (MCARDLE, WILLIAM D. et al. 2006). 


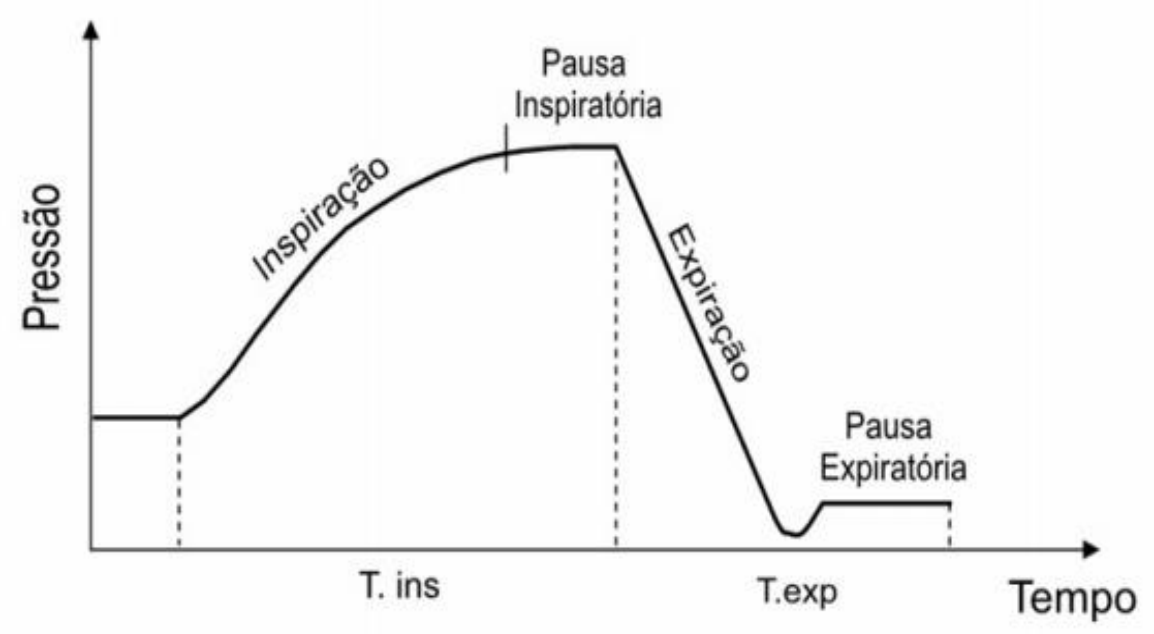

Figura 6: Alteração da pressão no ciclo respiratório (FORNAZIER et al., 2011).

As frequências respiratórias se relacionam às frequências de cisalhamento aplicadas nos experimentos de reologia interfacial utilizando o ISR. Estudos na área com baixas frequências podem se relacionar ao ritmo respiratório de crianças até adultos; frequências intermediárias, à respiração de recém-nascidos e, altas frequências, a atletas em exercício. Assim, torna-se fundamental o estudo sob altas frequências de cisalhamento para entendermos melhor o funcionamento do surfactante pulmonar nos alvéolos pulmonares de atletas com a prática de exercícios físicos. 


\subsection{Reologia e Propriedades Reológicas}

Reologia é o ramo da ciência responsável pelo estudo do escoamento e das deformações da matéria, tendo como foco principal a viscosidade, plasticidade e elasticidade, descrevendo a deformação sob influência de tensões, sendo importante para o desenvolvimento e controle de qualidade de suspensões comerciais, por exemplo. Particularmente, a reologia interfacial se preocupa com deformações da interface, sendo de dois tipos, de acordo com o tipo de deformação: a reologia de cisalhamento interfacial, e a reológica dilatacional interfacial. Enquanto a segunda é medida através uma tensão que altere a área interfacial, a reologia de cisalhamento interfacial não provoca mudança de área interfacial, mas um corpo de prova deve se deslocar pela superfície. Neste sentido, dois conceitos tornam-se fundamentais: tensão de cisalhamento $(\sigma)$ e taxa de cisalhamento $(\dot{\gamma})$ (SCHRAMM, 2006).

Muitos tipos de forças atuam sobre um fluido em movimento. Essas forças têm origem devido à gravidade, às interações entre as moléculas, aos gradientes de pressão e ao próprio movimento dinâmico. Quando uma força atua em determinada área de fluido, gera-se uma tensão. Ao serem aplicadas na direção do movimento do fluido, mas em sentido oposto, gera-se uma tensão de cisalhamento $(\sigma)$, que dificulta a fluidez devido a transferência de momento linear eficiente entre as camadas adjacentes. A tensão de cisalhamento é a componente da tensão aplicada a um material que faz com que suas camadas paralelas transfiram momento linear entre planos de cisalhamento em contato. Desta forma, o deslocamento relativo no plano de duas camadas paralelas desse material dividido pela distância entre essas camadas (y), chama-se taxa (ou gradiente) de cisalhamento $(\dot{\gamma})$, que pode ser calculada pela variação da velocidade ( $v$ ) entre camadas paralelas a qual sofrem a tensão de cisalhamento, calculada pela Equação 3 (SCHRAMM, 2006).

$$
\dot{\gamma}=\frac{d v}{d y}
$$


Uma relação entre a tensão de cisalhamento e taxa de cisalhamento foi determinada por Newton, como descrita na Equação 4. O coeficiente de proporcionalidade entre $\sigma$ e $\dot{\gamma}$ é a viscosidade aparente do fluido, ou viscosidade. Essa relação classifica os fluidos como newtonianos (cuja viscosidade não se altera sob diferentes taxas de cisalhamento, como água e leite) e não newtonianos (que apresentam comportamento não ideal e a viscosidade altera sob diferentes taxas de cisalhamento, como polímeros). No caso de fluidos não newtonianos, o fluido é chamado de dilatante quando a viscosidade aumenta com o aumento da taxa de cisalhamento. Caso contrário, o fluido é classificado como pseudoplástico. A relação entre as viscosidades e taxas de cisalhamento de fluidos newtonianos e não newtonianos é exibida na Figura 7 (SCHRAMM, 2006).

$$
\eta=\frac{\sigma}{\dot{\gamma}}
$$

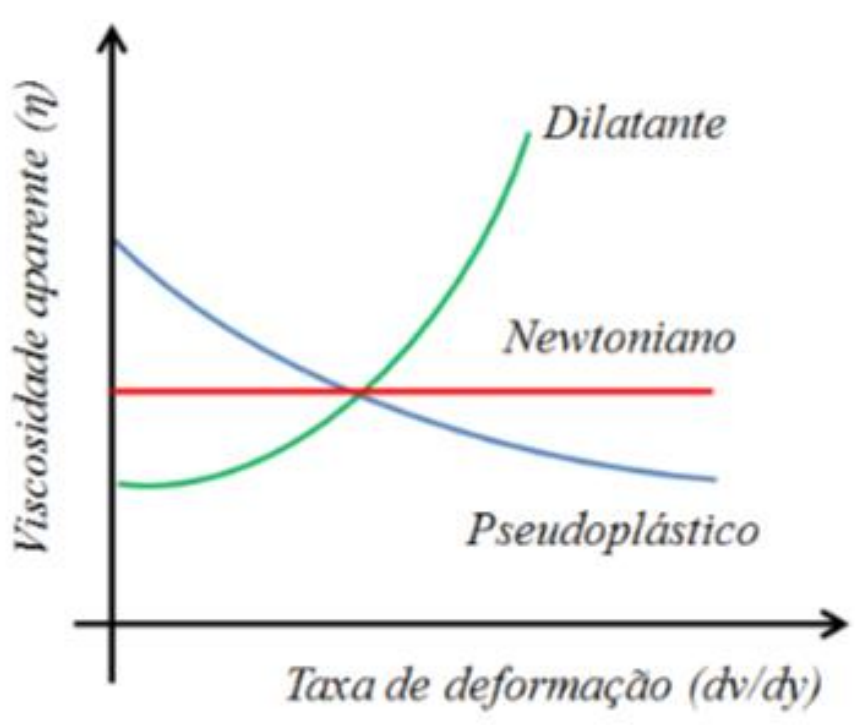

Figura 7: Relação entre $\sigma$ e $\dot{\gamma}$.

A viscosidade pode ser entendida como a resistência de um fluido quando submetido à deformação sob aplicação de uma tensão ou agitação. Essa propriedade está relacionada à coesão, às interações moleculares, e à força necessária para retirá-las do repouso, podendo ser observada em fluido em movimento, indicando sua capacidade em escoar. O inverso da viscosidade é conhecido como fluidez. Essa propriedade depende condições externas, como 


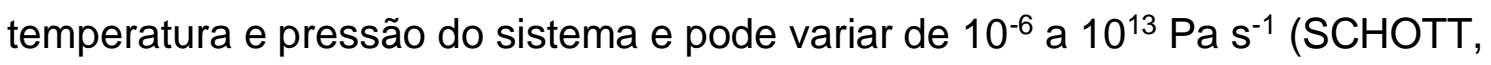
1992).

Os tipos mais importantes de viscosidade são a viscosidade complexa $\left(\eta^{*}\right)$, que é a função da viscosidade que depende da frequência da oscilação harmônica forçada da tensão de cisalhamento conforme Equação 5, a viscosidade fora de fase ( $\eta$ '), que é a componente complexa da viscosidade, determina pela razão entre o módulo de armazenamento e a frequência angular, conforme Equação 6, viscosidade cinemática (v), que é a razão entre a viscosidade do fluido por sua densidade, conforme Equação 7, e viscosidade de cisalhamento zero $\left(\eta_{0}\right)$, que é o limite da viscosidade sob baixa taxa de cisalhamento, conforme descreve a Equação 8 (SHU-PING LI; GE ZHAO; HONG-YUAN, 2006).

$$
\begin{aligned}
& \eta *=\frac{\sqrt{G^{2}+G \prime^{2}}}{\mathrm{f}} \\
& \eta^{\prime}=\frac{G^{\prime}}{\omega} \\
& v=\frac{\eta}{\rho} \\
& \eta о=\lim _{\gamma \rightarrow 0} \eta
\end{aligned}
$$

No estudo de suspensões, como os surfactantes pulmonares, quando as condições não lineares de cisalhamento são aplicadas, espera-se uma resposta não newtoniana no comportamento do fluido. Sob cisalhamento constante, a viscosidade dinâmica pode ser relacionada à viscosidade complexa do material e pode ser obtida através de análises do comportamento das taxas de deformação do fluido analisado, apresentando respostas semelhantes. A hipótese de Cox-Merz é uma regra empírica que afirma que a dependência da viscosidade de cisalhamento constante sobre a taxa de cisalhamento pode ser estimada a partir da viscosidade dinâmica em função da frequência, pois as duas curvas são aproximadamente idênticas, conforme Equação 9 (LI; ZHAO; CHEN, 2005).

$$
|\eta(\omega)|=\eta(\dot{\gamma})
$$


Se uma monocamada na superfície de um líquido de viscosidade $\eta_{0}$ for submetida a uma tensão de cisalhamento $\sigma$ na direção vertical $z$ e sendo $v$ a velocidade na direção $\mathrm{x}$ variando ao longo de y, a taxa de cisalhamento $\dot{\gamma}$ e a tensão de cisalhamento podem ser calculadas no regime linear através das Equações 10 e 11, respectivamente. Próximo a superfície, a viscosidade local varia e a tensão de cisalhamento pode ser descrita utilizando uma viscosidade $\eta(z)$ igual a $\eta_{0}$ (longe da superfície) que aumenta gradativamente quanto mais próximo da superfície devido à presença da monocamada, conforme Equação 12. A Figura 8 mostra um esquema da variação de $\eta$ em relação ao eixo vertical z próximo da superfície. A área do gráfico é o valor da viscosidade superficial $\eta_{\mathrm{s}}$. (LANGENVIN, 2014).

$$
\begin{gathered}
\dot{\gamma}=\frac{\partial \mathrm{v}}{\partial \mathrm{y}} \\
\sigma=\eta \mathrm{o} \frac{\partial \mathrm{v}}{\partial \mathrm{y}} \\
\eta S=\int_{-\infty}^{0}[\eta(\mathrm{z})-\eta \mathrm{o}] \mathrm{dz}+\int_{0}^{+\infty} \eta(\mathrm{z}) \mathrm{dz}
\end{gathered}
$$

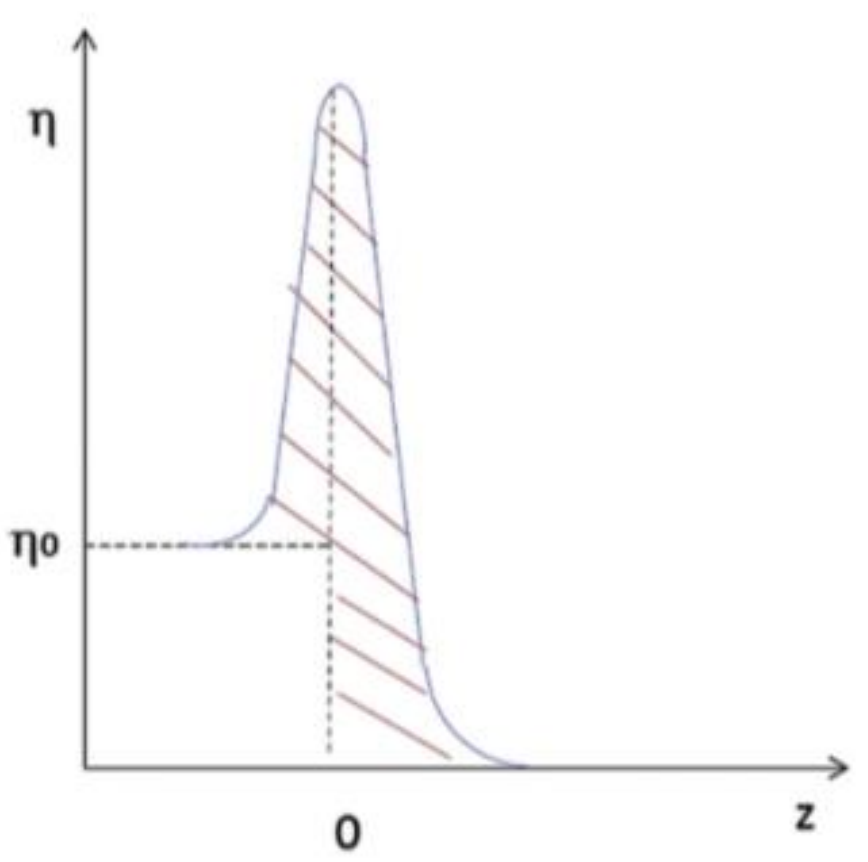

Figura 8: Variação de $\eta$ em função de z (LANGENVIN, 2014). 
Deformação é o conceito utilizado quando a posição de moléculas de um fluido é modificada através da ação de uma tensão, de modo que a continuidade do corpo não seja destruída, resultando na mudança de forma e/ou volume. As deformações em fluidos podem ser elásticas (reversíveis) ou plásticas (irreversíveis). A deformação elástica é apresentada por sistemas que retornam a suas formas e/ou volumes originais após seu término. Já na deformação plástica, também conhecida como escoamento, o material não retorna a sua forma e volume originais, dissipando energia sob forma de calor quando submetido à deformação. Existem fluidos que, simultaneamente, se deformam e sofrem deformações elásticas e viscosas, ou seja, apresentam característica viscoelástica e, como tal, exibem deformação dependente do tempo. A elasticidade é consequência do alongamento da interação química ao longo dos planos ordenados.

Do ponto de vista reológico, as propriedades mecânicas dos materiais são descritas por contribuições inerciais, elásticas ou viscosas. Neste sentido, a deformação inercial não envolve aceleração, a deformação elástica normalmente é expressa em função da tensão de cisalhamento aplicada e a deformação viscosa através da taxa de cisalhamento (LANGENVIN, 2014).

Portanto, a característica elástica permite que o material seja tensionado quando é esticado e retorna ao seu estado original após cessar-se a deformação. Já a característica viscosa é responsável pela resistência do material ao fluxo de cisalhamento, apresentando variação linear do esforço com o tempo quando a tensão é aplicada (MEYERS, MARE; CHAWLA, 2009).

Com relação à reologia interfacial, os materiais que apresentam comportamento viscoelástico, quando submetidos à tensão de cisalhamento, apresentam um módulo interfacial de cisalhamento $\left(G^{*}\right)$ que descreve seus comportamentos interfaciais, sendo uma relação entre a tensão de cisalhamento aplicada e a resposta da deformação causada em condições oscilantes. Este módulo pode ser representado em sua forma complexa, sendo formado por uma parte real e outra imaginária, conforme apresentado na Equação 13. A parte real chama-se módulo de armazenamento elástico ( $G$ '), responsável pela rigidez do material, armazenando energia elástica e, posteriormente, restituindo-a. A componente complexa é o módulo de perda viscosa (G'), sendo responsável pela energia dissipada pelos movimentos moleculares, determinando 0 
comportamento viscoso do material (RAO, 1992) (MIRKA KORHONEN; LEENA HELLEN; JOUNI HIRVONEN, 2001).

$$
\{\mathrm{G}\}=\mathrm{G}^{\prime}+\mathrm{iG}^{\prime \prime}
$$

onde $\mathrm{i}^{2}=-1$

A propriedade viscoelástica de fluidos pode ser entendida como um rearranjo molecular. Uma tensão de cisalhamento aplicada causa a reorganização de moléculas, que é chamada de fluidez interfacial. Assim, algumas conformações são energeticamente favorecidas em relação a outras. Como o movimento térmico é um fator que contribui para a deformação de materiais, as propriedades viscoelásticas variam em função da temperatura. Geralmente, uma tensão menor é necessária para deformar um material sob maiores temperaturas (KRAGEL et al., 1996).

A Lei de Hooke relaciona proporcionalmente os parâmetros tensão e taxa de cisalhamento conforme a Equação 14, sendo o módulo dinâmico de superfície a constante de proporcionalidade. Um corpo que obedece a esta lei não pode ser viscoelástico e nem escoa, ou seja, não sofre aumento contínuo da deformação sob ação de uma tensão. As análises reológicas necessitam da determinação da região de Regime Viscoelástico Linear (RVL), onde G é independente da tensão de cisalhamento ou deformação em uma determinada temperatura. Apesar desta lei impor uma mudança linear da deformação em relação à tensão que se aplica sobre o filme, não é sob qualquer faixa de frequência ou pressão que esta proporcionalidade acontece. Caso as medições sejam realizadas fora desta região, os resultados obtidos podem não ter valor científico. Em curvas de tensão $x$ deformação, uma característica em comum encontrada é a histerese, cuja área abaixo da curva representa a energia dissipada ao término da carga.

$$
\sigma=\mathrm{G} \times \dot{\gamma}
$$


Tanto a tensão $(\varepsilon)$ quanto a tensão de cisalhamento $(\sigma)$ possuem comportamentos oscilantes senoidais. Estas propriedades podem ser determinadas pelas Equações 15 e 16, respectivamente. Nos experimentos reológicos, a diferença do ângulo de fase ( $\delta$ ) entre a deformação e a tensão de cisalhamento é um importante objeto de estudo, pois é relacionado diretamente ao comportamento elástico, viscoso ou viscoelástico de monocamadas. Idealmente, materiais puramente elásticos não possuem defasagem entre $\sigma$ e a deformação $\left(\delta=0^{\circ}\right)$ pois toda energia é armazenada e restituída no material. Já materiais viscosos possuem $\delta>75^{\circ}(\tan =3,7)$ e dissipam toda a energia quando $\delta=90^{\circ}$. Os módulos de armazenamento e perda podem ser relacionados à amplitude da tensão $\varepsilon_{0}$ e à amplitude da tensão de cisalhamento $\sigma_{0}$ conforme as Equações 17 e 18. A Tabela 3 correlaciona $\delta$ com as características elástica, viscosa e viscoelástica.

$$
\begin{aligned}
& \varepsilon=\varepsilon 0 \operatorname{sen}(\omega t) \\
& \sigma=\sigma o \operatorname{sen}(\omega t+\delta)
\end{aligned}
$$

Onde, $\omega=2 \pi f$

$$
\begin{aligned}
& G^{\prime}=\frac{\sigma 0}{\varepsilon 0} \cos \delta \\
& G^{\prime \prime}=\frac{\sigma o}{\varepsilon 0} \operatorname{sen} \delta
\end{aligned}
$$

\begin{tabular}{|c|c|c|}
\hline Faixas de $\delta$ & Tan $\delta$ & Comportamento do filme \\
\hline$\delta<10^{\circ}$ & Menor que 0,17 & Elástico \\
\hline $10^{\circ} \geq \delta \leq 75^{\circ}$ & $0,17<$ Tan $<3,7$ & Viscoelástico \\
\hline$\delta>75^{\circ}$ & Maior que 3,7 & Viscoso \\
\hline
\end{tabular}

Tabela 3: Relação entre tan $\delta$ e os comportamentos do filme.

Outro parâmetro importante que descreve a resposta de um filme sob tensão de cisalhamento é a tan $\delta$, que fornece uma medida de dissipação no material. O parâmetro pode ser visualizado no espaço vetorial como a tangente do ângulo de fase $(\delta)$ entre os módulos de perda e armazenamento, e calculado 
através da razão destes parâmetros, conforme Equação 19. Um material que possui tan $\delta$ maior que 1, apresentará maior amortecimento do que outro material com tan $\delta$ menor que 1 , visto que sua capacidade elástica será menor que a viscosa. A frequência de estudo também se torna muito importante para as análises reológicas (BUHAENKO; GOODWIN; RICHARDSON, 1988).

$$
\tan \delta=\frac{G^{\prime \prime}}{G^{\prime}}
$$

Hermans \& Vermant (2014) analisaram a dependência da reologia de cisalhamento interfacial do DPPC em função da temperatura e pressão. Segundo os autores, os resultados encontrados na literatura são incipientes e inconsistentes porque o experimento pode não apresentar condições relevantes para o estudo ou a técnica não apresenta sensibilidade adequada. $O$ comportamento viscoelástico do DPPC foi caracterizado, sendo majoritariamente viscoso sob baixas pressões e a sensibilidade da técnica foi mantida através da mudança da geometria do sensor.

Espera-se alta viscosidade superficial para o DPPC em condições de temperatura ambiente e pressões moderadas em torno dos $30 \mathrm{mN} / \mathrm{m}$, sugerindo que tal característica é importante para manter o surfactante pulmonar nos alvéolos, reduzindo possível fluxo de Marangoni. No entanto, um valor baixo de viscosidade superficial foi detectado, sendo atribuída a sua capacidade de rápida disseminação do surfactante pulmonar, não apresentando variações significativas com a frequência. Assim, os autores sugerem que estudos são necessários para determinar se a hipótese de que a alta viscosidade é que faz manter o surfactante nos alvéolos é verdadeira (Hermans \& Vermant, 2014).

Muitos estudos de reologia interfacial do DPPC são realizados sob janela limitada de pressões e temperaturas, em condições não relevantes para o estado fisiológico do corpo humano. Tentativas fracassam quando tendem a aumentar a temperatura do experimento, obtendo dados abaixo do limite real de sensibilidade dos dispositivos utilizados (Kim et al, 2011) (Nishimura et al, 2008) (Leiske et al, 2011). 
Segundo Hermans e colaboradores (2015), compreender os diferentes modos de estabilização dos filmes dos modelos de surfactante pulmonar auxiliam no projeto de engenharia de substitutos sintéticos no desenvolvimento de novos modelos. O surfactante se espalha pelo pulmão em um tempo curto, auxiliado pela ventilação mecânica e outros fatores, graças às propriedades físicas interfaciais que permitem uma rápida disseminação. Diversos fatores podem contribuir para a eficácia clínica em geral, porém, a alta viscoelasticidade do Survanta leva a uma propagação mais lenta, tornando o Curosurf mais eficaz, ao menos sob prisma de espalhamento e estabilização (HERMANS et al, 2015).

Ivanova e colaboradores estudaram as propriedades dilatacionais de Survanta e Curosurf na interface ar/água e analisaram alta eficácia de espalhamento deste último. Segundo os autores, uma das características favoráveis de surfactantes pulmonares seria a alta elasticidade, que contribui para a manutenção da estabilidade estrutural dos alvéolos durante suas deformações que acompanham a respiração (IVANOVA et al, 2014)

A reologia interfacial dilatacional também é uma importante área da ciência para o estudo de propriedades viscoelásticas de surfactantes pulmonares, cuja principal diferença da reologia interfacial de cisalhamento é a compressão e expansão do fluido analisado (variação de volume ou de área). A Equação 20 define o módulo interfacial dilatacional (E), que é um parâmetro de resistência do fluido em criar um gradiente de tensão. Esta Equação mostra que as camadas interfaciais são compressíveis, sendo $\gamma$ a tensão interfacial e A, a área. A partir dos valores de $E$, os módulos elástico ( $E$ ') e viscoso ( $E$ ") podem ser obtidos como componentes real e imaginário, respectivamente, analogamente ao G' e G", conforme Equação 21 (RAVERA, F; LOGLIO, G; KOVALCHUK, 2010). A Figura 9 mostra didaticamente a representação das deformações dilatacional e de cisalhamento.

$$
\begin{aligned}
& E=\frac{d \gamma}{d \ln A} \\
& \mathrm{E}=\mathrm{E}^{\prime}+\mathrm{i} \mathrm{E}^{\prime \prime}
\end{aligned}
$$

onde $\mathrm{i}^{2}=-1$ 


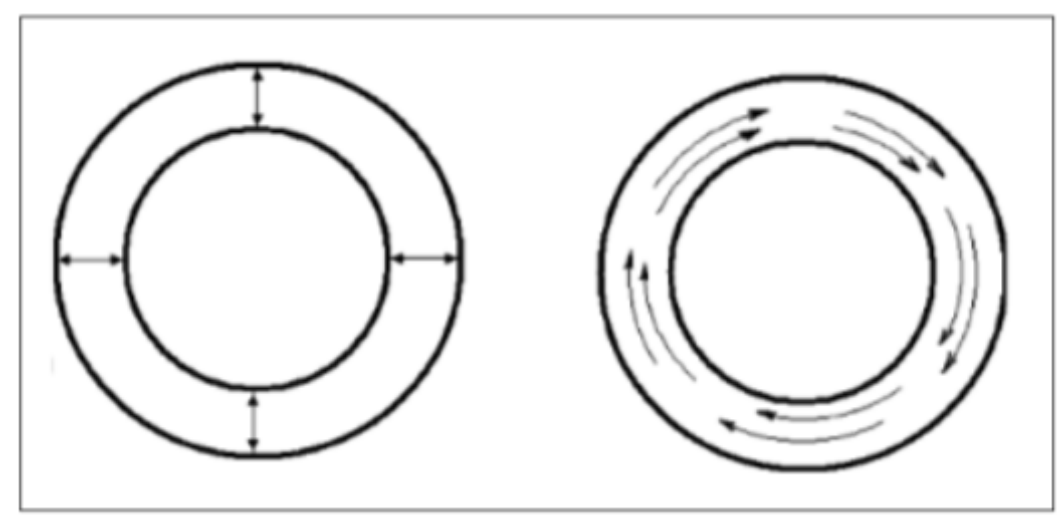

Figura 9: Representação da deformação dilatacional (esquerda) e de cisalhamento (direita). (MILLER, R; FERRI, J. K; JAVADI, 2010).

Segundo Ravera e colaboradores (2010), um equipamento largamente utilizado para atuar na medição de parâmetros interfaciais (como E' e E”) é o tensiômetro de gota. Este instrumento é capaz de medir a tensão interfacial de fluidos a partir do perfil de sua gota e é utilizado para investigar o equilíbrio e propriedades dinâmicas de interfaces simples e complexas (RAVERA, F; LOGLIO, G; KOVALCHUK, 2010). Seu princípio de funcionamento será tratado em capítulo separado

A análise do perfil da gota é feita baseando-se na Equação de Laplace (Equação 22), que relaciona o raio de curvatura da gota com a diferença de pressão entre as fases imiscíveis e a tensão interfacial. Nesta Equação, R1 e R2 representam o raio de curvatura da gota, $\gamma$ a tensão interfacial ou superficial e essa Equação norteia a parametrização para a determinação dos valores (RAVERA, F; LOGLIO, G; KOVALCHUK, 2010).

$$
\Delta P=\gamma\left(\frac{1}{R 1}+\frac{1}{R 2}\right)
$$

As propriedades mecânicas das monocamadas de fosfolipídios e seus comportamentos quando submetidas à tensão de cisalhamento e compressão desempenham um papel importante em processos biológicos, como a respiração e piscar de olhos (ALBERTO S. LUVIANO, JOSÉCAMPOS-TERAN, DOMINIQUE LANGEVIN; ESPINOSA, 2019). Essas monocamadas fosfolipídicas são modelos de membrana biológicas que aderem perfeitamente 
às interfaces fluidas. Assim, muitos estudos têm sido dedicados às medições de propriedades mecânicas e físico-químicas destas monocamadas, que podem ser caracterizadas por cisalhamento superficial e viscoelasticidade. Desta forma, quanto mais exploradas as propriedades de cisalhamento das monocamadas, mais conhecidas são suas estruturas. Estas monocamadas representam um modelo simples para uma membrana biológica, cuja estrutura primária é formada por uma bicamada fosfolipídica (ALONSO; WARING; ZASADZINSKI, 2005).

$\mathrm{Na}$ superfície, mudanças no comportamento da monocamada geradas pela redução da tensão superficial (ou aumento da pressão de superfície) causam variações da viscosidade superficial. Sob pressões de superfícies relativamente pequenas $\left(<20 \mathrm{mN} \mathrm{m}^{-1}\right)$ há basicamente fases fluidas. Ao contrário, o aumento da pressão de superfície conduz a fases condensadas e sólidas a partir de $20 \mathrm{mN} \cdot \mathrm{m}^{-1}$. Porém, em monocamadas de surfactantes pulmonares há a coexistência entre fases fluidas e condensadas, que, mesmo com pequenas mudanças em sua proporção, pode causar grandes variações na viscosidade da superfície do surfactante. A aplicação da proteína SP-C faz com que ocorra interação com os lipídios das monocamadas regulando essa viscosidade superficial (ALONSO; WARING; ZASADZINSKI, 2005). 


\subsection{Reômetro de Cisalhamento Interfacial}

O reômetro de cisalhamento interfacial (ou ISR, do inglês Interfacial Shear Rheometer) é um instrumento de caracterização avançada para o estudo da viscoelasticidade dos filmes de Langmuir, auxiliando na detecção de transições microestruturais, inclusive. Assim, além de ser aplicável em estudos de estabilidade de emulsões e espumas e no controle de propriedades interfaciais de cosméticos e produtos alimentícios, o equipamento pode ser utilizado também para estudar a reologia dos surfactantes pulmonares na interface arágua. Dentre suas aplicações, há o atual interesse no módulo dinâmico de cisalhamento, visto que tal propriedade influi diretamente em suas viscoelasticidades (ERNI; FISCHER; WINDHAB, 2003).

Os parâmetros reológicos (módulos de armazenamento e de perda, e a viscosidade interfacial) podem ser obtidos de forma dinâmica. A correlação entre esses dados com a pressão de superfície da monocamada e suas transições de fase são fundamentais para o estudo de surfactantes pulmonares. Além disso, o instrumento deve ter sensibilidade suficiente para medir módulos dinâmicos de superfície $(G)$ relativamente baixos e permitir que sejam feitas análises em tempo real de estabilização dos filmes (SÁNCHEZ-PUGA et al., 2018).

O método de funcionamento é baseado na reologia de cisalhamento interfacial, em que uma agulha (capilar de vidro oco com fio de cádmio magnetizado) posicionada na superfície do líquido dentro de uma cuba de Langmuir com barreiras hidrofóbicas móveis é utilizada para criar deformações na interface. Seus movimentos são monitorados por uma câmera posicionada de modo a captá-los opticamente e projetá-los em uma matriz de fotodiodos (como mostrado na Figura 10). Há um suporte de vidro conectado ao interior da cuba que é utilizado para manter a haste na região central da cuba e para garantir que seu eixo seja disposto paralelamente. O movimento da haste é provocado por duas bobinas de Helmholtz, que se encontram perpendicularmente em cada lado da cuba, que aplicam uma força magnética tangente à interface de modo que o gradiente líquido do campo magnético gerado entre as bobinas seja zero. Uma corrente alternada é aplicada em uma bobina, enquanto na outra há uma 
corrente constante. Desta forma, a força oscilatória aplicada à haste é conhecida e as propriedades reológicas da monocamada podem ser obtidas (VERWIJLEN et al., 2011).
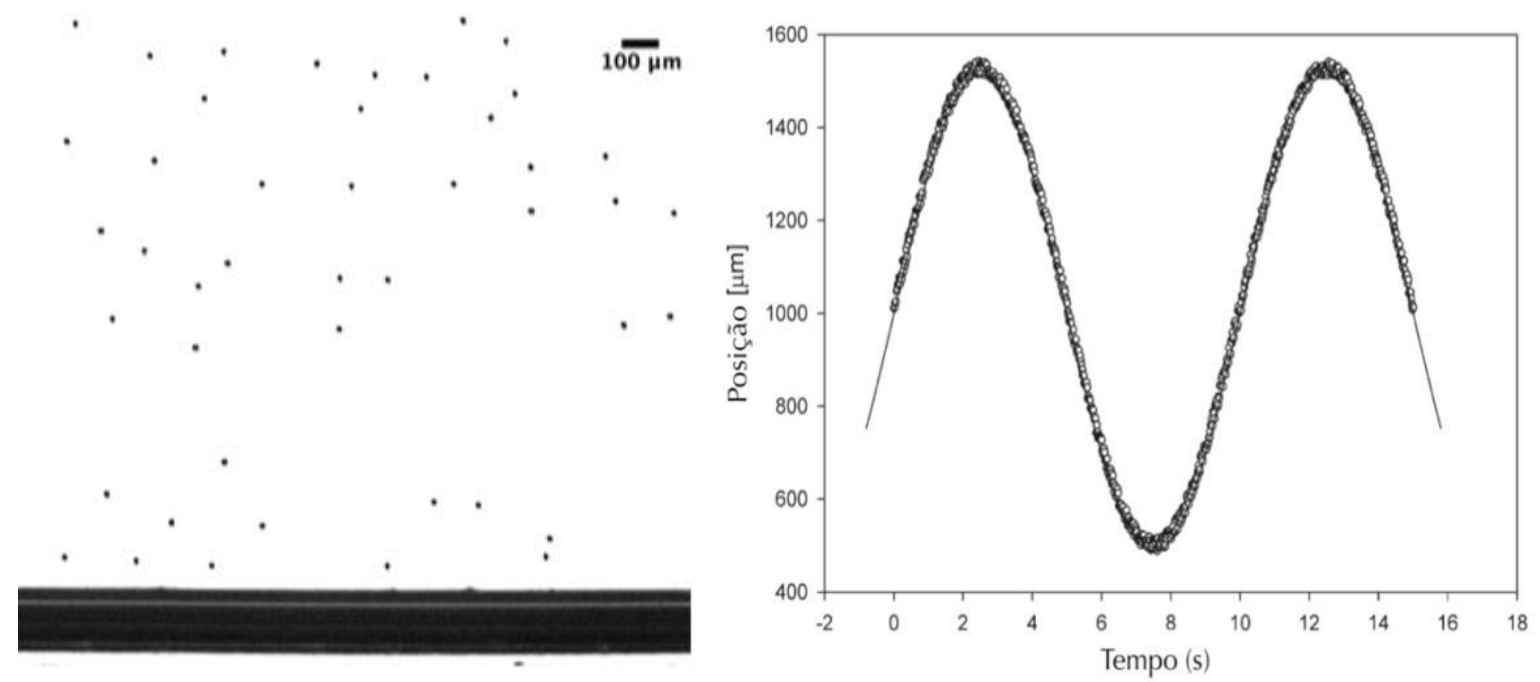

Figura 10: Imagem microscópica processada da haste na interface (esquerda) e gráfico da posição da haste em função do tempo (VERWIJLEN et al., 2011 - ADAPTADO).

O equipamento desenvolvido combina essencialmente uma cuba de Langmuir para cisalhamento superficial e módulos de determinação visual em tempo real. Algumas vantagens da técnica são: o fácil controle do empacotamento do filme por meio das barreiras móveis, que alteram a pressão de superfície, a fácil variação da frequência e sua sensibilidade, sendo o instrumento capaz de medir baixos módulos elásticos e viscosos, como nos casos dos modelos de surfactantes pulmonares. A Figura 11 mostra uma representação dos componentes do ISR. A partir do movimento da haste determinada pelo microscópio e a força aplicada, o ângulo de fase entre a tensão de cisalhamento e deformação causada podem ser determinados (ROSSINI; MOLINA; CASELI, 2017). 


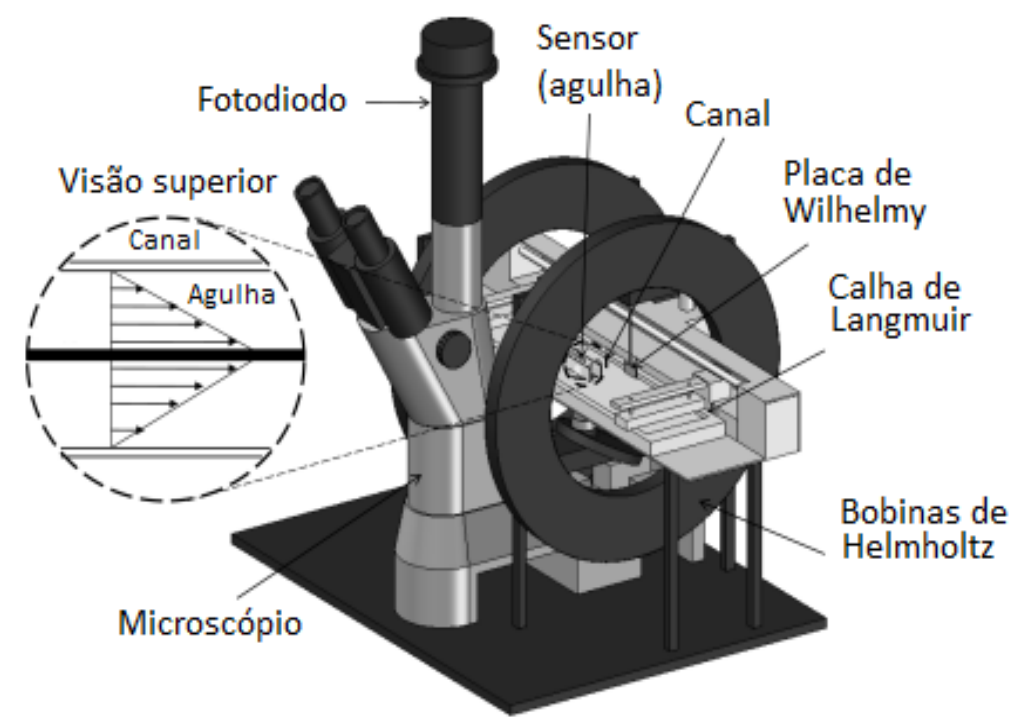

Figura 11: Representação dos componentes do ISR (VERWIJLEN et al., 2011).

A medição da tensão superficial é feita através do método da placa de Wilhelmy, utilizando geralmente de filtro de papel suspenso por um braço de uma balança e que toca perpendicularmente a interface ar-água (representado esquematicamente na Figura 12) (BROOKS et al., 1999). Em contato com o fluido, o papel de filtro mede a média da variação das forças aplicadas ao longo do tempo. A força oposta exercida pela fase líquida à placa é diretamente proporcional da tensão superficial. O princípio de funcionamento deste método o torna mais acurado e prático do que outros, como por exemplo, o método do anel de Du Nouy (BARROY; HILLS, 1979).

Apesar de ser necessário um pequeno esforço para deformar monocamadas, a capacidade de cisalhar filmes e relacionar essa informação com diferentes dados termodinâmicos requer alta sensibilidade da técnica que, inclusive, serve como base para estudos mais aprofundados, como em interações intermoleculares do filme. Alguns instrumentos já foram desenvolvidos para deformação de filmes, tais como anéis rotativos. Porém, espera-se do ISR uma maior sensibilidade na medida dos módulos de armazenamento e de perda do filme na presença de tensões de cisalhamento em uma dada pressão de superfície (GOODRICH; ALLEN; POSKANZER, 1975; STONE, 1995). 
O ISR apresenta algumas vantagens em relação a outras técnicas disponíveis para a medição de propriedades reológicas. Pode-se citar: medidas de tensão de cisalhamento interfacial em tempo real, permitindo o estudo das propriedades em função do tempo, como elasticidade e viscosidade de monocamadas; fácil variação de frequência da tensão de cisalhamento, sem a necessidade de mudança de elementos do reômetro (como é o caso de alguns instrumentos de torsão); a deformação é medida diretamente da posição da haste magnetizada; e a temperatura e pressão de superfície podem ser alteradas sem a necessidade da mudança da geometria da célula. Desta forma, esperase que o ISR seja uma ferramenta capaz de realizar medições reológicas de modelos de surfactantes pulmonares.

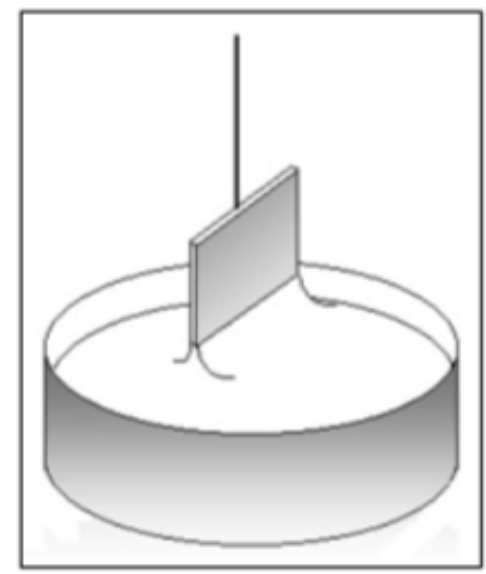

Figura 12: llustração do método da Placa de Wilhelmy

Benmekhbi \& Simon (2014) analisaram as limitações e aplicabilidade da técnica do reômetro de cisalhamento interfacial com sensor de agulha em amostras de surfactantes e compostos relacionados ao petróleo. Segundo os autores, os resultados obtidos não corresponderam às expectativas quando comparados aos dados da literatura, uma vez que as propriedades dos filmes não foram caracterizadas pelos dados recuperados dos experimentos de cisalhamento, apresentando, inclusive, comportamentos distintos durante seus experimentos. Desta forma, sugeriram que esta técnica não é adequada para tais medições (BENMEKHBI \& SIMON, 2014). 
Em 2014 e 2015, Hermans e colaboradores utilizaram o reômetro de cisalhamento interfacial em medidas reológicas de filmes de DPPC e surfactantes pulmonares, como Survanta e Curosurf, sob baixas frequências. Neste trabalho, foi notada a característica viscosa do Survanta, frente ao Curosurf e DPPC. Os sensores utilizados foram o anel de parede dupla (DWR, do inglês Double Wall Ring) e a agulha. Os autores sugerem maior sensibilidade deste último e os valores de G' e G" variaram entre $10^{-2}$ e $10^{-3} \mathrm{mN} / \mathrm{m}$ (Hermans \& Vermant, 2014) (HERMANS et al, 2015).

Segundo Hermans e colaboradores (2015), sob temperatura ambiente e pressões moderadas (cerca de $20 \mathrm{mN} / \mathrm{m}$ ), o DWR detecta somente G' e G" do Survanta. DPPC e Curosurf somente com ISR, sendo este, portanto, mais sensível. Desta forma, uma maior viscoelasticidade é esperada para o Survanta em relação do Curosurf e DPPC (HERMANS et al, 2015). 


\subsection{Tensiômetro de Gota}

O tensiômetro de gota se tornou largamente utilizado em laboratórios de pesquisa e controle de qualidade por atuarem na caracterização precisa de propriedades superficiais e interfaciais de fluidos em geral. Como principais atribuições, o instrumento pode ser utilizado para medições dinâmicas de ângulo de contato ao longo da contração e expansão da gota, molhabilidade de sólidos, tensão superficial, tensão de interfaces líquido/gás e líquido/líquido, além da reometria dilatacional (módulo viscoelástico). Para isso, o equipamento é acoplado ao software (Windrop) que analisa o perfil da gota através de algoritmos com parametrizações baseadas na Equação de Laplace (Equação 22). A partir do programa, as variáveis do experimento podem ser controladas, como frequência (até $10 \mathrm{hz}$ ) e volume da gota (ARASHIRO, E. Y.; DEMARQUETTE, 1999).

O princípio de funcionamento baseia-se na análise do perfil da gota como resposta à variação de seu volume a partir de imagens que são geradas por um microsópio acoplado. As gotas são formadas com volume pré-determinado pelo WINDROP, que controla o motor acoplado à seringa, além de fazer o tratamento dos dados obtidos. Além de ser utilizado em análises reológicas de lubrificantes, alimentos e cosméticos, o tensiômetro de gota é utilizado na caracterização de surfactantes e análises de capacidade de redução da tensão superficial, molhabilidade da superfície e até mesmo na quantidade de surfactante para saturar a superfície (ALEXANDROV, N.; MARINOVA, K. G.; DANOV, K. D.; INANOV, 2009).

A propriedade de interesse, ou seja, o módulo viscoelástico E, é obtida através da resposta da tensão sobre a variação de volume causada e, a partir da análise harmônica feita pelo software, os módulos real (E') e imaginário (E”) são determinados. As Figuras 13 e 14 mostram, respectivamente, o instrumento utilizado e a interface do Windrop para obtenção dos resultados. 


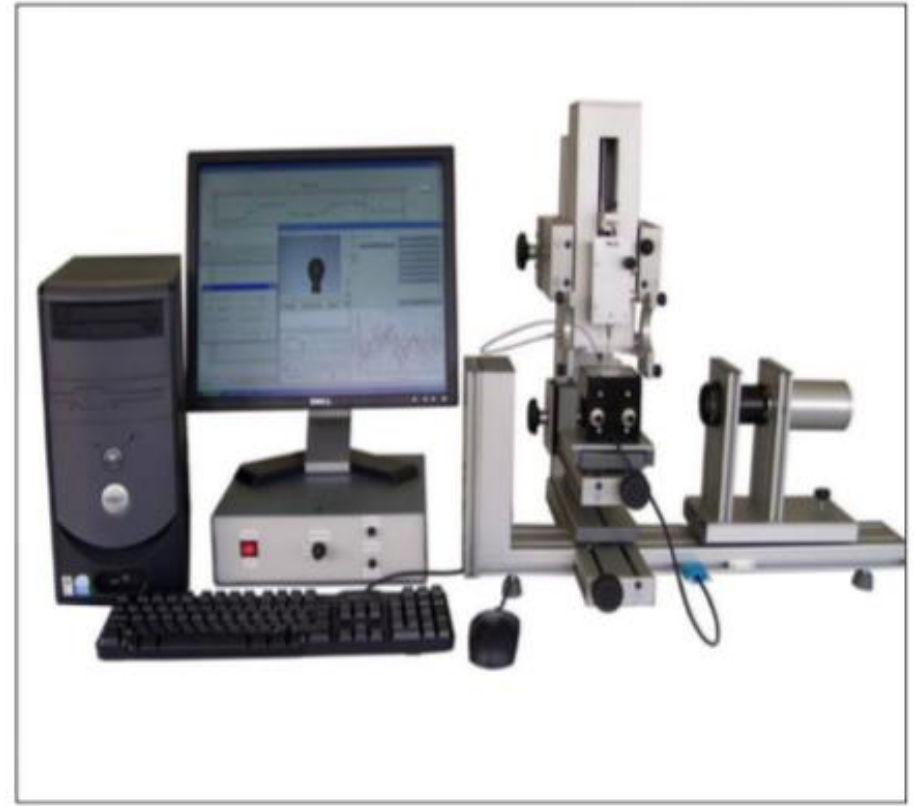

Figura 13: Teclis $^{\circledR}$ acoplado ao software Windrop

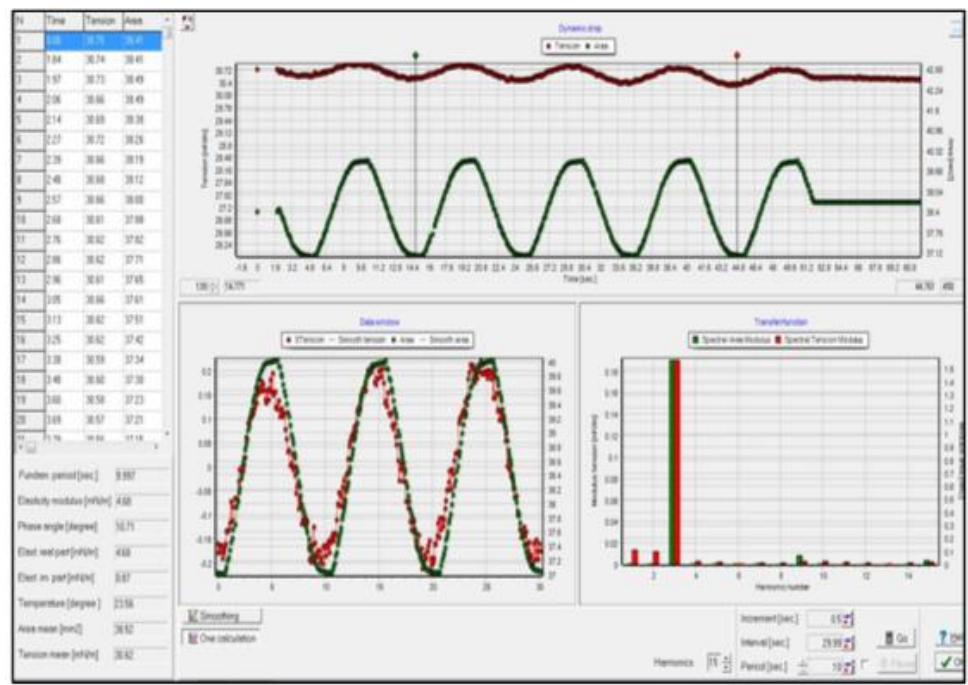

Figura 14: Interface do Windrop no tratamento dos dados obtidos. 


\section{$4 \quad$ Metodologia}

\subsection{Reologia de Cisalhamento}

As propriedades reológicas de cisalhamento foram investigadas utilizando um reômetro de cisalhamento interfacial ISR 400 (KSV, Finlândia) equipado com uma cuba de Langmuir de alta compressão (modelo KN1005 da KSV, Finlândia). Os modelos de surfactantes pulmonares utilizados foram Survanta (Abbvie, EUA), de concentração $25 \mathrm{mg} / \mathrm{mL}$, e Curosurf (Chiesi, Itália) de concentração 80 $\mathrm{mg} / \mathrm{mL}$, ambos obtidos comercialmente. As soluções preparadas em laboratório foram de DPPC 0,5 mg/mL, utilizando DPPC adquirido da Avanti Polar Lipids Inc. (Alabaster, $\mathrm{AL}$ ) e o solvente de espalhamento, o clorofórmio (Sigma-Aldrich, Brasil), DPPC:DPPG (70:30), utilizando DPPG adquirido da marca xyz (país) e DPPC:DPPG:Colesterol (70:20:10).

Inicialmente, a cuba de Langmuir de $\operatorname{Teflon}^{\circledR}(\mathrm{KSV}$, Finlândia) de área 587 $\mathrm{cm}^{2}$ foi preenchida com $293 \mathrm{~mL}$ de água destilada deionizada (resistividade de $18,2 \Omega / \mathrm{cm}$ e $\mathrm{pH} \sim 6,0$ ) como subfase de um sistema de filtragem Milli-Q (EMD, Milipore, MA). A cuba e as barreiras foram limpas com água, acetona e finalmente com água ultrapura Mili-Q. Um sugador foi utilizado para limpar poeira na superfície (ou sugar água da cuba) e o procedimento foi repetido até que o sistema fosse suficientemente limpo, gerando uma pressão de superfície menor que $1,0 \mathrm{mN} / \mathrm{m}$ após a compressão das barreiras.

Uma solução de $\mathrm{CaCl}_{2} 2 \mathrm{H}_{2} \mathrm{O}$ foi preparada a partir de $0,24 \mathrm{~g}$ do sal adicionado em $1 \mathrm{~L}$ de água deionizada Milli-Q. Uma alíquota de $10 \mu \mathrm{L}$ desta solução de $\mathrm{Ca}^{2+}$ foi adicionada à subfase e as medidas reológicas foram realizadas. Após, $10 \mu \mathrm{L}$ de amostra foram espalhados cuidadosamente ao longo da cuba gota a gota. Ambas as adições foram feitas com auxílio de microseringas Hamilton limpas com acetona, etanol e água. O tempo de estabilização do filme foi respeitado através da análise do gráfico de pressão de superfície x tempo (60 minutos para Survanta e 60 segundos para Curosurf) e, no caso do DPPC, 
esperou-se 10 minutos para a evaporação do clorofórmio. Representação esquemática do equipamento encontra-se na Figura 15.

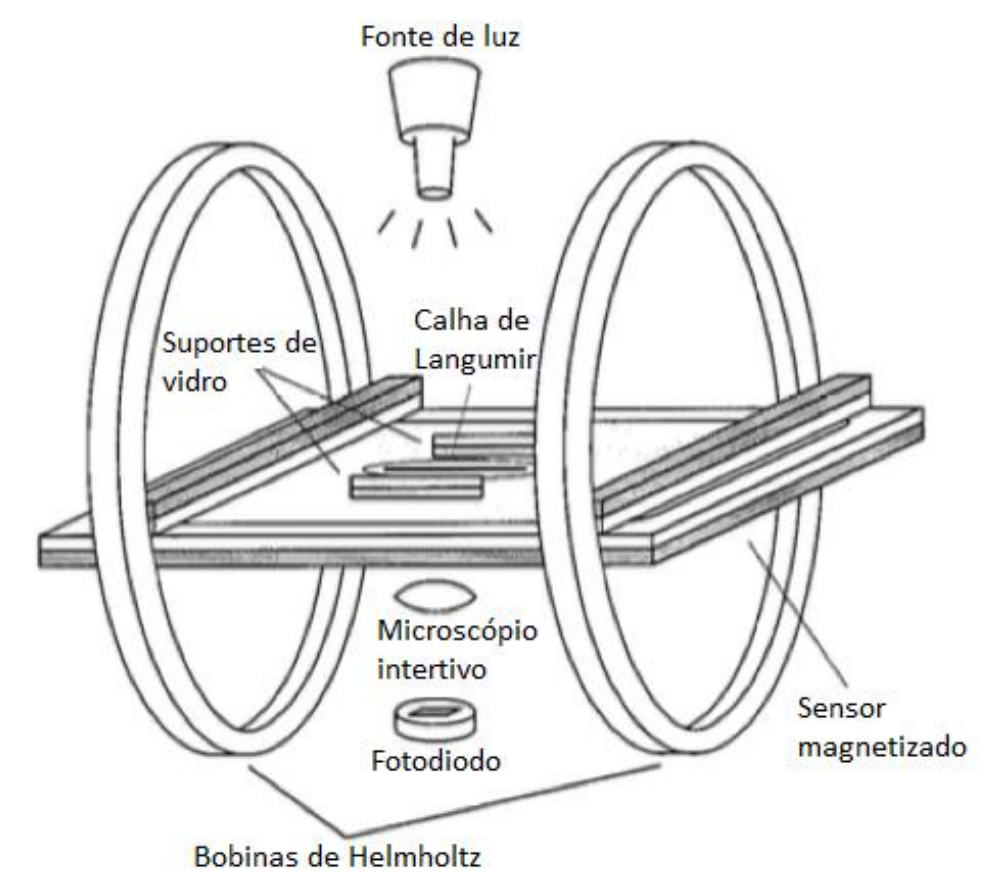

Figura 15: Representação esquemática do experimento (BROOKS et al., 1999)

Posteriormente, uma agulha (de 29,40 mm de comprimento, $0,4 \mathrm{~mm}$ de diâmetro e $0,0080 \mathrm{~g}$ de massa) foi posicionada na superfície da água na região central da cuba. Esta agulha possui uma das extremidades na cor branca, que foi posicionada no foco da câmera de microscópio (Navitar Inc.).

Uma varredura de amplitude de tensão foi realizada em frequência próxima de $0,1 \mathrm{~Hz}$ para determinação da faixa do Regime Viscoelástico Linear, o que significa que a estrutura do filme não foi alterada. Este fenômeno foi representado por valores constantes de G' e G" e termina com um valor crítico ao qual, acima dele, há variação de ambos os módulos.

Após as barreiras hidrofóbicas e simétricas de Teflon ${ }^{\circledR}$ foram fechadas a uma velocidade de $10 \mathrm{~mm} / \mathrm{min}$ até que fosse obtida uma pressão de superfície de $30 \mathrm{mN} / \mathrm{m}$, medida através de uma placa de Wilhelmy de filtro de papel que toca a interface, conectada a um sensor de pressão de superfície (KSV Nima 
Ltd., Finlândia). Medições em baixas pressões (de 0 a $10 \mathrm{mN} / \mathrm{m}$ ) também foram realizadas e medições acima de $30 \mathrm{mN} / \mathrm{m}$ colapsavam o filme. Após obtida a pressão, uma força magnética oscilatória foi aplicada através das bobinas de Helmholtz, magnetizando a agulha que flutua na interface ar-água. $O$ deslocamento horizontal da agulha foi capturado por meio do microscópio, que cisalhou o filme sob uma faixa de frequências de 0,5 até $2,0 \mathrm{~Hz}$ para determinação dos módulos elástico (G') e viscoso (G') e a amplitude da tensão aplicada foi $0,5 \mathrm{~V}$.

A partir destes valores, tan $\delta$ também foi calculada. $O$ equipamento é disposto sobre uma mesa antivibração para minimizar os efeitos vibracionais da bancada. $\mathrm{O}$ experimento foi realizado sob temperatura de $30^{\circ} \mathrm{C}$. Os comandos foram realizados através de interface da cuba com um computador utilizando o software KSV Server (KSV Nima Ltd., Finlândia). 


\subsection{Reologia Dilatacional}

Na análise do módulo viscoelástico dilatacional do Survanta e Curosurf, o tensiômetro de gota Teclis Tracker - H foi utilizado. Em todas as medições, uma cubeta de quartzo de $25 \mathrm{~mL}$ foi utilizada somente como suporte para ejetar a gota. O controle de formação da gota e o controle de variação de seu volume foram feitos através da interface do software com o motor acoplado Tracker e as medições iniciaram após 2 minutos de espera após a formação da gota.

O Survanta também foi extraído diretamente do frasco com auxílio de seringa e formou-se a gota com $8 \mu \mathrm{L}$ com variação de volume de $10 \%$. As medições iniciaram após $1 \mathrm{~h}$ de espera depois de formada a gota. A gota rompia em volumes maiores que $8 \mu \mathrm{L}$ e quando a variação de seu volume era maior que $10 \%$.

O procedimento foi similar com o Curosurf, com volume da gota de $4 \mu \mathrm{L}$ com variação de $5 \%$ e após a formação da gota, esperou-se 10 minutos para garantir que o surfactante aderiu a interface. Volumes maiores que $4 \mu \mathrm{L}$ e variações de volume maiores que $5 \%$ rompiam a gota.

No Windrop, como valores de entrada, foram utilizados a densidade da gota como aproximadamente da água $\left(0,99 \mathrm{~g} / \mathrm{cm}^{3}\right)$ e da fase $a r=0,00125 \mathrm{~g} / \mathrm{cm}^{3}$.

Com o Survanta, a medição ocorreu com frequência de $0,1 \mathrm{~Hz}$ e com o Curosurf, 0,1 e $0,5 \mathrm{~Hz}$. 


\section{$5 \quad$ Resultados e Discussões}

\subsection{Valores de G' e G” em função da frequência}

Os módulos de armazenamento (G') e perda (G') foram determinados na faixa de 0,5 a $2,0 \mathrm{~Hz}$ e cinco medidas foram feitas por frequência. A Tabela 4 mostra a média dos valores obtidos para a solução de $\mathrm{Ca}^{2+}$.

\begin{tabular}{|l|c|c|c|c|c|}
\hline Freq. (Hz) & $\mathbf{0 , 6 3}$ & $\mathbf{0 , 8}$ & $\mathbf{1}$ & $\mathbf{1 , 2 6}$ & $\mathbf{1 , 5 9}$ \\
\hline $\mathbf{G}^{\prime}(\mathbf{m N} / \mathbf{m})$ & $3,3 \times 10^{-4}$ & $5,4 \times 10^{-4}$ & $7,3 \times 10^{-4}$ & $1,1 \times 10^{-3}$ & $1,7 \times 10^{-3}$ \\
\hline $\mathbf{G '}(\mathbf{m N} / \mathbf{m})$ & $1,80 \times 10^{-4}$ & $3,1 \times 10^{-4}$ & $3,7 \times 10^{-4}$ & $2,70 \times 10^{-4}$ & $5,0 \times 10^{-5}$ \\
\hline
\end{tabular}

Tabela 4: Valores de G' e G" na interface ar-água de uma solução de $\mathrm{Ca}^{2+} 1,63.10^{-3}$ mol.L-1

Os parâmetros foram determinados com a solução de $\mathrm{Ca}^{2+}$ sem amostra na interface acima da mesma. Tal adição de íons Cálcio é importante para simular melhor o ambiente fisiológico do surfactante, inclusive, para o funcionamento das proteínas surfactantes nos alvéolos pulmonares. Espera-se que a viscoelasticidade aumente com a adição das amostras. Desta forma, tal medição também funcionou como "branco".

Nas condições de trabalho, a solução de $\mathrm{Ca}^{2+}$ mostrou-se elástica, tendo este comportamento agravado com o aumento da frequência. Valores muito baixos $\left(10^{-5}\right)$ puderam ser detectados pelo equipamento, mostrando sua sensibilidade. O Gráfico 1 mostra os valores de G' (representado por $\square$ ) e G" (representado por $\triangle$ ) obtidos na faixa de frequência de 0,6 a 1,6 Hz. Nota-se característica elástica da solução em toda a faixa de frequência analisada. 


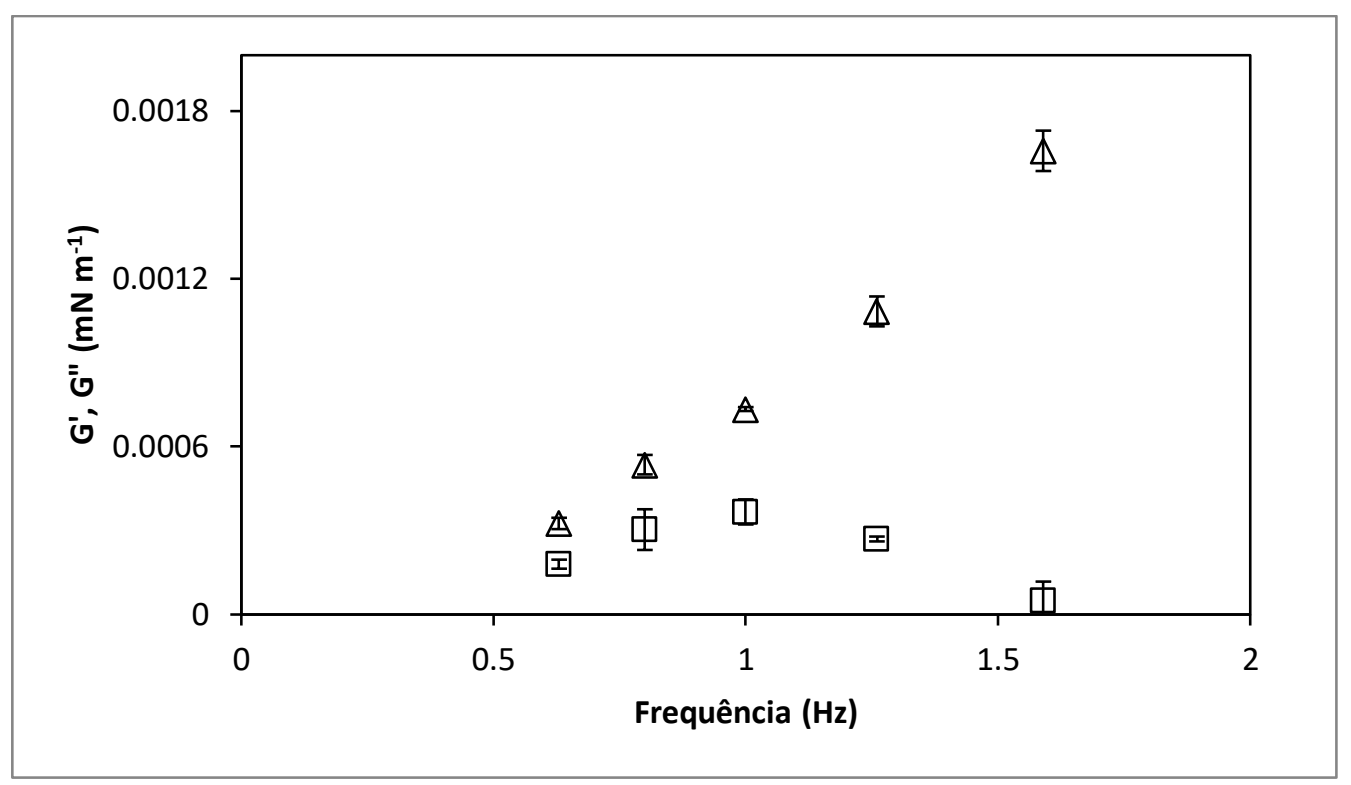

Gráfico 1: G' $(\square)$ e G" $(\triangle)$ para a solução de Ca ${ }^{2+}$ de concentração $1,63.10^{-3} \mathrm{~mol} \mathrm{~L}^{-1}$ na interface ar/água.

Com a adição de Survanta, novos valores de G' e G" foram obtidos na faixa de 0,6 a $1,6 \mathrm{~Hz}$. Foi percebida viscoelasticidade relativamente alta, conforme já constatado na literatura (HERMANS, ELINE; BHAMLA, M. S; KAO, P; FULLER, G. G; VERMANT, 2015). Em toda a faixa de frequência de estudo, seu módulo viscoso é maior que o elástico (justificando seu comportamento viscoso), sendo a diferença acentuada sob maiores frequências. No Gráfico 2, nossos resultados (representados pelos símbolos $\boldsymbol{\Delta}$ para G' e $\mathbf{\square}$ para G") são apresentados juntamente com o resultado da literatura (representados pelos símbolos $\triangle$ para G' e $\square$ para G"), que mostram o comportamento viscoso do Survanta também sob baixas frequências (HERMANS, ELINE; BHAMLA, M. S; KAO, P; FULLER, G. G; VERMANT, 2015).

Survanta pode não ser ideal sob altas frequências respiratórias, visto que seu módulo viscoso tende a aumentar e seu módulo elástico ser baixo. Tanto nossos resultados quanto os resultados da literatura (HERMANS, ELINE; BHAMLA, M. S; KAO, P; FULLER, G. G; VERMANT, 2015) se mostraram no limite da técnica apresentada pelo manual do instrumento. Sua alta viscoelasticidade pode ser detectada, inclusive, sob reômetros de cisalhamento com diferentes geometrias, como o DWR (HERMANS, ELINE; BHAMLA, M. S; KAO, P; FULLER, G. G; VERMANT, 2015). Entende-se que a quantidade de 
colesterol presente neste surfactante seja uma das responsáveis pela alta viscosidade como pode ser demonstrado comparando-se amostras de DPPC/DPPG e DPPC/DPPG/Colesterol a seguir.

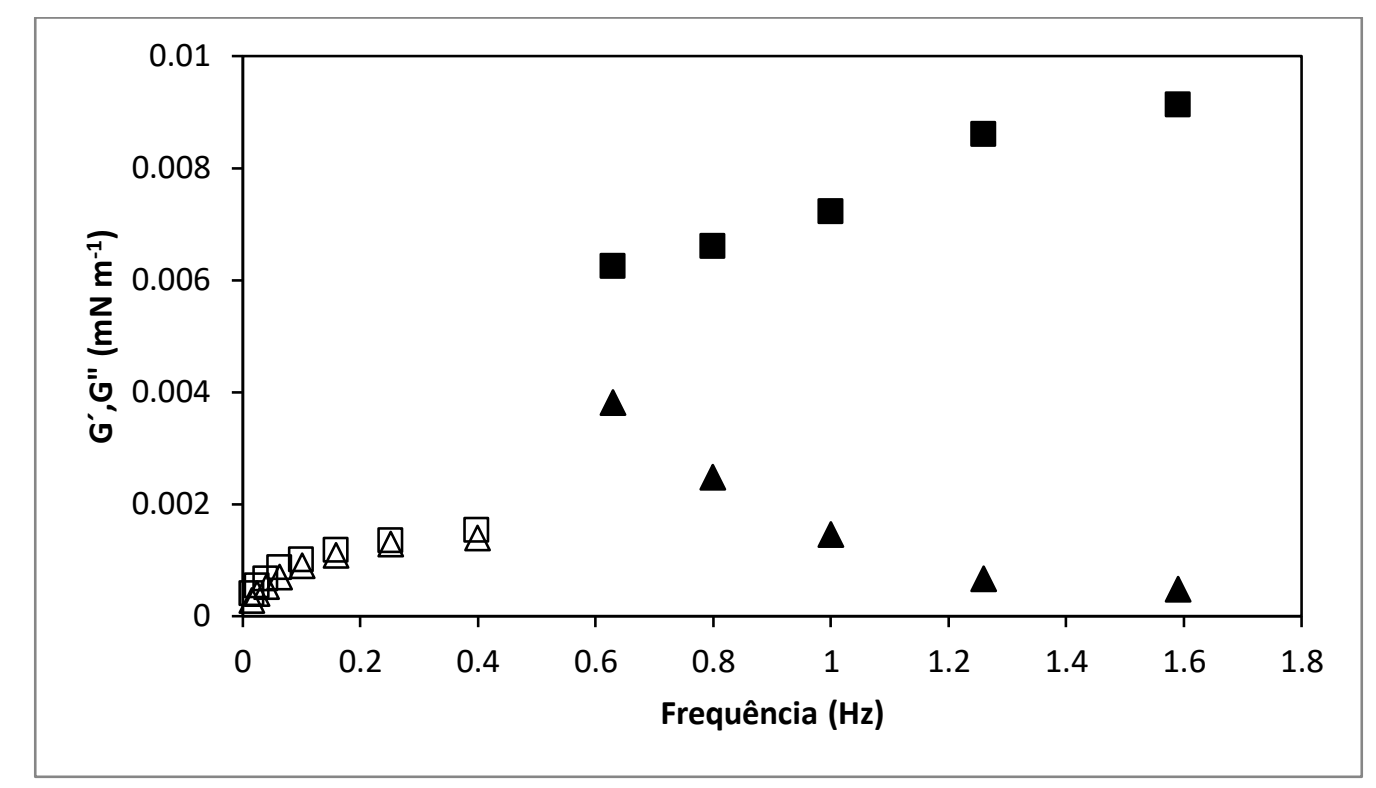

Gráfico 2: G' e G" do Survanta com nossos dados $(\boldsymbol{\Delta}$ e $\mathbf{\square})$ e da literatura $(\triangle \mathrm{e} \square)$.

Curosurf apresentou comportamento contrário ao Survanta, visto que em toda a faixa de frequência analisada comportou-se elasticamente, sugerindo que o surfactante possa ter uma interessante aplicação em atletas. O baixo módulo viscoso do Curosurf é cerca de 20 vezes menor que Survanta em altas frequências e o módulo elástico é alto em altas frequências. O fato de não haver colesterol em sua composição pode ser um dos fatores que leva à alta elasticidade. O Gráfico 3 mostra nossos resultados (representados pelos símbolos $\Delta$ para G' e $\boldsymbol{\square}$ para G") e os resultados da literatura (representados pelos símbolos $\triangle$ para G') (HERMANS, ELINE; BHAMLA, M. S; KAO, P; FULLER, G. G; VERMANT, 2015) 


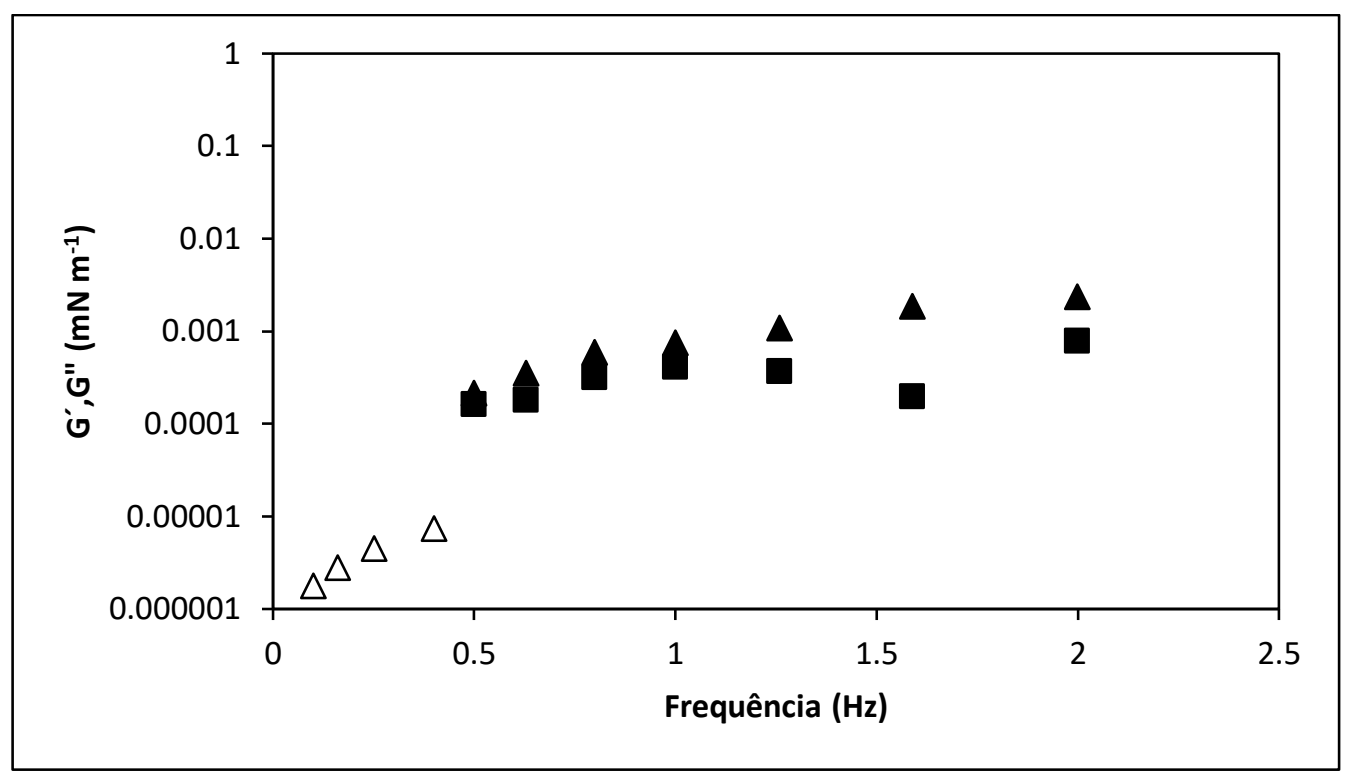

Gráfico 3: Valores de G' ( $\Delta$ para nossos resultados e $\triangle$ para os resultados da literatura) e G"(घ) do Curosurf. Sob baixas frequências, seus módulos elástico e viscoso são próximos.

O DPPC apresentou comportamento particular em nossos experimentos, possuindo características intermediárias entre Survanta e Curosurf. Sob baixas frequências (menores que $1 \mathrm{~Hz}$ ), seu módulo viscoso é maior que o módulo elástico, tendo como resultado aparente o comportamento viscoso. Sob frequências maiores, um comportamento contrário é percebido. No Gráfico 4 , nossos resultados (representados pelos símbolos $\mathbf{\Delta}$ para G' e $\mathbf{\square}$ para G") são apresentados junto com os resultados obtidos na literatura (representados pelos símbolos $\triangle$ para G' e $\square$ para G") (HERMANS, ELINE; BHAMLA, M. S; KAO, P; FULLER, G. G; VERMANT, 2015), que também mostraram a característica viscosa do DPPC sob baixas frequências. A ordem de grandeza obtida em Hermans e colaboradores (2015) por outro lado, foi 100 vezes menor. Mesmo obtido a frequências mais baixas, acreditamos que essa variação se deve a fatores como características da agulha e sensibilidade da técnica para cada equipamento usado. 


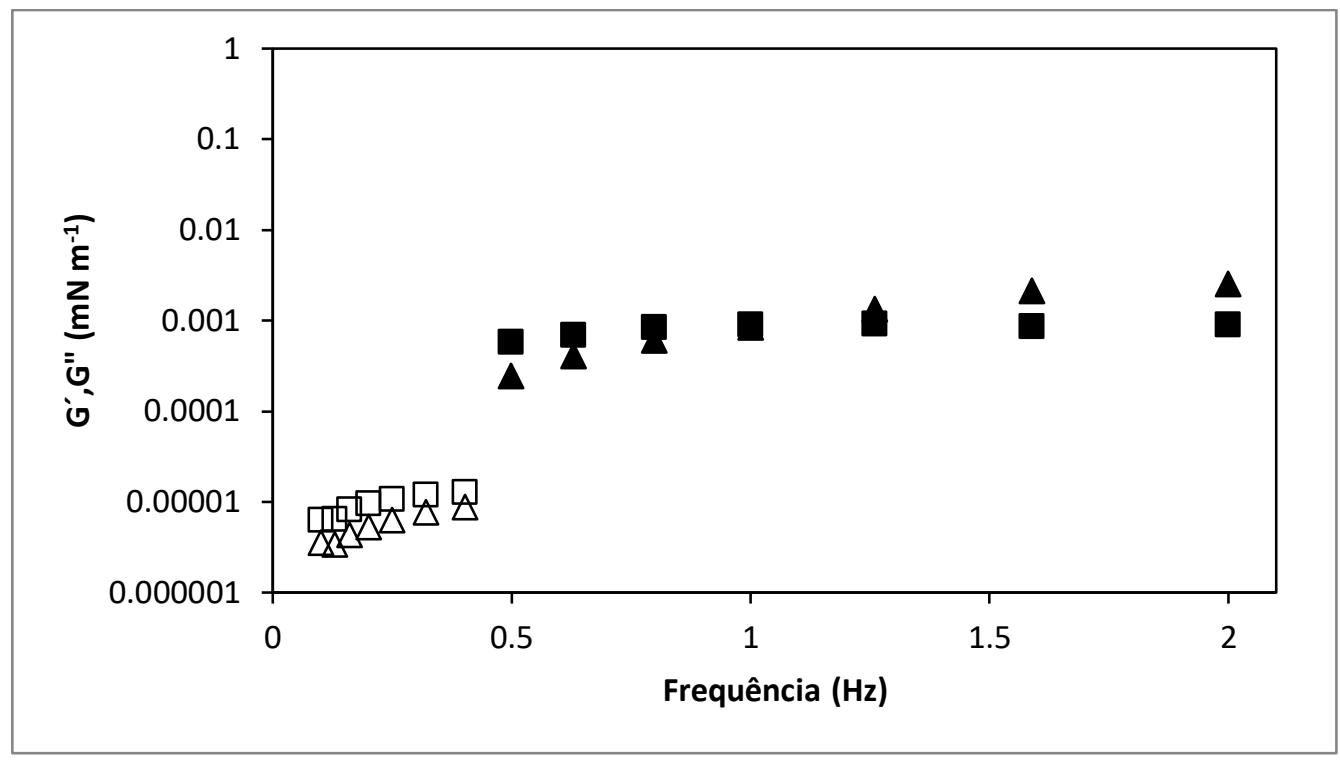

Gráfico 4: G' e G" do DPPC com nossos dados ( $\boldsymbol{\Delta}$ e $\boldsymbol{\square})$ e da literatura $(\triangle \mathrm{e} \square)$. Percebe-se a característica viscosa do DPPC em ambos trabalhos e mudança de comportamento sob frequências maiores, com nossos resultados.

$\mathrm{Na}$ busca de informações sobre a viscoelasticidade de modelos de surfactantes pulmonares, a mistura DPPC:DPPG parece ser adequada devido à adição de mais um tipo de fosfolipídio, que torna o modelo mais completo. $A$ adição de Colesterol nesta mistura foi realizada para investigar sua contribuição na viscoelasticidade da amostra (e fazer uma comparação) com Survanta e Curosurf). Os módulos G' e G" foram obtidos conforme mostrado na Tabela 5.

DPPC:DPPG (70:30)

\begin{tabular}{|c|c|c|c|}
\hline Freq. (Hz) & $\mathbf{0 , 6 3}$ & $\mathbf{1 , 2 6}$ & $\mathbf{2}$ \\
\hline G' (mN/m) & $7,0 \times 10^{-4}$ & $7,4 \times 10^{-3}$ & $9,7 \times 10^{-3}$ \\
\hline G'(mN/m) & $1,4 \times 10^{-3}$ & $4,0 \times 10^{-4}$ & $4,6 \times 10^{-3}$ \\
\hline
\end{tabular}

DPPC:DPPG:COL (70:20:10)

\begin{tabular}{|c|c|c|c|}
\hline Freq. (Hz) & $\mathbf{0 , 8 0}$ & $\mathbf{1 , 2 6}$ & $\mathbf{1 , 5 9}$ \\
\hline $\mathbf{G}$ ( $\mathbf{m N} / \mathbf{m})$ & $3,2 \times 10^{-3}$ & $9,0 \times 10^{-3}$ & $1,0 \times 10^{-2}$ \\
\hline $\mathbf{G}{ }^{\prime \prime}(\mathbf{m N} / \mathbf{m})$ & $3,2 \times 10^{-3}$ & $6,4 \times 10^{-4}$ & $1,5 \times 10^{-3}$ \\
\hline
\end{tabular}

Tabela 5: G' e G" para as misturas de DPPC:DPPG (70:30) e DPPC:DPPG:COL (70:20:10). 
Comparando os dados da Tabela acima com os valores obtidos para o DPPC, percebe-se que houve aumento da elasticidade da mistura e redução de sua viscosidade em toda a faixa de frequência estudada somente com adição de DPPG. Essa mudança pode ter sido causada devido a carga do DPPG. A elasticidade da mistura tornou-se ainda maior que a do Curosurf, surfactante comercial, que também não possui colesterol em sua composição.

A adição de colesterol aumentou cerca de 60 vezes o valor de G" (responsável pela viscosidade) da mistura em nossos experimentos. Sob frequências maiores, tal aumento também ocorre, mas não é tão significativo. Analogamente, podemos sugerir que o colesterol aumenta a viscosidade de modelo de surfactante pulmonar (tanto em baixas quanto em altas frequências respiratórias), não sendo o ideal em geral. Mas, por exemplo, deve ser prejudicial em atletas cujos alvéolos pulmonares expandem-se acima do normal, necessitando de elasticidade.

A mistura DPPC:DPPG:COL tornou-se mais viscosa que DPPC:DPPG, aparentando não ser um modelo adequado, visto seu aumento de viscosidade. Para estudos com modelos de surfactantes pulmonares, a mistura DPPC:DPPG pode ser mais adequada visto que o DPPG aumentou a elasticidade da amostra, tornando-se mais importante em baixas frequências, onde o DPPC mostra características viscosas.

As amostras analisadas possuíam viscoelasticidades suficientemente altas para serem avaliadas no ISR, estando dentro dos limites de sensibilidade do equipamento, não havendo necessidade dos resultados serem corrigidos para 0 arraste da subfase (HERMANS, ELINE; BHAMLA, M. S; KAO, P; FULLER, G. G; VERMANT, 2015). 


\subsection{O Módulo Dinâmico e o Regime Viscoelástico}

Conforme Equação 13, o módulo G também foi determinado e analisado de forma dinâmica em função da frequência de estudo. Nossos resultados apresentaram-se no regime viscoelástico linear. Assim, aplicando uma frequência mais alta, permitiu-se menores rearranjos moleculares na interface ar-água, e, portanto, uma maior resistência à deformação elástica e viscosa. Este regime traz maior confiabilidade aos nossos resultados.

Para a solução de íons Cálcio e amostras de Curosurf, DPPC, DPPC:DPPG e DPPC:DPPG:COL, os valores de $G$ variaram linearmente com a frequência. Os Gráficos 5, 6 e 7 (representado por $\square$ para nosso G e por $\Delta$ para G obtido por Hermans e colaboradores, 2015) mostram, respectivamente, os valores de $G$ para a solução de íons cálcio e amostras de Curosurf, DPPC, DPPC:DPPG e DPPC:DPPG:COL. A Tabela 6 mostra os resultados para as duas últimas misturas.

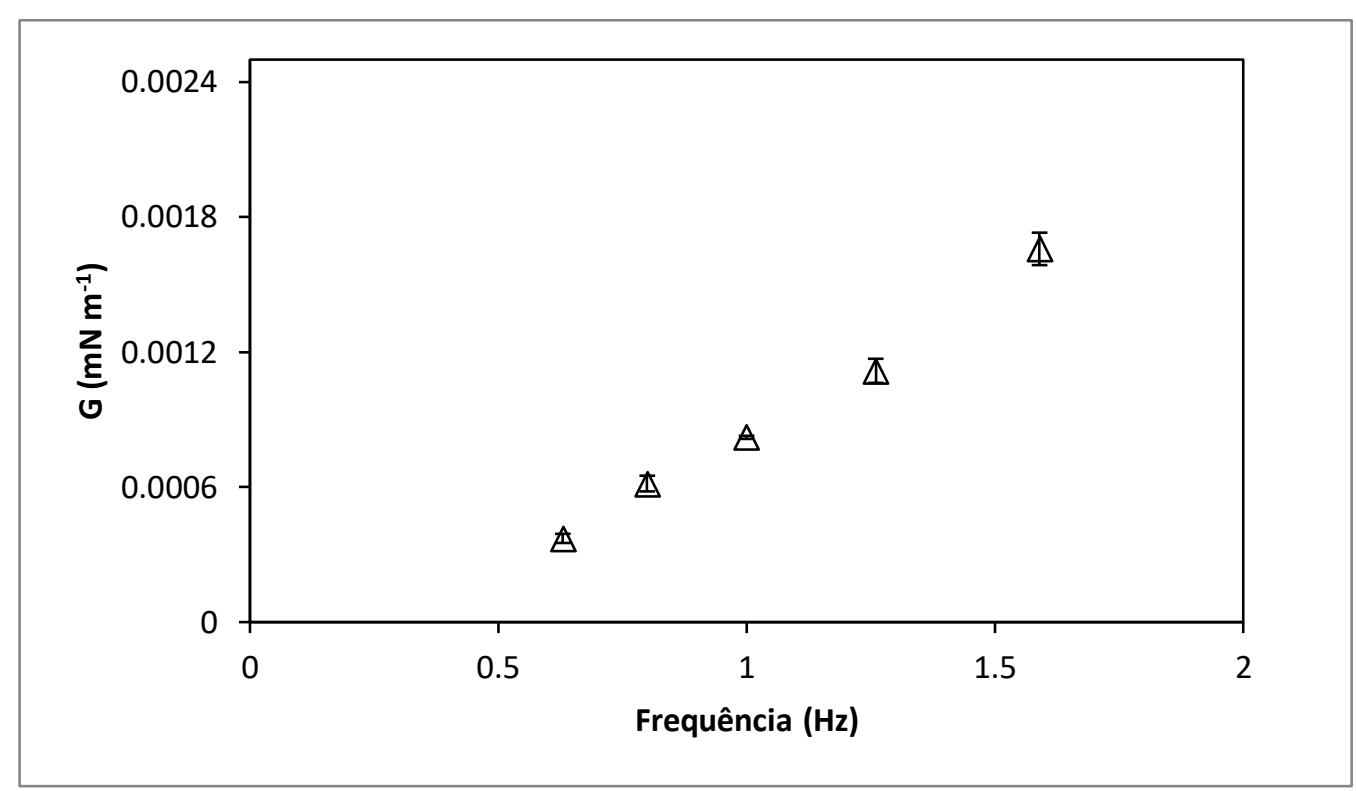

Gráfico 5: Relação entre $\mathrm{G}$ da solução de $\mathrm{Ca}^{2+} \mathrm{e}$ a frequência. 


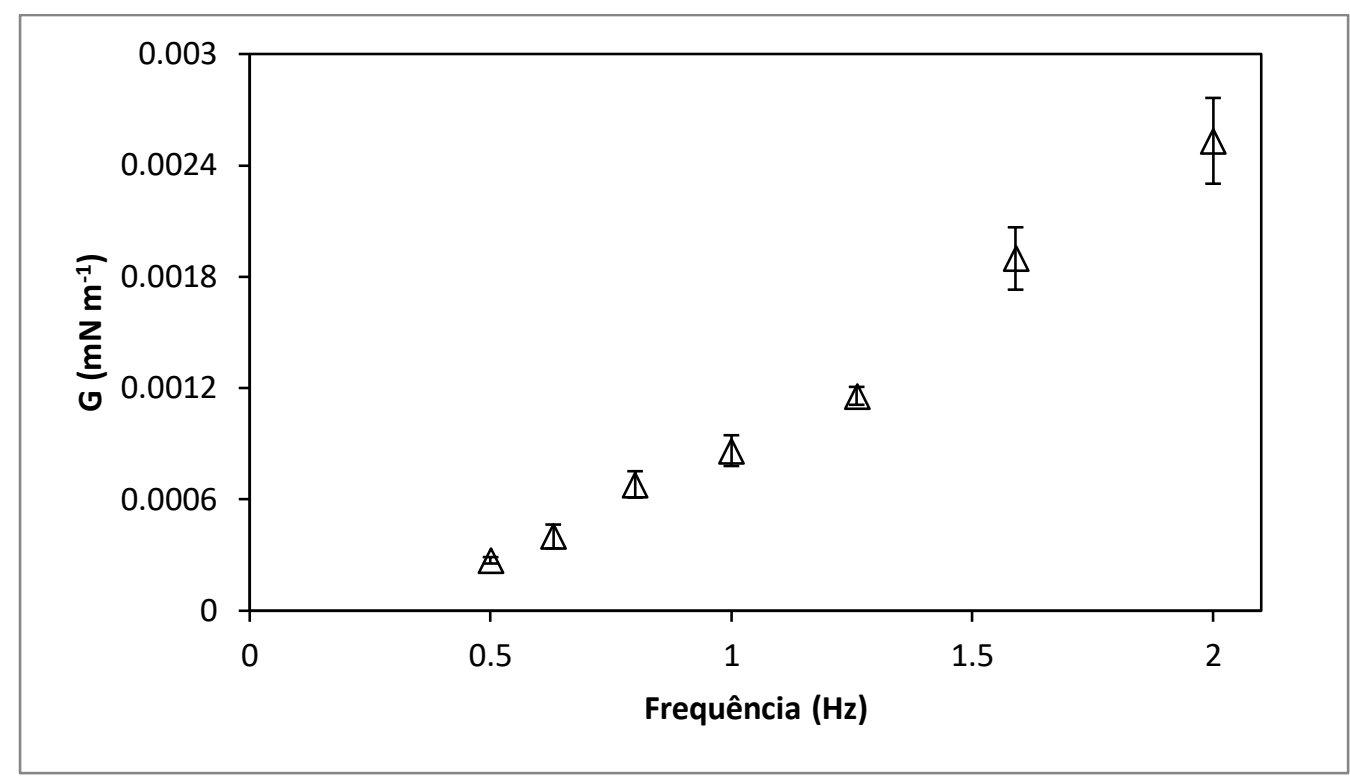

Gráfico 6: Relação entre G do Curosurf e a frequência.

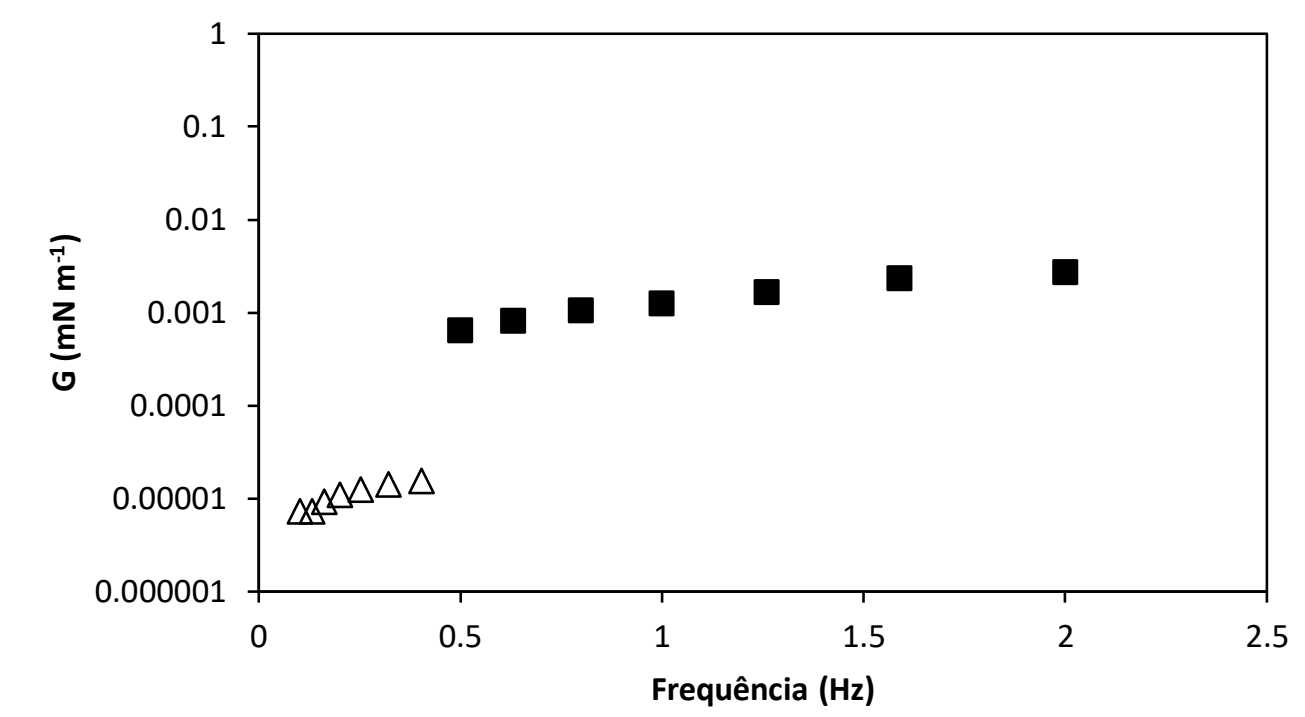

Gráfico 7: Relação entre G do DPPC e a frequência, com nossos resultados (ם) e da literatura $(\triangle)$. 
$D P P C: D P P G(70: 30)$

\begin{tabular}{|c|c|c|c|}
\hline Freq. (Hz) & $\mathbf{0 , 6 3}$ & $\mathbf{1 , 2 6}$ & $\mathbf{2}$ \\
\hline $\mathbf{G}(\mathbf{m N} / \mathbf{m})$ & $1,6 \times 10^{-3}$ & $7,5 \times 10^{-3}$ & $1,0 \times 10^{-2}$ \\
\hline
\end{tabular}

DPPC:DPPG:COL (70:20:10)

\begin{tabular}{|c|c|c|c|}
\hline Freq. (Hz) & $\mathbf{0 , 8 0}$ & $\mathbf{1 , 2 6}$ & $\mathbf{1 , 5 9}$ \\
\hline $\mathbf{G}(\mathbf{m N} / \mathbf{m})$ & $4,5 \times 10^{-3}$ & $9,1 \times 10^{-3}$ & $1,0 \times 10^{-2}$ \\
\hline
\end{tabular}

Tabela 6: Módulo dinâmico interfacial das misturas de DPPC:DPPG com e sem colesterol. Os valores apresentam-se no Regime Viscoelástico Linear trazendo confiabilidade e sentido físico para nossos resultados.

No Gráfico 8, os resultados obtidos são mostrados abaixo junto com os dados obtidos em frequências mais baixas na literatura. Nossos valores de $G$ são representados por $\boldsymbol{\Delta}$ e os dados da literatura, por $\mathbf{a}$ (HERMANS, ELINE; BHAMLA, M. S; KAO, P; FULLER, G. G; VERMANT, 2015). A regressão linear dos nossos valores de $G$ com a frequência não apresentou um coeficiente de correlação satisfatório para se definir como regime viscoelástico linear. A maior viscoelasticidade medida pode ser justificada pela relativa instabilidade do Survanta, notada ao longo da experiência no nosso laboratório.

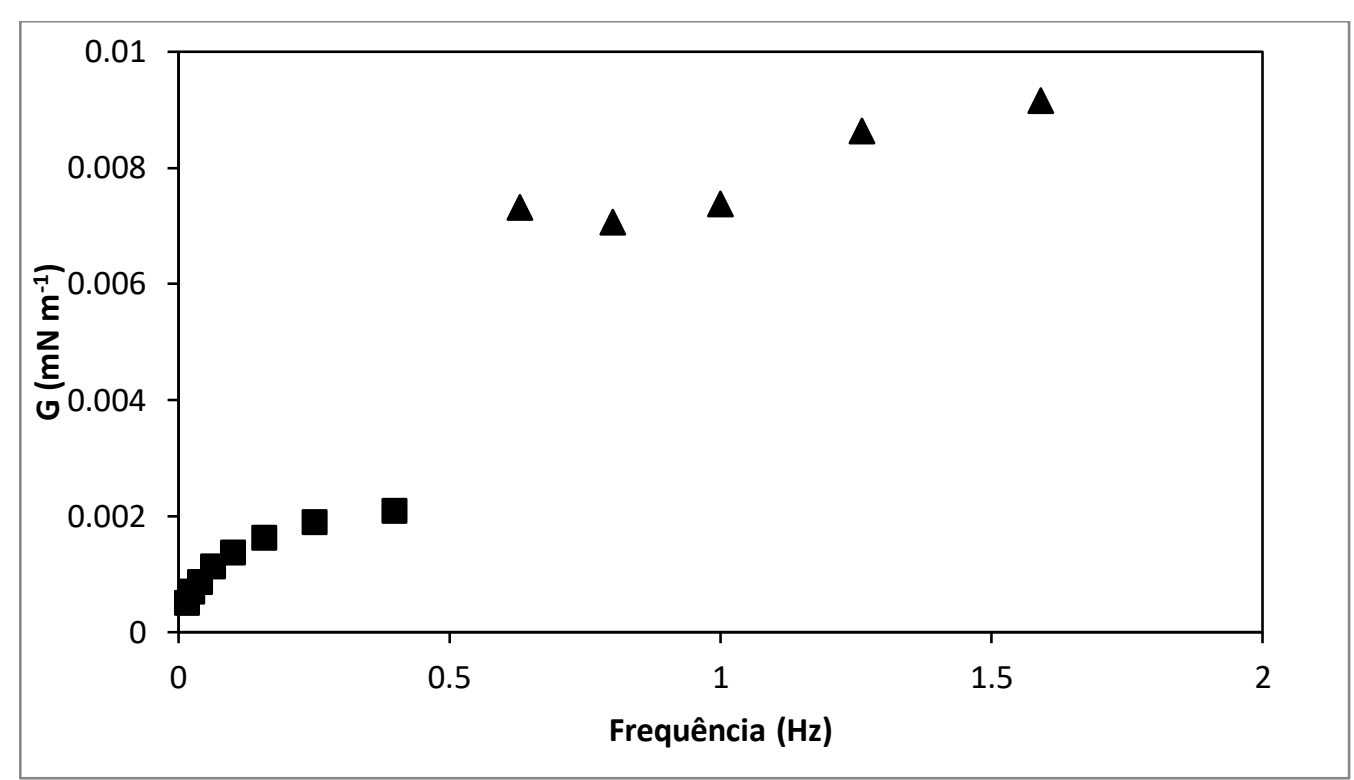

Gráfico 8: Relação entre G do Survanta e a frequência, com nossos resultados $(\boldsymbol{\Lambda})$ e da literatura $(\mathbf{\square})$.

\subsection{Valores de $\tan \delta$ em função da frequência}


Através da Equação 19, tan $\delta$ pode ser calculada em função da frequência do experimento. Os Gráficos 9, 10, 11 e 12 foram construídos através dos resultados obtidos e facilitam a visualização do comportamento das amostras (solução de $\mathrm{Ca}^{2+}$, Curosurf, Survanta e DPPC, respectivamente) ao longo da frequência, de acordo com resultados do item 5.1. A Tabela 7 mostra os valores para as amostras de DPPC:DPPG (70:30) e DPPC:DPPG:Colesterol (70:20:10).

Os cálculos obtidos para a amostra de solução de $\mathrm{Ca}^{2+}$ são mostrados no Gráfico 9. Em toda a faixa de frequência estudada, os valores de $\tan \delta$ são menores que 1, mostrando seu comportamento elástico. Comportamento similar foi obtido para a amostra de Curosurf, conforme item 5.1, cujos resultados dos cálculos são mostrados no Gráfico 12.

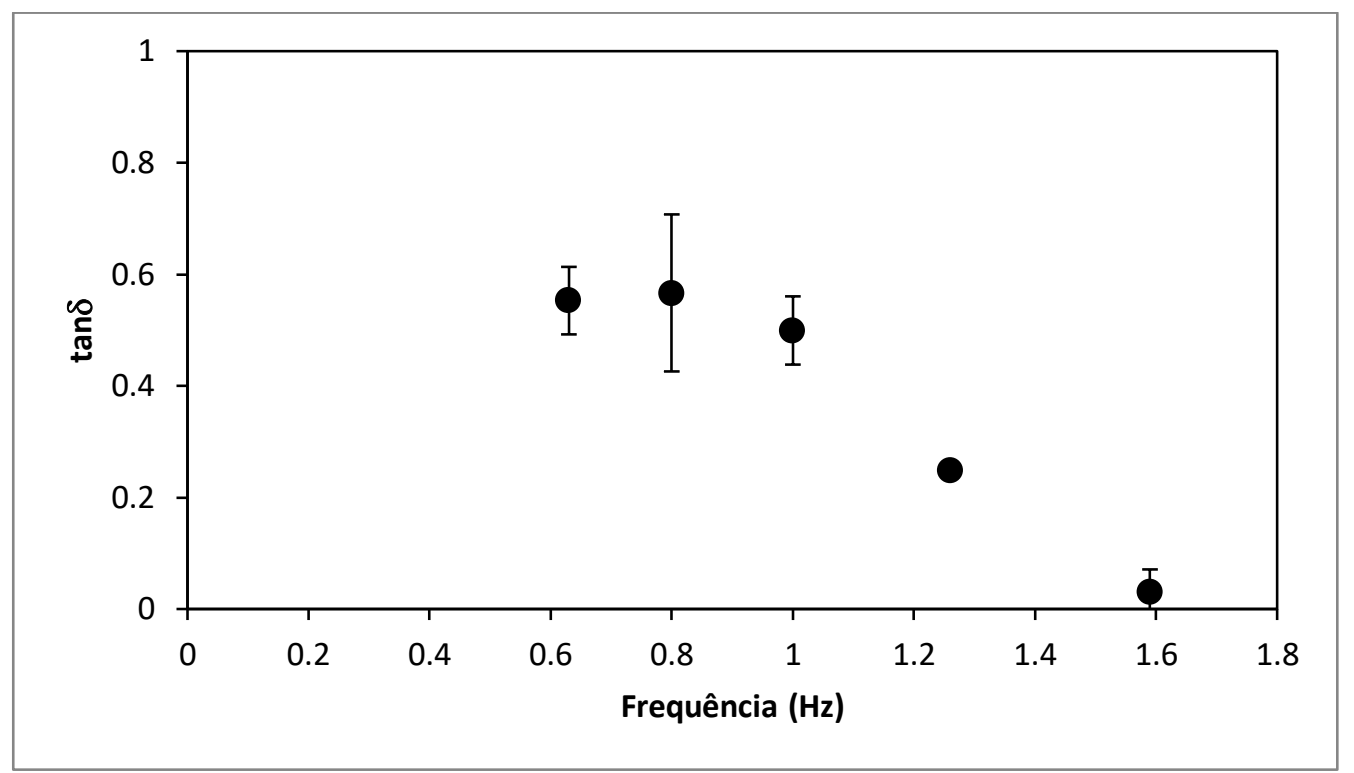

Gráfico 9: $\tan \delta$ da solução de $\mathrm{Ca}^{2+}$, mostrando característica elástica ao longo de toda a frequência estudada. 


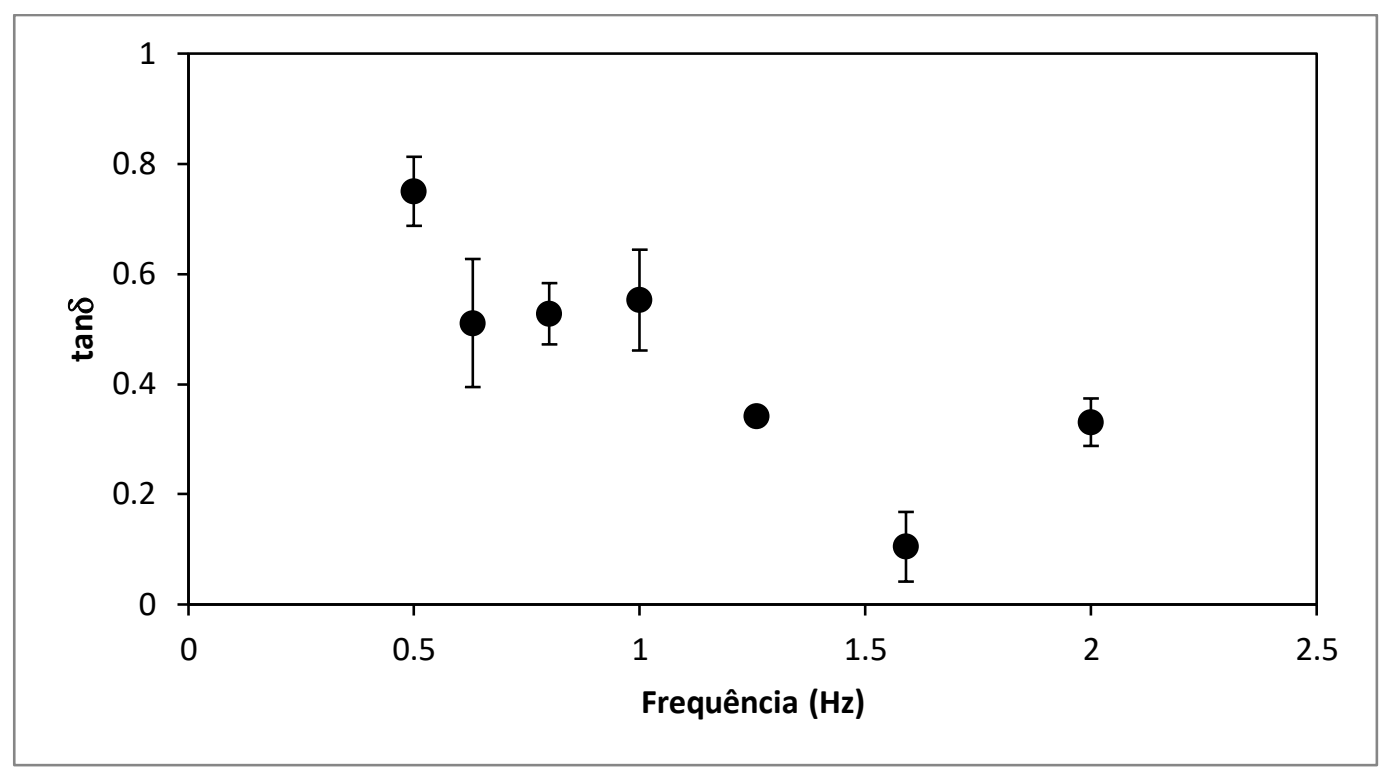

Gráfico 10: $\tan \delta$ do Curosurf, mostrando sua característica elástica ao longo de toda faixa de frequência estudada.

O comportamento viscoso do Survanta $(\tan \delta>1)$ é percebido ao longo de toda a faixa de frequência de interesse, cujos resultados dos cálculos são mostrados no Gráfico 11. Nota-se o aumento da viscosidade conforme aumentase a frequência. O Gráfico 12 mostra os resultados de tanઈ para o DPPC. Com a mudança da $\tan \delta$ ao longo da frequência, pode-se visualizar o ponto em que este parâmetro se torna menor que 1 , caracterizando visualmente 0 comportamento intermediário do DPPC. Desta forma, pode-se visualizar que o DPPC se apresenta elástico em frequências maiores que 1,2 Hz.

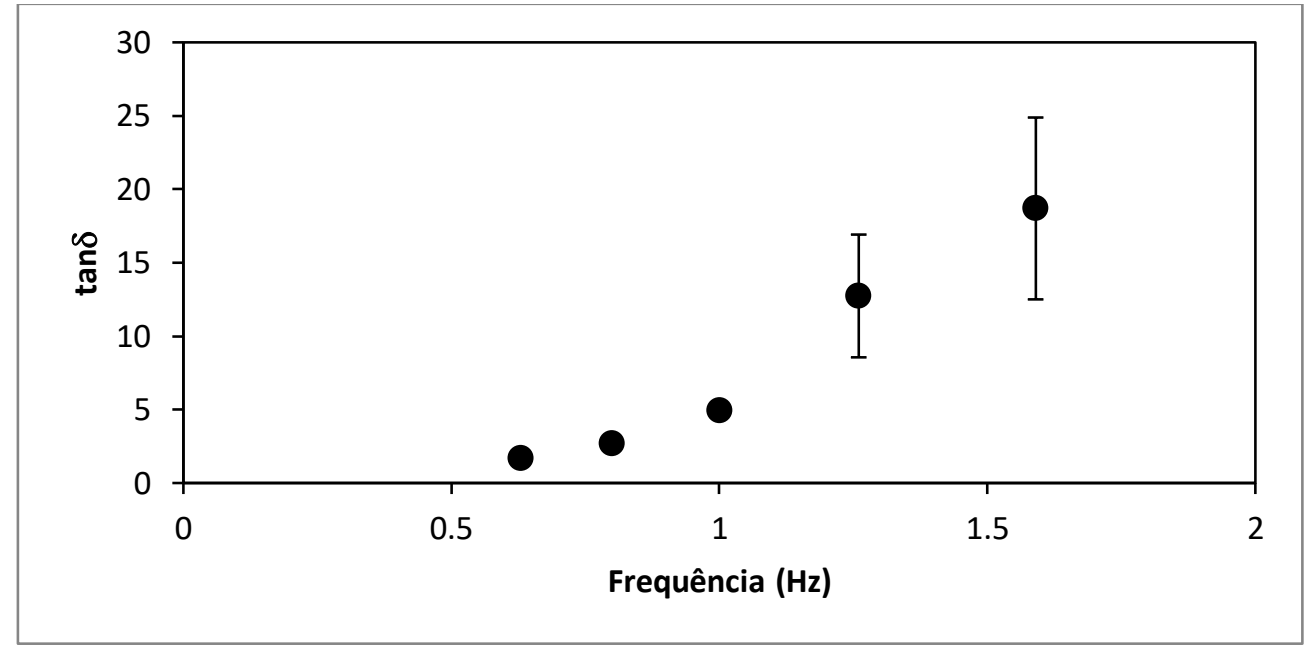

Gráfico 11: $\tan \delta$ do Survanta, mostrando sua característica viscosa ao longo de toda a faixa de frequência estudada. 


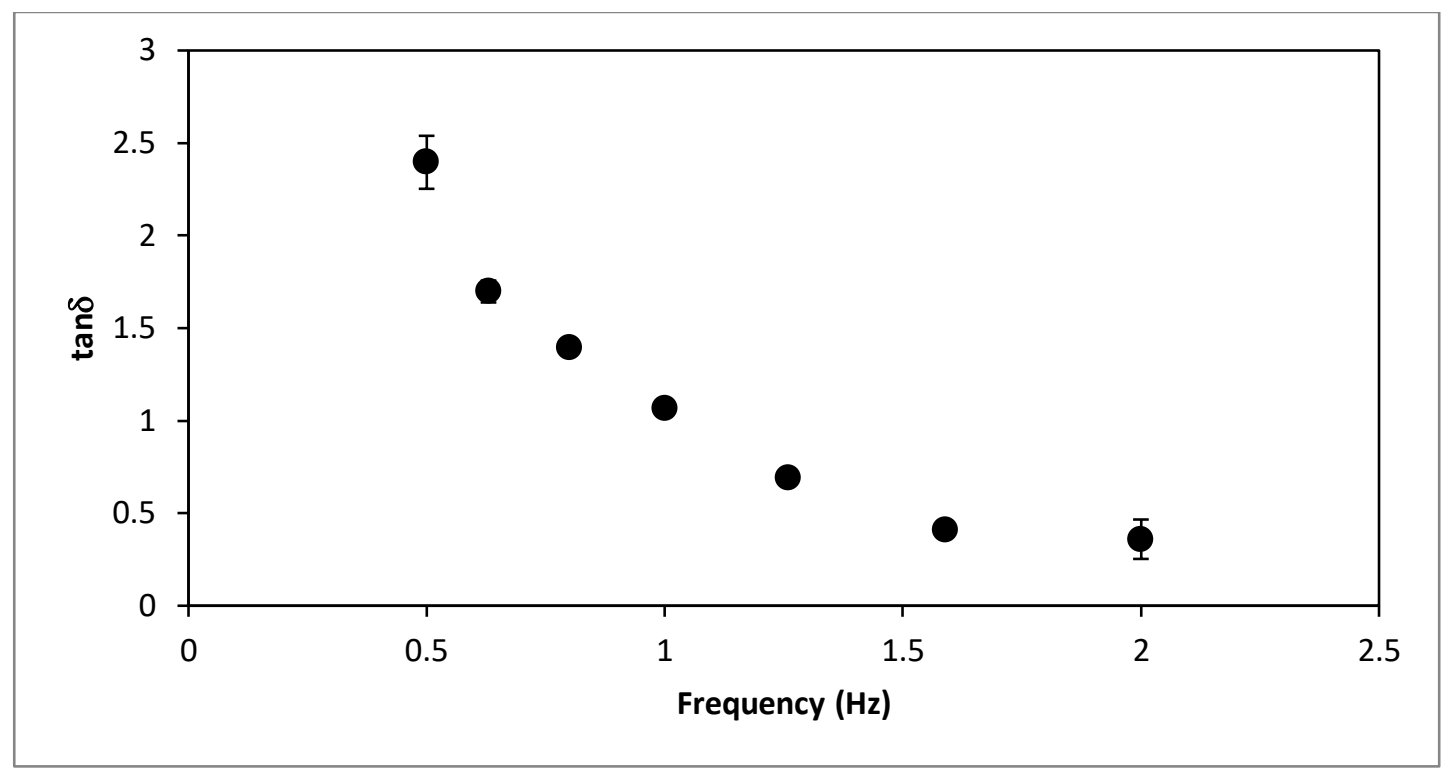

Gráfico 12: $\tan \delta$ do DPPC, mostrando sua mudança de comportamento (viscoso para elástico) com o aumento da frequência.

A Tabela 7 mostra os valores obtidos de $\tan \delta$ para as misturas de DPPC e DPPG, com e sem Colesterol. Percebe-se que o comportamento intermediário continua presente na amostra sem Colesterol, apresentando mudança de comportamento viscoelástico ao longo da frequência e, sob frequências mais altas. Ambas amostras possuem comportamento elástico, mesmo com aumento no comportamento viscoso da amostra com Colesterol.

$D P P C: D P P G(70: 30)$

\begin{tabular}{|c|c|c|c|}
\hline Freq. (Hz) & $\mathbf{0 , 6 3}$ & $\mathbf{1 , 2 6}$ & $\mathbf{2}$ \\
\hline $\tan \delta$ & 1,98 & 0,07 & 0,47 \\
\hline
\end{tabular}

DPPC:DPPG:COL (70:20:10)

\begin{tabular}{|c|c|c|c|}
\hline Freq. $(\mathbf{H z})$ & $\mathbf{0 , 8}$ & $\mathbf{1 , 2 6}$ & $\mathbf{1 , 5 9}$ \\
\hline $\tan \delta$ & 0,98 & 0,07 & 0,14 \\
\hline
\end{tabular}

Tabela 7: $\tan \delta$ das amostras de DPPC:DPPG com e sem colesterol. 


\subsection{Determinação da viscosidade complexa $\left(\eta^{*}\right)$}

Conforme Equação 5, as viscosidades complexas puderam ser calculadas a partir dos valores de G' e G" obtidos dinamicamente com a frequência. Survanta possui viscosidade mais alta que Curosurf, que não possui Colesterol em sua composição. A adição de Colesterol à mistura DPPC:DPPG aumentou a viscosidade.

O Gráfico 13 mostra os valores obtidos da viscosidade complexa do Survanta ao longo da frequência. Neste Gráfico, nossos valores são representados por $\bullet$ e os obtidos na literatura, em frequências menores, são representados por o. Estes valores são cerca de 10 vezes maiores que os valores do Curosurf. Por isso, a aplicação de Survanta pode não ser aconselhada sob condições de alta frequência respiratória e, consequentemente, grande esforço pulmonar. Além de outros fatores não analisados neste trabalho como a presença de outros componentes, a presença de Colesterol pode ser um dos motivos da alta viscosidade.

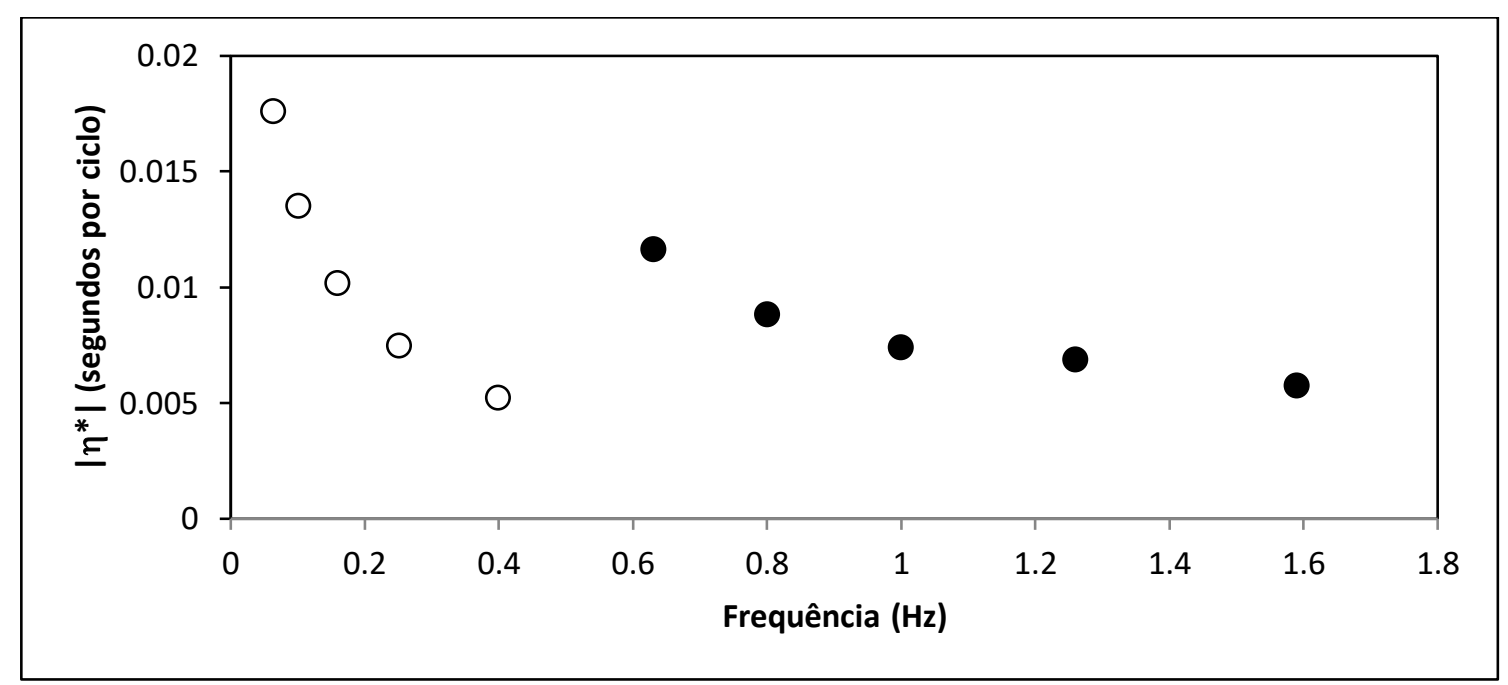

Gráfico 13: Viscosidade complexa do Survanta ao longo da frequência de interesse, com nossos dados $(\bullet)$ e da literatura $(0)$. 
A viscosidade complexa do Curosurf também foi analisada e os resultados obtidos são mostrados no Gráfico 14, cujos valores são representados por Nota-se valores mais altos sob frequências maiores, mostrando que o Curosurf se torna mais aplicável sob condições de baixo esforço respiratório. Mesmo com valores mais altos de viscosidade em maiores frequências, os resultados ainda estão bem abaixo dos apresentados pelo Survanta (Gráfico 13).

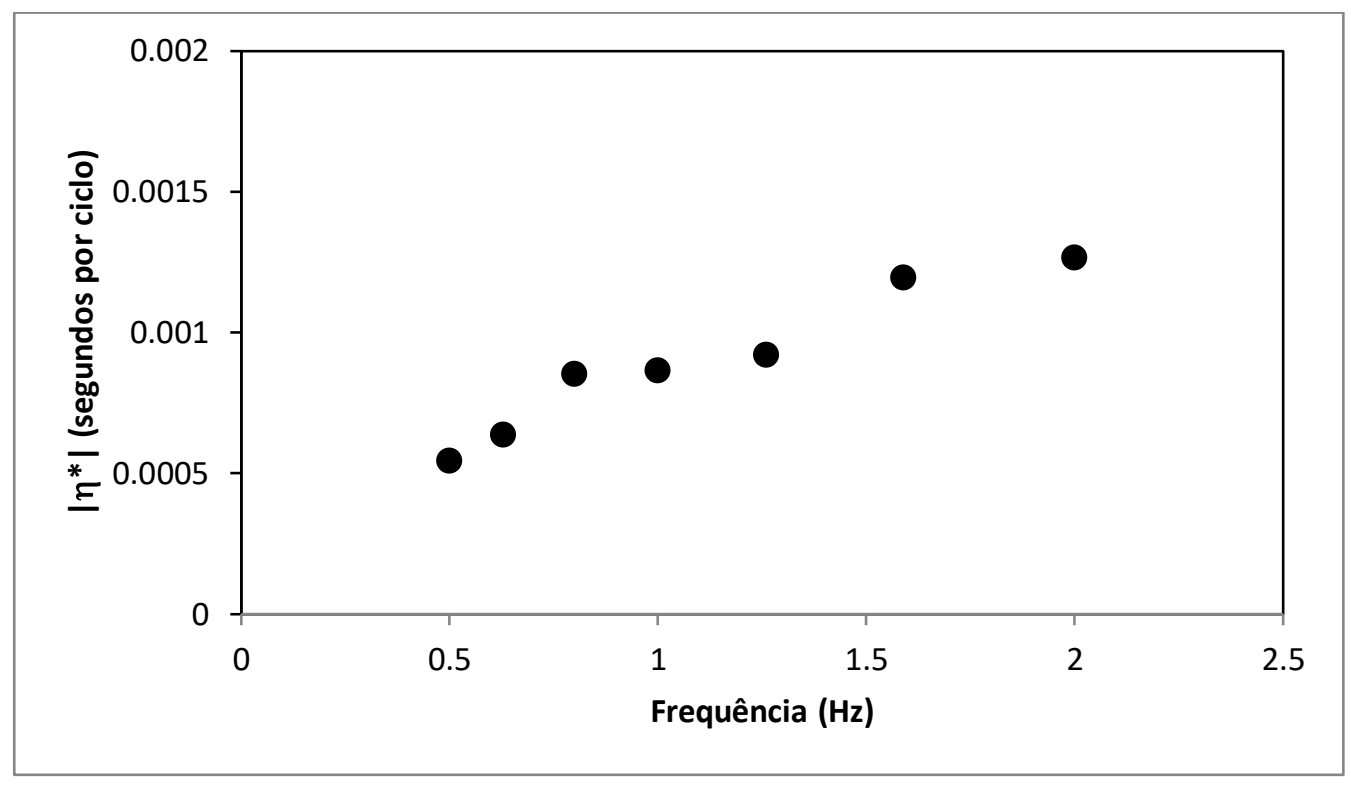

Gráfico 14: Viscosidade complexa do Curosurf.

O Gráfico 15 mostra os valores de viscosidade obtidos para a amostra de DPPC, com nossos dados experimentais (representados por $\mathbf{O}$ ) e de Hermans e colaboradores (representados por 0 ). Este Gráfico também contempla os resultados obtidos por Hermans em pressão de $20 \mathrm{mN} \cdot \mathrm{m}^{-1}$, representados por A. (HERMANS, ELINE; BHAMLA, M. S; KAO, P; FULLER, G. G; VERMANT, 2015). Relativa estabilidade na viscosidade do DPPC é percebida, tanto para frequências mais baixas, quanto para mais altas. Sugere-se que o modelo pode ser interessante em sua aplicação biológica pois o alvéolo não sofrerá mudança significativa de resistência do surfactante, independente do seu esforço respiratório. 


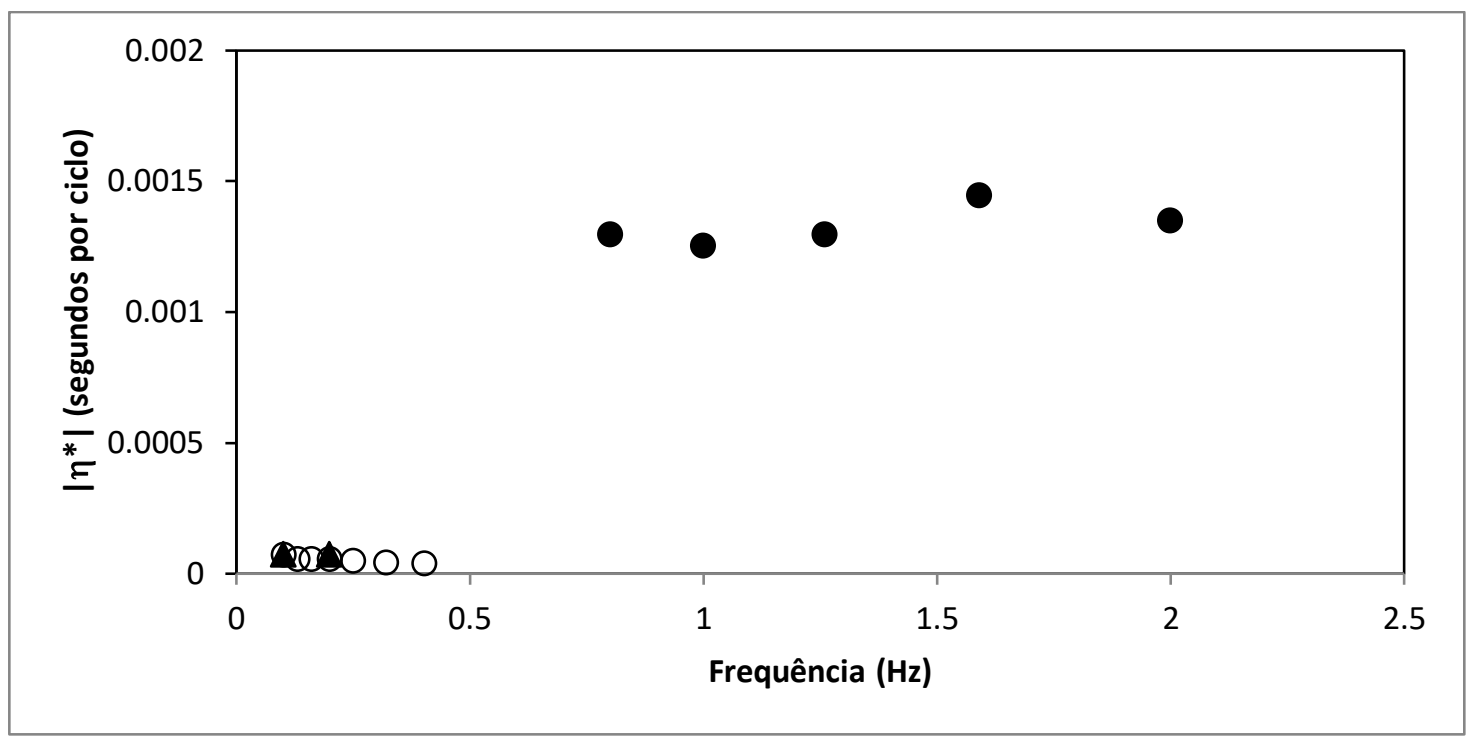

Gráfico 15: Viscosidade complexa do DPPC, com nossos dados $(\bigcirc)$ e da literatura $(\mathrm{O}$ e $\boldsymbol{\Lambda}$ ).

Os resultados obtidos na análise da viscosidade complexa das amostras de DPPC:DPPG (70:30) e DPPC:DPPG:COL (70:20:10) são mostrados no Gráfico 16, representados por • e o, respectivamente. Nota-se maior viscosidade com a presença de Colesterol, assim como no Survanta. Para estudos de surfactantes pulmonares, a amostra sem colesterol pode ser mais interessante, uma vez que se apresenta mais elástica. Os valores de viscosidade das amostras de DPPC:DPPG (70:30) e DPPC:DPPG:COL (70:20:10) apresentamse bem menores que os de Survanta.

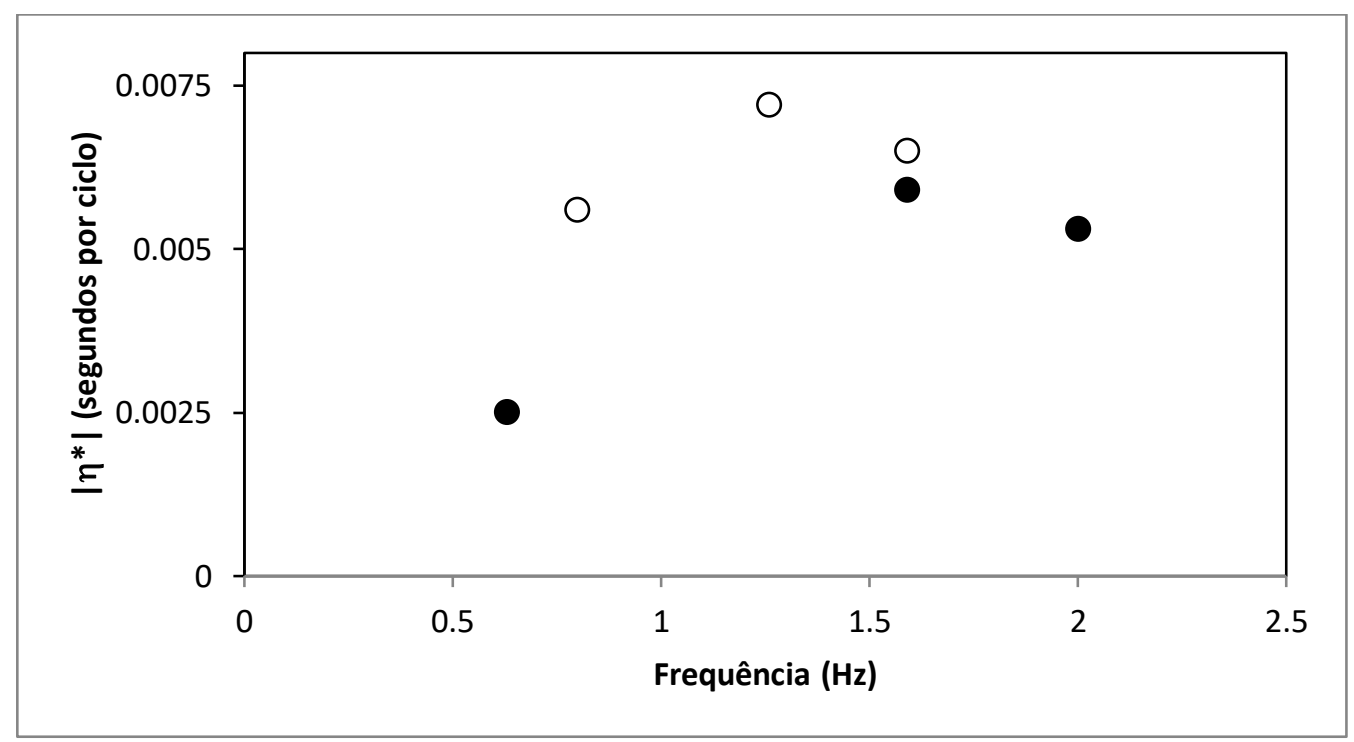

Gráfico 16: Viscosidade complexa das misturas de DPPC:DPPG (70:30) (๑) e DPPC:DPPG:Colesterol (70:20:10) (O). 


\subsection{Reologia Dilatacional}

Survanta e Curosurf foram submetidos à análise dilatacional. Porém, devido à alta viscoelasticidade destas amostras, não foi possível submeter os experimentos na frequência de interesse $(0,5 \mathrm{a} 2,0 \mathrm{~Hz})$. Os experimentos com o Survanta só atingiram a $0,1 \mathrm{~Hz}$ e não foi possível formar uma gota com volume adequado $(10 \mu \mathrm{L})$. Sendo assim, o volume máximo de $8 \mu \mathrm{L}$ foi obtido, com $10 \%$ de variação de volume para a realização da análise dilatacional. Apesar de sua relativa instabilidade, Survanta apresentou módulos elástico e viscoso estáveis na interface ar/água, como mostrado no Gráfico 17. Neste Gráfico, os valores de E' e E" são representados, respectivamente, por $\triangle \mathrm{e} \square$; já o módulo dilatacional é representado por $\boldsymbol{\Lambda}$. Survanta apresentou comportamento elástico frente à deformação dilatacional. Seu módulo dilatacional e tan $\delta$ (Gráfico 18) mostraramse estáveis ao longo do tempo em contato com ar. Apesar de ter apresentado comportamento viscoso na reologia de cisalhamento, estas informações não são necessariamente confrontáveis, pois as causas das deformações são diferentes e, consequentemente, à resposta da amostra também será, inclusive em termos de estabilidade. (GUSMÁN, EDUARDO; TAJUELO, JAVIER; PASTOR, JUAN MANUEL; RUBIO, MIGUEL ÁNGEL, ORTEGA, FRANCISCO; RUBIO, 2018).

O Curosurf, por ser mais elástico que Survanta, mostrou-se mais estável na interface ar/água sob maior frequência. Desta forma, além do experimento sob $0,1 \mathrm{~Hz}$ também foi feito sob $0,5 \mathrm{~Hz}$. Frequências maiores rompiam facilmente a gota da amostra de Curosurf. Não foi possível formar gota com volume de costume praticado no laboratório, sendo $4 \mu \mathrm{L}$ o volume máximo obtido, e variação de $8 \%$ para expansão e contração. Foram obtidos valores mais estáveis sob a frequência maior, conforme mostrados nos Gráficos 19, 20 e 21. 


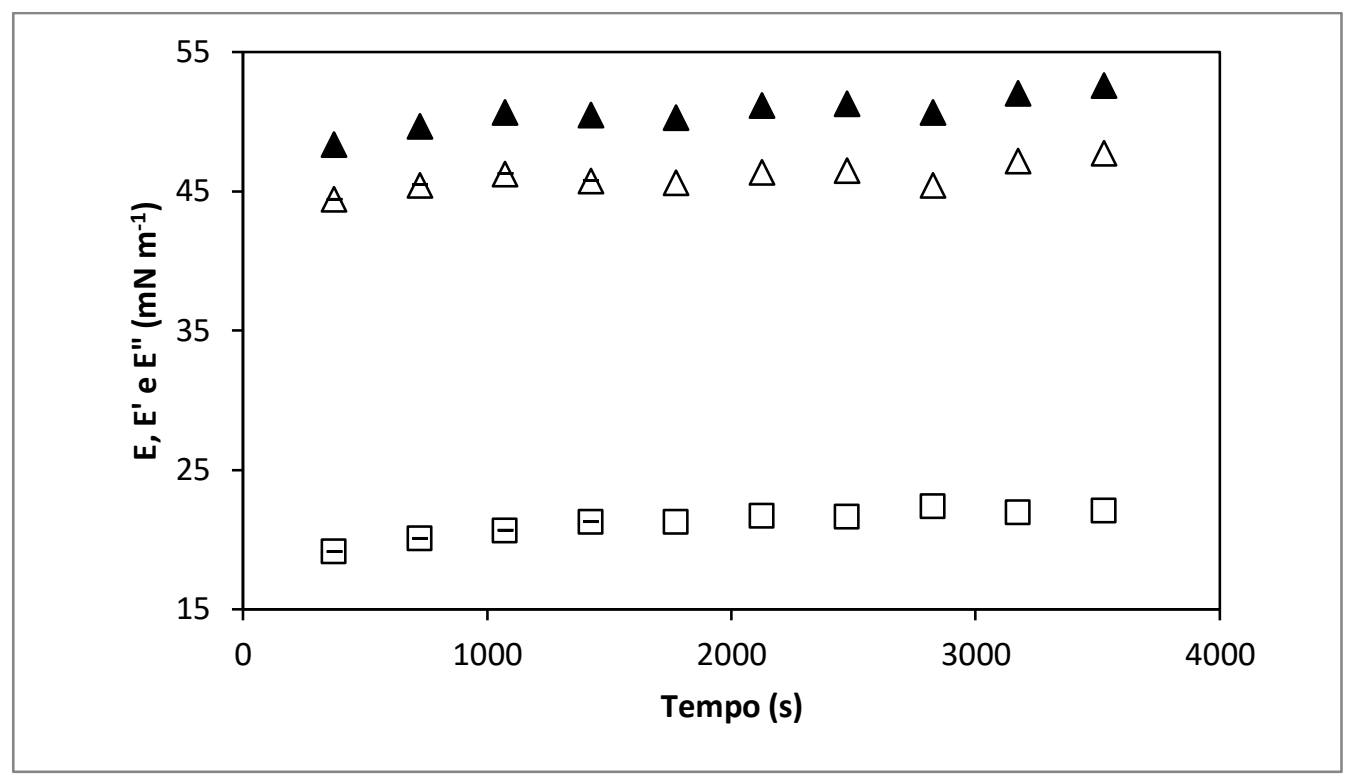

Gráfico 17: Valores de E' $(\triangle)$ e E" $(\square)$ do Survanta, com dados estáveis na interface ar/água e apresentando característica elástica e valores de $E(\boldsymbol{\Delta})$ do Survanta relativamente estáveis em função do tempo na interface ar/água.

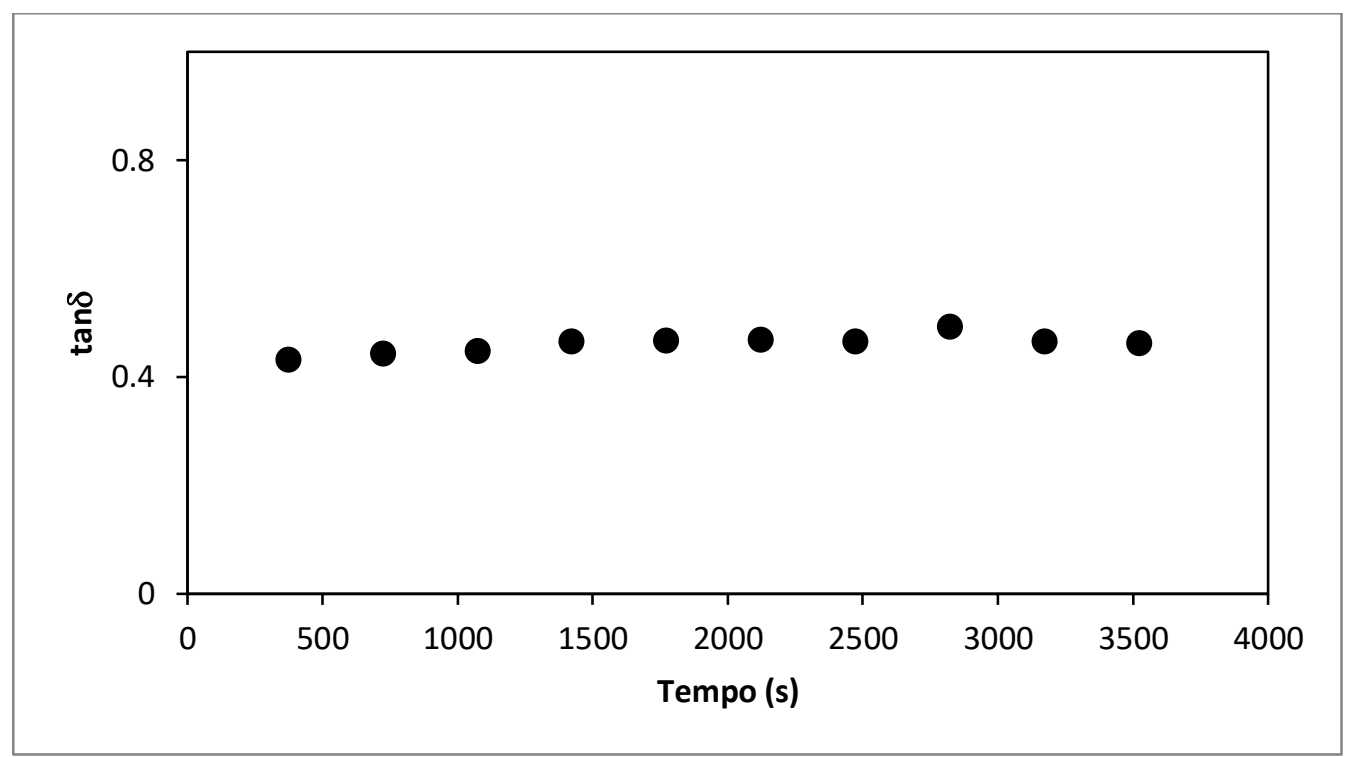

Gráfico 18: tan $\delta$ do Survanta na análise reológica dilatacional mostrando seu comportamento elástico

Os resultados obtidos para a amostra de Curosurf são mostrados no Gráfico 19, tanto em frequência de $0,1 \mathrm{~Hz}$ (cujo E' é representado por $\triangle \mathrm{e} E$ ", por $\square$ ) quanto $0,5 \mathrm{~Hz}$ (cujo E' é representado por $\boldsymbol{\Delta}$ e E”, por $\mathbf{\square}$ ). Este surfactante se mostrou mais elástico que o Survanta, apresentando maior adequabilidade à 
técnica frente nossas condições experimentais. Em ambas frequências os valores de E' e E' mostraram-se relativamente estáveis na interface, mesmo após o envelhecimento da gota (por cerca de 1 minuto). Os resultados não se apresentaram suscetíveis à mudança de frequência. Por isso, espera-se que Curosurf apresente valores parecidos de módulos elástico e viscoso mesmo sob frequências maiores. Sob a frequência maior, percebe-se maior estabilidade dos parâmetros. Assim, espera-se que o Curosurf seja um bom modelo de estudo sob frequências maiores.

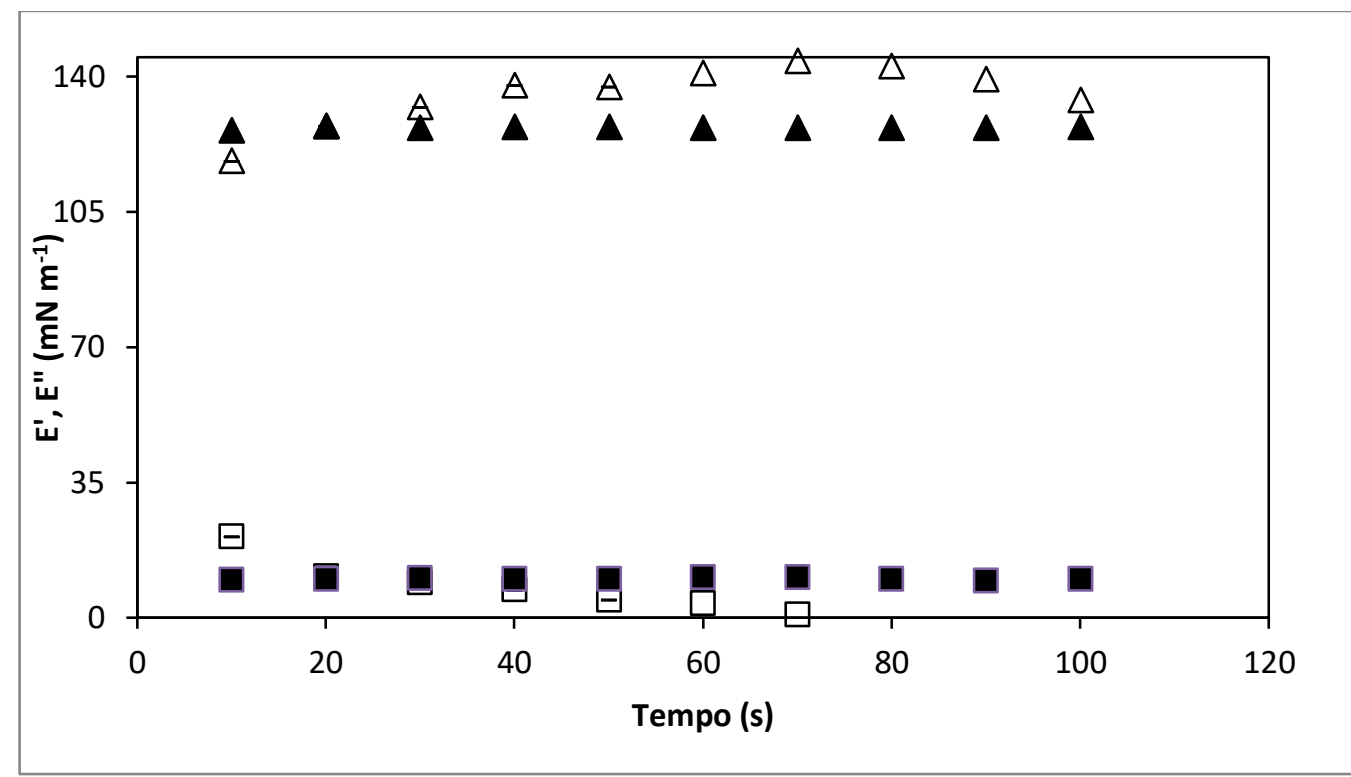

Gráfico 19: Valores de E' e E" para Curosurf sob frequências 0,1 (representados pelos símbolos vazios) e $0,5 \mathrm{~Hz}$ (representados pelos símbolos cheios). Sob a frequência maior, nota-se maior estabilidade do Curosurf, que possuía variação de volume mais rápida. Não foram obtidos valores muito discrepantes entre tais frequências.

O Gráfico 20 foi construído com os valores do módulo dilatacional do Curosurf obtidos em frequências de 0,1 (representado por $\triangle$ ) e $0,5 \mathrm{~Hz}(\mathbf{\Delta})$. Sob a frequência maior também se percebe maior estabilidade deste parâmetro ao longo do tempo. Assim, espera-se que o Curosurf seja um bom modelo de estudos frequências respiratórias mais altas, devido à manutenção de seus parâmetros reológicos. 


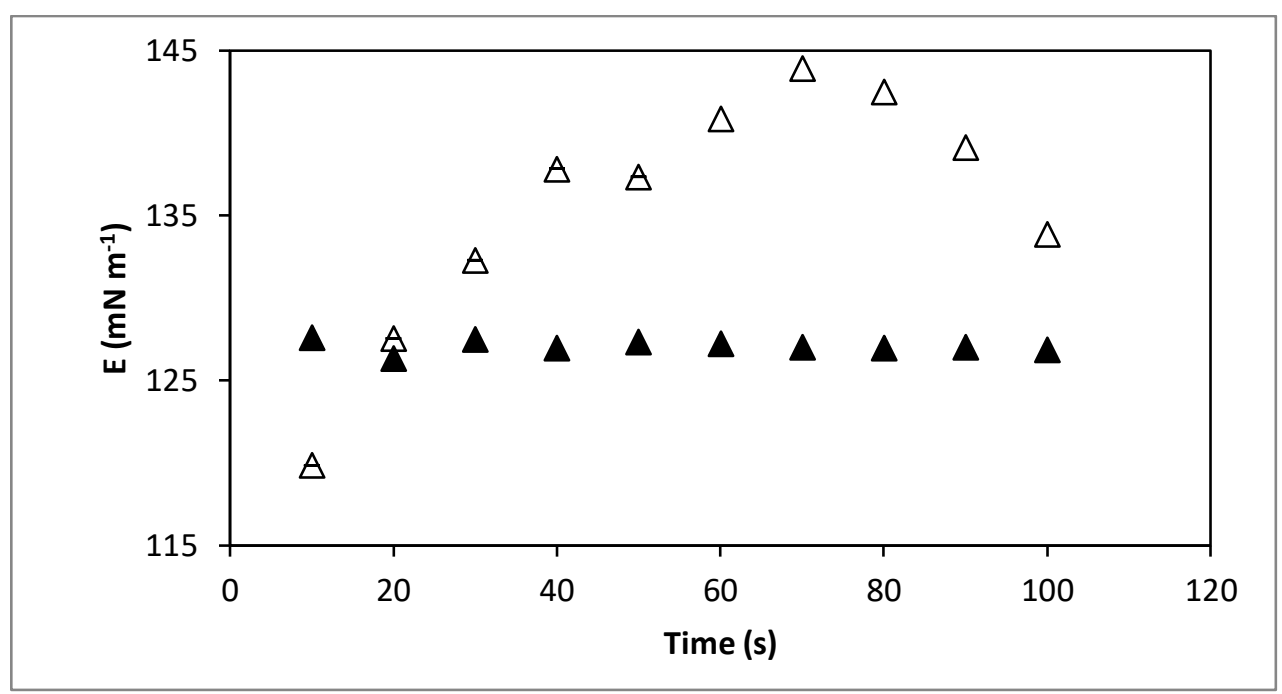

Gráfico 20: Módulo dilatacional do Curosurf em função do tempo sob frequências de $0,1(\triangle)$ e $0,5 \mathrm{~Hz}(\mathbf{\Lambda})$. Após formada a gota, esperou-se 1 minuto para as medições e sob a frequência maior, E mostrou-se mais estável.

O Gráfico 21 foi construído a partir dos valores obtidos no Gráfico 19, conforme Equação 19. Os valores de tanઈ calculados para a frequência de 0,1 $\mathrm{Hz}$ foram representados por $\mathrm{O}$, e os valores para a frequência de $0,5 \mathrm{~Hz}$, por Novamente, percebe-se maior estabilidade do parâmetro sob a frequência maior, cujos módulos E' e E" mostraram-se estáveis ao longo do tempo na interface ar/água.

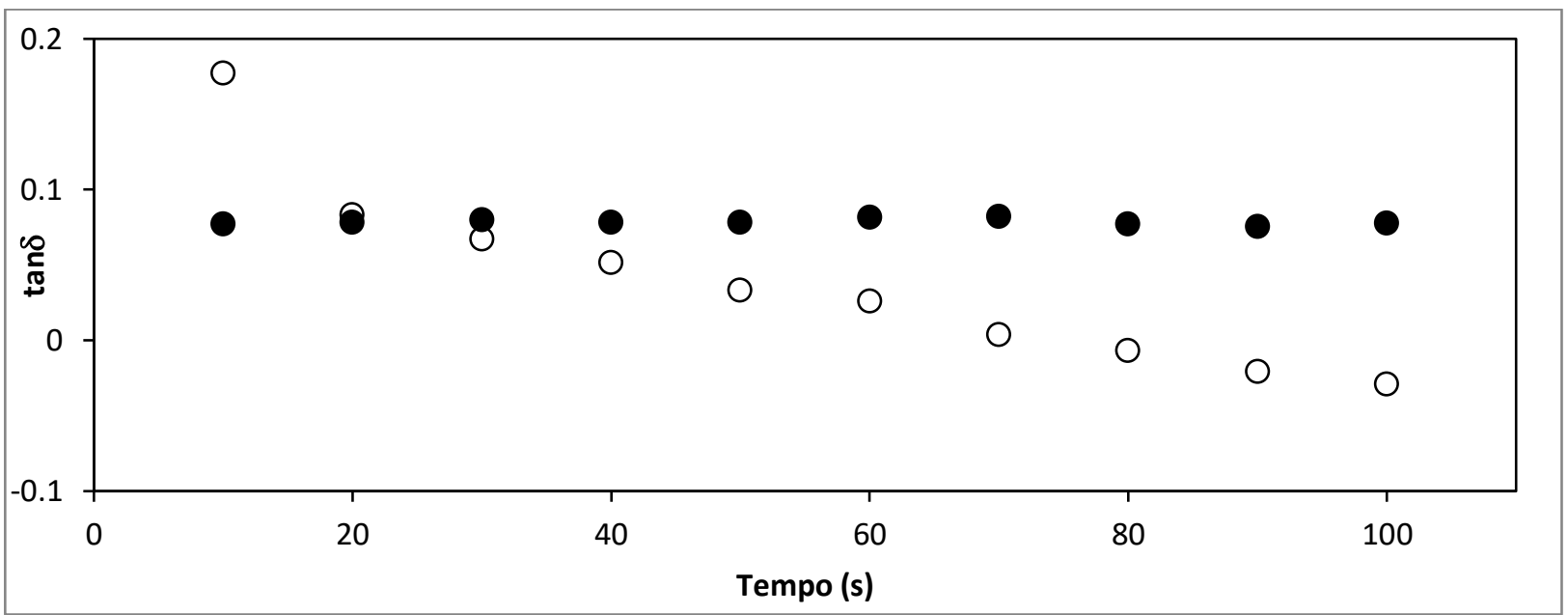

Gráfico 21: tan $\delta$ do Curosurf na reologia dilatacional, sob frequências de $0,1(\mathrm{O})$ e $0,5 \mathrm{~Hz}$ 


\section{Conclusões}

Nesta dissertação, as propriedades reológicas interfaciais dos modelos de surfactante pulmonar foram obtidas por meio das técnicas de cisalhamento (reômetro de cisalhamento interfacial) e dilatacional (tensiômetro de gota). Desta forma, os módulos elástico e viscoso (tanto de cisalhamento, quanto dilatacionais) foram obtidos e analisados, assim como a viscosidade complexa.

Os experimentos da reologia de cisalhamento foram realizados nas condições de pressão de superfície de $30 \mathrm{mN} / \mathrm{m}$ e temperatura de $28^{\circ} \mathrm{C}$. Nestas condições, Survanta apresentou comportamento viscoso, Curosurf apresentou comportamento elástico e o DPPC apresentou comportamento intermediário, sendo viscoso em baixas frequências $(<1 \mathrm{~Hz})$ e elástico em maiores frequências. A adição de DPPG ao DPPC aumentou sua elasticidade e reduziu sua viscosidade sob baixas frequências.

A influência do colesterol no modelo de surfactante pulmonar (DPPC:DPPG (70:30)) sob altas frequências também foi analisada, indicando um aumento da viscosidade da mistura. Por isso, sugere-se que o modelo simplificado DPPC:DPPG (70:30) possa ser mais interessante do que DPPC:DPPG:Colesterol (70:20:10). Em atletas, cuja frequência respiratória é alta, o colesterol pode prejudicar a atividade do surfactante pulmonar. Também, no desenvolvimento de novos modelos comerciais, é encontrado em nosso estudo que o colesterol pode ser prejudicial para o comportamento elástico do surfactante pulmonar. $O$ Gráfico da $\tan \delta$ foi construído, facilitando a visualização do comportamento das amostras ao longo da frequência e do tempo.

A viscosidade superficial das amostras foi determinada, sendo a do Survanta a maior das amostras analisadas, na faixa dos $10^{-2} \mathrm{mN} / \mathrm{m}$, enquanto Curosurf e DPPC possuem viscosidades na faixa dos $10^{-3} \mathrm{mN} / \mathrm{m}$. A adição de DPPG e Colesterol ao DPPC aumentaram a viscosidade da amostra, em especial neste último, considerando como principal no aumento da parcela viscosa nas amostras neste estudo.

A técnica do reômetro de cisalhamento interfacial mostrou-se sensível o suficiente para nossas medições, não sendo necessária nenhuma troca de geometria do sensor durante os experimentos. Porém, a técnica mostrou-se 
limitada quanto a atingir a faixa de pressão de superfície de 50 a $70 \mathrm{mN} \mathrm{m}^{-1}$, colapsando os filmes a partir de $30 \mathrm{mN} / \mathrm{m}$.

O tensiômetro de gota não se mostrou tão aplicável para estudar os surfactantes pulmonares nas condições do experimento. Tendo em vista a alta viscoelasticidade das amostras, não se pode formar a gota em volume ideal de trabalho (em torno de $10 \mu \mathrm{L}$ ) e com variação ideal de volume para o estudo (10\%), nem se variar a frequência para valores maiores que $0,5 \mathrm{~Hz}$. 


\section{$7 \quad$ Perspectivas futuras}

Como perspectivas futuras, sugere-se testar a reprodutibilidade da técnica de cisalhamento, com amostras de surfactantes pulmonares de lotes diferentes e analisar a variabilidade destas amostras. Além disso, seria interessante 0 estudo em condições mais próximas da fisiologia pulmonar (cuja pressão de superfície é entre 50 e $70 \mathrm{mN} \mathrm{m}^{-1}$ e a temperatura próxima de $36,5^{\circ} \mathrm{C}$ ).

Pela experiência do laboratório, o Survanta mostra-se mais instável que o Curosurf. Por isso, sugere-se analisar essa diferença de estabilidade com testes rotineiros. Também seria interessante estudar a reologia de cisalhamento das amostras com sensores de diferentes geometrias. 


\section{Referências}

A. A. HidAlgo, A. S. Pimentel, M. TABAK, AND O. N. OliveiRA, J. Thermodynamic and Infrared Analyses of the Interaction of Chlorpromazine with Phospholipid Monolayers. J. Phys. Chem. B, v. 110, p. 19637-19646, 2006.

AHMED, S.; AKTER, MD. S.; ROY, K.; ISLAM, M. S. Role of Surfactant for the Treatment of Alveolar Cells against Coronavirus (Covid-19). Annual Research \& Review in Biology, v. 35, n. 6, p. 34-39, 2020.

ALBERTO S. LUVIANO, JOSÉCAMPOS-TERAN, DOMINIQUE LANGEVIN, R. C.; ESPINOSA, AND G. Mechanical Properties of DPPC-POPE Mixed Langmuir Monolayers. Langmuir, v. 35, p. 16734-16744, 2019.

ALEXANDROV, N.; MARINOVA, K. G.; DANOV, K. D.; INANOV, I. B. Surface dilatational rheology measurements for oil/water systems with viscous oil. Journal of Colloid and Interface Science, v. 339, p. 545-550, 2009.

ALONSO, C.; WARING, A.; ZASADZINSKI, J. A. Keeping Lung Surfactant Where It Belongs: Protein Regulation of Two-Dimensional Viscosity. Biophysical Journal., v. 89, p. 266-273, 2005.

ARASHIRO, E. Y.; DEMARQUETTE, N. R. Use of the pendant drop method to measure interfacial tension between molten polymers. Materials Research, v. 2, p. 23-32, 1999.

BAER, B. et al. New insights into exogenous surfactant as a carrier of pulmonary therapeutics. Biochemical Pharmacology, v. 164, n. February, p. 64-73, 2019. BAILEY, W. J.; WEIR, I. S. Investigation of Methods for Direct Rheological Model Parameter Estimation. Journal of Petroleum Science and Engineering, v. 21, p. 1-13, 1998.

BAOUKINA, S.; TIELEMAN, D. P. Lung surfactant protein SP-B promotes formation of bilayer reservoirs from monolayer and lipid transfer between the interface and sub-phase. Biophysical Journal, v. 100, p. 1678-1687, 2011.

BAOUKINA, S.; TIELEMAN, D. P. Computer Simulations of Lung Surfactant. Biochimica et Biophisica Acta, v. 1858, n. 10, p. 2431-2440, 2016.

BARROY, B. R.; HILLS, B. A. A Critical Assessment of the Wilhelmy Method in Studying Lung Surfactants. J Physiol, v. 295, p. 217-227, 1979.

BENMEKBHI, M.; SÉBASTIEN, S. Limitations and Applicability of the Interfacial 
Shear Rheology in the Study of Monolayer Films at the Air-Water Interface. Journal of Dispersion Science and Technology, v. 35, p. 150-160, 2014. BENNET, C. O.; MYERS, J. E. Fenômenos de Transporte, Quantidade de Calor e Massa. [s.I.] McGraw-Hill do Brasil LTDA, 1978.

BERNHARD, W. et al. Commercial versus Native Surfactants. AM J Respir Crit Care Med, v. 162, n. 4 Pt 1, p. 1524-1533, 2000.

BLANCO, O.; PÉREZ-GIL, J. Biochemical and pharmacological differences between preparations of exogenous natural surfactant used to treat Respiratory Distress Syndrome: Role of the different components in an efficient pulmonary surfactant. European Journal of Pharmacology, v. 568, p. 1-15, 2007.

BLENCOWE, $\mathrm{H}$. et al. National, regional, and worldwide estimates of preterm birth rates in the year 2010 with time trends since 1990 for selected countries: a systematic analysis and implications. Lancet, v. 379, n. 9832, p. 2162-2172, 2012.

BROOKS, C. F. et al. An interfacial stress rheometer to study rheological transitions in monolayers at the water-air interface". Langmuir, v. 1999, n. 15, p. 2450, [s.d.].

BUHAENKO, M. R.; GOODWIN, J. W.; RICHARDSON, R. M. Surface Rheology of Spread Monolayers. Thin Solid Films, v. 159, n. 1-2, p. 171-189, 1988.

BYKOV, A. G.; MILYAEVA, O. YU.; ISAKOV, N. A. . Dynamic properties of adsorption layers of pulmonary surfactants. Influence of Matter Exchange With Bulk Phase. Colloids and Surfaces A: Physicochemical and Engineering Aspects, 2020.

CARRERA, J. M.; CABERO, L.; BARAIBAR, R. Perinatal Health in Europe: Neonatal Aspects. The Perinatal Medicine of the New Millennium, p. 1-4, 2001.

CASALS, C.; CANADAS, O. Role of Lipid Ordered/Disordered Phase Coexistence in Pulmonary Surfactant Function. Biochimica et Biophysical Acta - Biomembranes, v. 1818, n. 11, p. 2550-2562, 2012.

CHOI, S. Q. et al. Influence of Molecular Coherence on Surface Viscosity. Am Chem Society, v. 30, n. 29, p. 8829-8838, 2014.

CHRISTMANN, U. V. A. et al. Role of Lung Surfactant in Respiratory Disease: Current Knowledge in Large Animal Medicine. J Vet Inter Med, v. 23, p. 227242, 2009. 
DALTIN, D. Tensoativos: química, propriedades e aplicações. [s.l: s.n.].

DAVIS, P. J.; FLEMING, B. D.; KEOUGH, K. M. Get to Liquid-Crystalline Transition Temperatures of Water Dispersions of Two Pairs of Positional Isomers of Unsaturated Mixed-Acid Phosphatidylcholines. Biochemistry, v. 20, n. 12, p. 3633-3636, 1981.

DE LA SERNA, J. B. et al. Segregated ordered lipid phases and protein-promoted membrane cohesity are required for pulmonary surfactant films to stabilize and protect the respiratory surface. Faraday Discussions, v. 161, p. 535-548, 2012. DUNCAN, S. L.; LARSON, R. G. Folding of lipid monolayer containing lung surfactant proteins SP-B and SP-C studied via coarse-grained molecular dynamics simulation. Biochimica and Biophysica Acta (BBA) Biomembranes, v. 1798, n. 9, p. 1632-1650, 2010.

EERP/USP. Capacitação Parada Cardiorrespiratória Adulto. Disponível em: <http://www2.eerp.usp.br/Nepien/PCR/res_componentes.html>. Acesso em: 13 jun. 2020.

ENHÖRNING, G.; ROBERTSON, B. Lung expansion in the premature newborn rabbit fetus after tracheal deposition of surfactant. Pediatrics, v. 50, n. 1, p. 5866, 1972.

ERNI, P.; FISCHER, P.; WINDHAB, E. J. Stress and Strain Controlled Measurements of Interfacial Shear Viscosity and viscoelasticity at liquid/liquid and gas/liquid interfaces. Rev Sci Instrum, v. 74, n. 11, p. 4916-4924, 2003.

FILHO, P. L. O; GERBELLI, B. B., FORNASIER, F.; FILHO, A. B. C; YOSHINAGA, M. Y; MIYAMOTO, S; MORTARA, L; LACERDA, C. D; CUCCOVIA, I. M; PIMENTEL, A. S; OLIVEIRA, C. L. P. Structure and Thermotropic Behavior of Bovine- and Porcine- Derived Exonegous Lung Surfactants. Langmuir, 2020.

FORNAZIER, C. et al. Abordagem de Vigilância Sanitária de Produtor para Saúde Comercializados no Brasil: Ventilador Pulmonar. BIT, n. 3, 2011.

FREDDI, N. A; FILHO, J, O; FIORI, H, H. Terapia com surfactante pulmonar exógeno em pediatria. J. Pediatr., v. 79, n. 2, p. S205-S212, 2003.

GAZITÚA, R. Manual de semiologia. 2014

GEHR, P. B. M. W. E. The normal human lung: ultrastructure and morphometric estimation of diffusion capacity. Respiratory Physiology, v. 32, n. 2, p. 121140, 1978. 
GOERKE, J. Pulmonary Surfactant: Functions and molecular composition. Biochimica et Biophysica Acta-Molecular Basis of Disease, v. 1408, n. 2, p. 79-89, 1998.

GOODRICH, F. C.; ALLEN, L. H.; POSKANZER, A. A new surface viscometer of high sensivity. Journal of Colloid and Interface Science, v. 52, n. 2, p. 201212, 1975.

GUSMÁN, EDUARDO; TAJUELO, JAVIER; PASTOR, JUAN MANUEL; RUBIO, MIGUEL ÁNGEL, ORTEGA, FRANCISCO; RUBIO, R. G. Shear rheology of fluid interfaces: Closing the gap between macro- and micro-rheology. Elsevier, v. 37, p. 33-48, 2018.

HALLIDAY, H. L. Surfactants: past, present and future. Journal of Perinatalogy, v. 28, p. S47-S56, 2008.

HERMANS, ELINE; BHAMLA, M. S; KAO, P; FULLER, G. G; VERMANT, J. Lung surfactants and different contributions to thin film stability. Royal Society of Chemistry, 2015.

HERMANS, E. et al. Lung surfactants and different contributions to thin film stability. Royal Society of Chemistry, v. 11, p. 8048-8057, 2015.

HERMANS, E.; VERMANT, J. Interfacial Shear Rheology of DPPC under physiologically relevant conditions. Royal Society of Chemistry, v. 10, p. 175186, 2014.

HILLS, B. A. An alternative view of the role (s) of surfactant and the alveolar model. Journal of Applied Physiology, v. 8, p. 1567-1583, 1999.

IVANOVA, TZ.; MINKOV, I.; PANAIOTOV, I.; SAULNIER, P.; PROUST, J. E. Dilatacional properties and morphology of surface films spread from clinically used lung surfactants. Colloid Polym Sci, v. 282, p. 1258-1267, 2004.

JM, C.; CABERO, L.; BARAIBAR R. Perinatal Health in Latin América. The Perinatal Medicine of the New Millennium, p. 19-24, 2001.

KRAGEL, J. et al. Surface Viscoelasticity of Phospholipid Monolayers at the Air/Water Interface. Colloid Polym Sci, v. 274, p. 1183-1187, 1996.

LANGENVIN, D. Surface shear rheology of monolayers at the surface of water. Advances in Colloid and Interface Science, v. 207, p. 121-130, 2014.

LAWN, J. E. et al. Why are 4 million newborn babies dying each year? Lancet, v. 364, n. 9432, p. 399-401, 2004.

LI, J. B.; KRETZSCHMAR, G.; MILLER, R.; MOHWALD, H. Viscoelasticity of 
phospholipid layers at different fluid interfaces. Colloids and Surfaces A, p. 491-497, 1999.

LI, S. P.; ZHAO, G.; CHEN, H. Y. The Relationship between Steady Shear Viscosity and Complex Viscosity. Journal of Dispersion Science and Technology, v. 26, p. 415-419, 2005.

LINDH, W, Q; POOLER, M; TAMPARO, C. D; DAHL, B. M. Delmar's Comprehensive Medical Assisting: Administrative and Clinical Competencies. [s.I.] Cengange Learning, 2009.

LIPPINCOTT WILLIAMS; WILKINS. Exercise Physiology: Energy, Nutricion and Human Physiology. [s.l: s.n.].

LIU, L. et al. Global, regional, and national causes of under-5 mortality in 200015: an updated systematic analysis with implications for the Sustainable Development Goals. The Lancet, v. 388, p. 3027-3035, 2016.

LOCCI, G. et al. Hyaline Membrane Disease (HMD): The Role of the Perinatal Pathologist. Journal of Pediatric and Neonatal Individualized Medicine, v. V, p. 1-9, 2014.

MEYERS, MARE; CHAWLA, K. Mechanical behavior of materials. 2a. ed. [s.I.] Cabrigde University Press, 2009.

MILLER, R; FERRI, J. K; JAVADI, A. Rheology of interfacial layers. Colloid Polym Sci, v. 288, p. 937-950, 2010.

MINGARRO, I. et al. Synthetic Pulmonary Surfactant Preparations: New Developments and Future Trends. Current Medicinal Chemistry, v. 15, p. 393403, 2008.

MIRKA KORHONEN; LEENA HELLEN; JOUNI HIRVONEN, J. Y. Rheological properties of creams with four different surfactant combinations - effect of storage time and conditions. International journal of pharmaceutics, v. 221, p. 187196, 2001.

MONSEN, A. C.; BAGATOLLI, L. A. Cholesterol rules - Direct observation of the coexistence of two fluid phases in native pulmonary surfactant membranes at physiological temperatures. Journal of Biological Chemistry, v. 279, n. 39, p. 40715-40722, 2004.

MORRIS, V. J. Proceedings of 3rd International Symposium on Food Rheology and Structure. p. 417, 2003.

NAG, K. et al. Epifluorescence microscopic observation of monolayers of $d$ 
ipalmitoylphosphatidylcholine - dependence of domain size on compression rates. Biochimica Et Biophysica Acta, v. 1068, n. 2, p. 157-160, 1991.

NAG, K. et al. SP-B refining of pulmonary surfactant phospholipid films. American Journal of Physiology - Lung Cellular and Molecular Physiology, v. 277, p. L1179-L1189, 1999.

OLMEDA, B.; GARCÍA-ÁLVAREZ, B.; PÉREZ-GIL, J. Structure-function correlations of pulmonary surfactant protein SP-B and the saposin-like family of proteins. Eur. Biophys, p. 1-14, 2012.

PANDA, A. K. et al. Effect of acute lung injury on structure and function of pulmonary surfactant films. Am J Respir Cell Mol Biol, v. 30, n. 5, p. 641-650, 2003.

PARRA, E.; PÉREZ-GIL, J. Composition, structure and mechanical properties define performance of pulmonary surfactant membranes and films. Chemistry and Physics of Lipids, v. 185, p. 153-175, 2015.

PÉREZ-GIL, J. et al. Interfacial Adsorption of simple lipid mixtures combined with hydrophobic surfactant protein from pig lung. Biochem. Cell Biol, v. 70, p. 332338, 1992.

PÉREZ-GIL, J. Structure of Pulmonary Surfactant Membranes and Films: The Role of Proteins and Lipid-Proteins Interactions. Biochimica et Biophysica Acta - Biomembranes, v. 1778, n. 7, p. 1676-1695, 2008.

PÉREZ-GIL, J.; CASALS, C.; MARSH, D. Interactions of hydrophobic lung surfactant proteins SP-B and SP-C with dipalmitoylphosphatidylcholine and dipalmitoylphosphatidylglycerol bilayers studied by Electron Spin Resonance Spectroscopy. Biochemistry, v. 34, p. 3964-3971, 1995.

POLIN, R. A.; CARLO, W. A. Surfactant-Replacement Therapy for Respiratory Distress in the Preterm and Term Neonate. American Academy of Pediatrics., v. 121, p. 419-432, 2008.

PULMOLOGY, H. Synthetic lung surfactant inhalation improves bronchial asthma.

Disponível

em:

$<$ https://www.healio.com/news/pulmonology/20191125/synthetic-lung-

surfactant-inhalation-improves-bronchial-asthma>. Acesso em: 22 ago. 2020.

RAMANATHAN, R. et al. A Randomized, Multicenter Masked Comparison Trial of Poractant Alfa (Curosurf) versus Beractant (Survanta) in the Treatment of Respiratory Distress Syndrome in Pretern Infants. Am J Perinatol, v. 21, n. 3, p. 
109-19, 2004.

RAO, M. A. Measurement of viscoelastic properties of fluid and semisolid food. New York: Elsevier Applied Science, p. 207-231, 1992.

RAVERA, F; LOGLIO, G; KOVALCHUK, V. I. Interfacial dilational rheology by oscillating bubble/drop methods. Current Opinion in Colloid \& Interface Science, v. 15, p. 217-228, 2010.

REBELLO, C. M. et al. Terapia com Surfactante Pulmonar Exógeno - O que é estabelecido e o que necessitamos determinar. jornal de Pediatria., v. 78, n. 2, p. S215-S226, 2002.

ROBERTSON, B.; ENHÖRNING, G. The alveolar lining of the premature newborn rabbit after pharyngeal deposition of surfactant. Lab Invest, v. 34, p. 54-59, 1974.

RODRÍGUEZ-MOLINERO, A; NARVAIZA, L; RUIZ, J; GÁLVEZ-BARRÓN, C. Normal respiratory rate and peripheral blood oxygen saturation in the elderly population. Journal of the American Geriatrics Society, v. 61, n. 12, p. 22382240, 2013.

RODRIGUEZ, E. L.; PÉREZ-GIL, J. Structure-function relationships in pulmonary surfactant membranes: From biophysics to therapy. Biochimica et Biophysica Acta, v. 1838, n. 6, p. 1568-1585, 2014.

ROSSINI, C. V. T.; MOLINA, C.; CASELI, L. Langmuir and Langmuir-Blodgett films of di-ureasil hybrid compounds containing phosphotungstic acid. Colloids and Surfaces A, v. 524, p. 35-42, 2017.

RUDIGER, M. et al. Naturally Derived Commercial Surfactants Differ in Composition of Surfactant Lipids and Surface Viscosity. Am J Physiol Lung Cell Mol Physiol, v. 288, p. L379-L383, 2005.

SÁNCHEZ-PUGA, P. et al. Dynamic Measurements with the Bicone Interfacial Shear Rheometer: Numerical Benchmarking of Flow Field-Based Data Processing. Colloids Interfaces, v. 2, n. 4, p. 69, 2018.

SCHLEGELMILCH, M. P. Considerations for the use and study of exogenous surfactant in respiratory disease from COVID-19. Canadian Journal of Respiratory, p. 1-3, 2020.

SCHRAMM, G. Reologia e Reometria: Fundamentos teóricos e práticos. São Paulo: ed. [s.l: s.n.].

SCHUER, JULIA J; ARNDT, ALEXEJ; WOLK, CHRISTIAN, PINNAPIREDDY, 
SHASHANK, R; BAKOWSKY, U. Establishment of a Synthetic In Vitro Lung Surfactant Model for Particle Interaction Studies on a Langmuir Film Balance. Langmuir, v. 36, p. 4808-4819, 2020.

SEEHASE, M. et al. New Surfactant with SP-B and C Analogs Gives Survival Benefit After Inactivation in Preterm Lambs. Plos One, v. 7, n. 10, p. 1-10, 2012. SELLADURAI, S. L. et al. Model Lung Surfactant Films: Why Composition Matters. Langmuir, v. 32, n. 41, p. 10767-10775, 2016.

SHU-PING LI; GE ZHAO; HONG-YUAN. The relationship between steady shear viscosity and complex viscosity. Journal of Dispersion Science and Technology, v. 26, n. 4, p. 415-419, 2006.

STONE, H. A. Fluid motion of monomolecular films in a channel flow geometry. Physics of Fluids, v. 7, p. 2931-2937, 1995.

SWABE, A. et al. Pulmonary Surfactant Secretion Is Regulated by the Physical State of Extracellular Phosphatidylcholine. Journal of Biological Chemistry, v. 267, n. 28, p. 19884-19890, 1992.

TADROS, T. Application of rheology for assessment and prediction of the longterm physical stability of emulsion. Advances in Colloid and Interface Science, v. 108, p. 227-258, 2005.

VELDHUIZEN, R. A. W.; ZUO, Y. Y.; PETERSEN, N. O.; LEWIS, J. F.; POSSMAYER, F. The COVID-19 pandemic: a target for surfactant therapy? Expert Review of Respiratory Medicine, 2020.

VELDHUIZEN, R. et al. The Role of Lipids in Pulmonary Surfactant. Biochimica et Biophysica Acta, v. 1408, p. 90-108, 1998.

VERWIJLEN, T. et al. Study of the Flow Field in the Magnetic Rod Interfacial Stress Rheometer. Langmuir, v. 27, p. 9345-9358, 2011.

WEIBEL. Morphometry of the Human Lung. [s.I.] Academic Press: New York, 1963.

WEIBEL. Morphological basis of alveolar-capillary gas exchange. Physiological Reviews, v. 53, p. 419-495, 1973.

WORTHMAN, L. A. et al. Cholesterol in Condensed and Fluid Phosphatidylcholine Monolayers Studied by Epifluorescence Microscopy. Biophysical Journal, v. 76, n. 6, p. 2569-2580, 1997.

ZHANG, H. et al. Comparative Study of Clinical Pulmonary Surfactants Using Atomic Force Microscopy. Biochimica et Biophysics Acta, v. 1808, p. 1832- 
1842, 2011.

ZHANG, Y. L.; MATAR, O. K.; CRASTER, R. V. Surfactant Spreading on a Thing Weakly Viscoelastic Film. J Nom-Newtonian Fluid Mech, v. 105, p. 53-78, 2002.

ZUO, Y. et al. Current Perspectives in pulmonary surfactant-inhibition, enhancement and evaluation. Biochimica et Biophysica Acta, v. 1778, p. 1947-1977, 2008. 